\title{
British
}

\section{Gold potential of the Dalradian rocks of north-west Northern Ireland: prospectivity analysis using Tellus data}

Internal Report OR/08/039

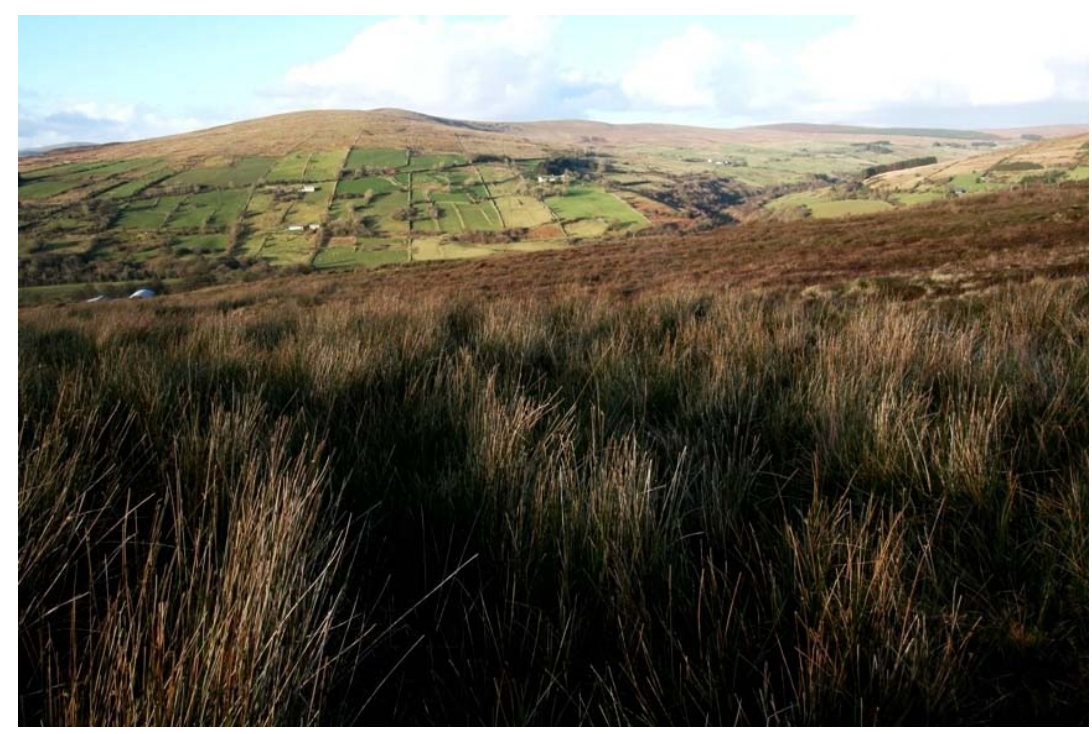





\section{Gold potential of the Dalradian rocks of north-west Northern Ireland: prospectivity analysis using Tellus data}

Keywords

Northern Ireland, prospectivity analysis, gold

Front cover

The Owenkillew Valley, Tyrone, Northern Ireland (Photo: P. McDonnell)

Bibliographical reference

PAJ LUSTY, PM MCDONNELL, AG GUNN, BC CHACKSFIELD AND M COOPER. 2009. Gold potential of the Dalradian rocks of NW Northern Ireland: prospectivity analysis using

Tellus data. British Geological

Survey Internal Report,

OR/08/39. 74pp.

Copyright in materials derived from the British Geological

Survey's work is owned by the Natural Environment Research Council (NERC) and/or the authority that commissioned the work. You may not copy or adapt this publication without first obtaining permission. Contact the BGS Intellectual Property Rights Section, British Geological Survey, Keyworth,

e-mail ipr@bgs.ac.uk. You may quote extracts of a reasonable

length without prior permission, provided a full acknowledgement is given of the source of the extract.

Maps and diagrams in this book use topography based on

Ordnance Survey mapping.
PAJ Lusty, PM McDonnell, AG Gunn BC Chacksfield and M Cooper 


\section{BRITISH GEOLOGICAL SURVEY}

The full range of our publications is available from BGS shops at Nottingham, Edinburgh, London and Cardiff (Welsh publications only) see contact details below or shop online at www.geologyshop.com

The London Information Office also maintains a reference collection of BGS publications, including maps, for consultation.

We publish an annual catalogue of our maps and other publications; this catalogue is available online or from any of the BGS shops.

The British Geological Survey carries out the geological survey of Great Britain and Northern Ireland (the latter as an agency service for the government of Northern Ireland), and of the surrounding continental shelf, as well as basic research projects. It also undertakes programmes of technical aid in geology in developing countries.

The British Geological Survey is a component body of the Natural Environment Research Council.
British Geological Survey offices

BGS Central Enquiries Desk

Tel 01159363143

Fax 01159363276

email enquiries@bgs.ac.uk

Kingsley Dunham Centre, Keyworth, Nottingham NG12 5GG

Tel 01159363241

Fax 01159363488

email sales@bgs.ac.uk

Murchison House, West Mains Road, Edinburgh EH9 3LA

Tel 01316671000

Fax 01316682683

email scotsales@bgs.ac.uk

London Information Office at the Natural History Museum (Earth Galleries), Exhibition Road, South Kensington, London SW7 2DE

Tel $02075894090 \quad$ Fax 02075848270

Tel 0207942 5344/45 email bgslondon@bgs.ac.uk

Columbus House, Greenmeadow Springs, Tongwynlais, Cardiff CF15 7NE

Tel $02920521962 \quad$ Fax 02920521963

Forde House, Park Five Business Centre, Harrier Way, Sowton EX2 7HU

Tel 01392445271

Fax 01392445371

Maclean Building, Crowmarsh Gifford, Wallingford OX10 8BB

Tel 01491838800

Fax 01491692345

Geological Survey of Northern Ireland, Colby House, Stranmillis Court, Belfast BT9 5BF

Tel 02890388462

Fax 02890388461

www.bgs.ac.uk/gsni/

Parent Body

Natural Environment Research Council, Polaris House, North Star Avenue, Swindon SN2 1EU

Tel 01793411500

Fax 01793411501

www.nerc.ac.uk

Website www.bgs.ac.uk

Shop online at www.geologyshop.com 


\section{Acknowledgements}

The authors are indebted to the staff of GSNI, in particular those who worked on the Tellus project, for their assistance in providing data and expertise, and for discussion of the results of this study. Garth Earls, Director GSNI, provided expert information and advice on gold in the Dalradian rocks of Northern Ireland and made many suggestions to improve this and future studies. 


\section{Contents}

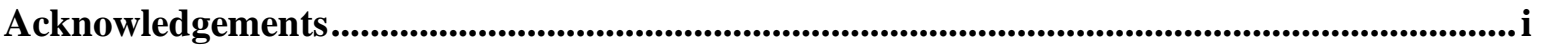

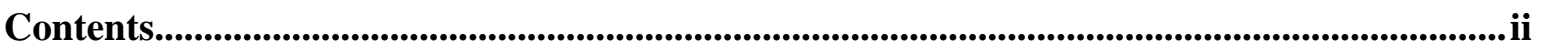

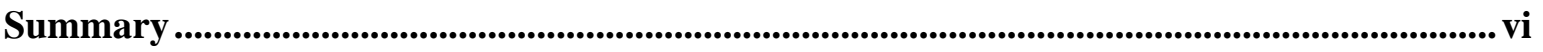

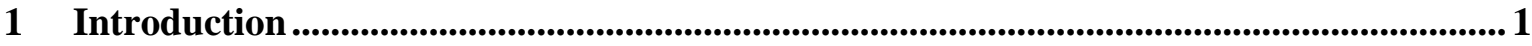

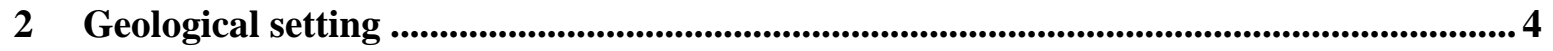

2.1 Geology of the Newtownstewart sheet .................................................................. 4

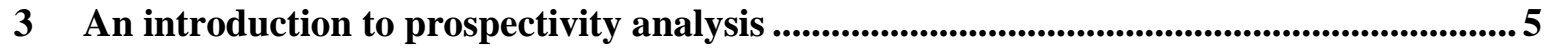

Mineral deposit models and key exploration criteria ....................................................................... 7

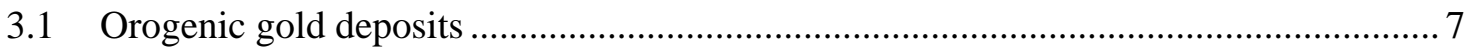

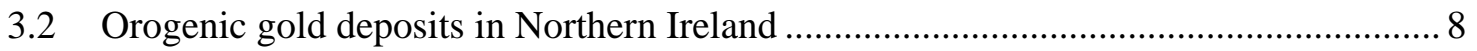

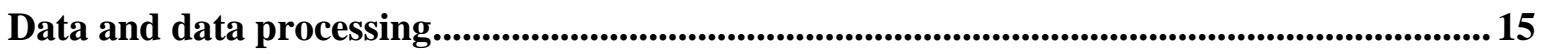

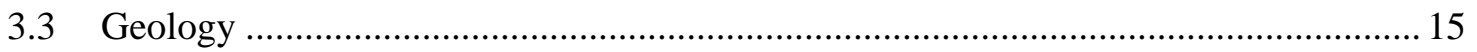

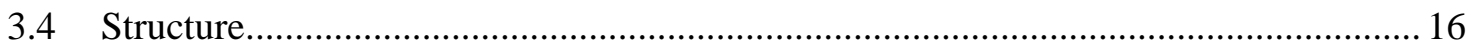

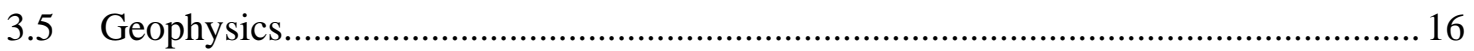

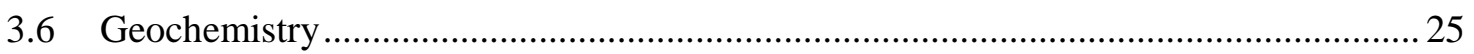

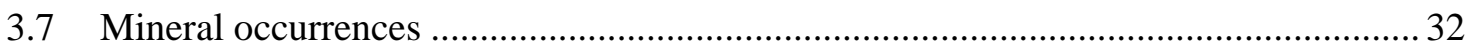

4 Application of Fuzzy Logic modelling to the study area ................................................. 32

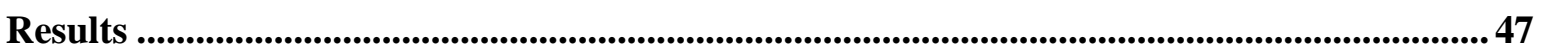

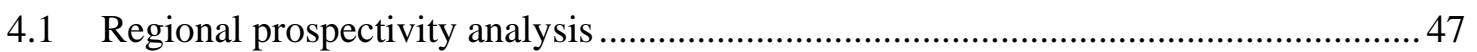

4.2 Detailed prospectivity analysis of the Newtownstewart sheet ................................... 54

4.3 The effect of assigning intra-Dalradian rankings .................................................. 56

5 Discussion and conclusions..................................................................................................69

6 Recommendations for further work ........................................................................................... 71

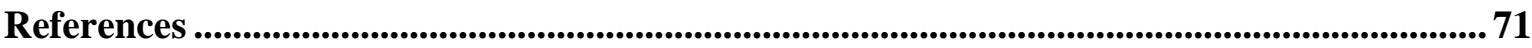

\section{FIGURES}

Figure 1 Major Caledonian structures and the location of significant gold deposits in Britain and Ireland. DL, Donegal Lineament; OL, Omagh Lineament; CB, Cregganbaun; CP, Croagh Patrick, CV, Cavanacaw, CT, Curraghinalt; CL, Clontibret, GH, Glenhead; L, Leadhills; CN, Cononish; CL, Calliacher-Urlar Burn (Adapted from Parnell et al. 2000). ...............1

Figure 2 The distribution of exploration and mining licences in Northern Ireland, March 2008. A cluster of licences is present over the Dalradian rocks of the Sperrin Mountains (shown by the red outline). 
Figure 3 The location of the study area and the main gold deposits. The Newtownstewart map sheet area, selected for detailed analysis, is outlined by the dashed line.

Figure 4 Geology of the Newtownstewart sheet (GSNI, 2007) ............................................ 6

Figure 5 The location of the Curraghinalt and Cavanacaw deposits and other occurrences of

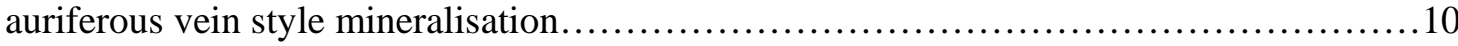

Figure 6 Generalised geology of the study area showing the groupings used in the prospectivity analysis. 17

Figure 7 Reduced to pole magnetic anomaly map. 18

Figure 8 Magnetic pseudogravity horizontal gradient anomaly map. 19

Figure 9 Electromagnetic field apparent resistivity anomaly map............................................ 20

Figure 10 Residual Bouguer gravity anomaly map 21

Figure 11 Digitised lineaments derived from the Tellus geophysical survey and the regional gravity dataset for the regional scale analysis. 22

Figure 12 Lineaments derived from the Tellus geophysical data over the Newtownstewart map sheet.

Figure 13 The distribution of gold in Tellus stream-sediment samples...................................... 26

Figure 14 The distribution of silver in Tellus stream-sediment samples. ................................... 27

Figure 15 The distribution of arsenic in Tellus stream-sediment samples.................................. 28

Figure 16 The distribution of copper in Tellus stream-sediment samples. ................................. 29

Figure 17 The distribution of lead in Tellus stream-sediment samples. ...................................... 30

Figure 18 The distribution of zinc in Tellus stream-sediment samples. ..................................... 31

Figure 19 Allocation of Fuzzy membership values to Dalradian Formations. ............................ 35

Figure 20 Buffered north-east-trending structures. ..................................................................... 39

Figure 21 Buffered north-south-trending structures............................................................. 40

Figure 22 Buffered east- to east-south-east-trending structures..................................................... 41

Figure 23 Buffered east-north-east-trending structures. ........................................................... 42

Figure 24 Buffered south-south-east-trending structures........................................................ 43

Figure 25 Buffered regional structures................................................................................. 44

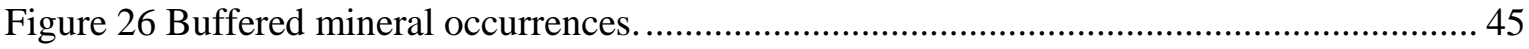

Figure 27 Buffered Tellus panned gold occurrences. ............................................................ 46

Figure 28 Schematic Fuzzy Logic model used for the Dalradian rocks of NW Northern Ireland (Cr - Curraghinalt model; Cv - Cavanacaw model), primary datasets are shown in boxes with thicker outlines and datasets only applicable to a single model are displayed in red............ 47

Figure 29 The distribution of prospectivity for orogenic gold mineralisation based on the Curraghinalt regional model (simplified geological theme).

Figure 30 The distribution of prospectivity for orogenic gold mineralisation based on the Cavanacaw regional model (simplified geological theme).

Figure 31 Curraghinalt model detailed prospectivity analysis results (simplified geological theme).

Figure 32 Cavanacaw model detailed prospectivity analysis results (simplified geological theme). 
Figure 33 Curraghinalt model regional prospectivity analysis results displayed over Newtownstewart 1:50 000 scale geology (simplified geological theme).

Figure 34 Cavanacaw model regional prospectivity analysis results displayed over Newtownstewart 1:50 000 scale geology (simplified geological theme).

Figure 35 Curraghinalt model regional prospectivity analysis results incorporating V1 geology theme.

Figure 36 Cavanacaw model regional prospectivity analysis results incorporating V1 geology theme.

Figure 37 Curraghinalt model detailed prospectivity analysis results incorporating V1 geology theme.

Figure 38 Cavanacaw model detailed prospectivity analysis results incorporating V1 geology theme.

Figure 39 Curraghinalt model regional prospectivity analysis results incorporating V2 geology theme.

Figure 40 Cavanacaw model regional prospectivity analysis results incorporating V2 geology theme.

Figure 41 Curraghinalt model detailed prospectivity analysis results incorporating V2 geology theme.

Figure 42 Cavanacaw model detailed prospectivity analysis results incorporating V2 geology theme.

\section{TABLES}

Table 1 Key exploration criteria for Phanerozoic orogenic vein gold mineralisation and their occurrence in the study area (criteria compiled from: ${ }^{1}$ Birerlein and Crowe (2000); ${ }^{2}$ Ash et al. (1996); ${ }^{3}$ Nesbitt (1993); ${ }^{4}$ Earls et al. (1996b)).

Table 2 Key exploration criteria for vein gold mineralisation in Northern Ireland $\left({ }^{1}\right.$ Earls et al. (1996b)).

Table 3 The significance assigned to regional structures, other structural vectors and geochemical criteria in the two prospectivity models used in this study, referred to as the Curraghinalt and Cavanacaw models.

Table 4 Relative ranking of Dalradian Formations in the Sperrins based upon favourability for hosting gold mineralisation ( $10=$ highest favourability) (Garth Earls pers. comm.)............ 15

Table 5 Summary statistics for selected elements in Tellus stream-sediment samples for the study area. All values in ppm, except Au in ppb.

Table 6 Fuzzy membership values assigned to the simplified geology data theme in the initial modelling.

Table 7 Fuzzy membership values assigned to the geology when intra-Dalradian rankings were incorporated in to the geology theme. *Incorporated into final model.

Table 8 Fuzzy membership (FM) values assigned to each class within the geochemistry data theme for the Curraghinalt and Cavanacaw regional models.

Table 9 Fuzzy membership (FM) values assigned to each class within the geochemistry data theme for the Curraghinalt and Cavanacaw detailed models. 
Table 10 Fuzzy membership values assigned to each buffer around regional and second-order

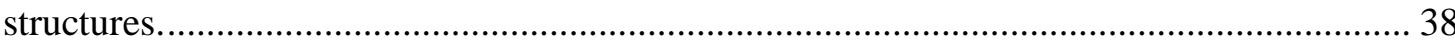

Table 11 Fuzzy membership values assigned to each buffer around known mineral occurrences. 38

Table 12 Fuzzy Logic operators as described by Bonham-Carter (1994) and Nykanen et al.

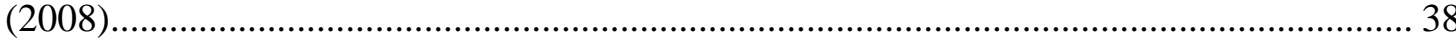

Table 13 Summary of criteria contributing to the prospectivity of the regional target areas ( $\mathrm{Cr}$ Curraghinalt specific; Cv - Cavanacaw specific) .............................................................. 52 


\section{Summary}

The Dalradian terrane of north-western Northern Ireland is an attractive target for orogenic vein mineralisation. The current high price of gold and the release in 2007 of high-quality regional geochemical and geophysical datatsets from the Tellus project have stimulated a marked revival of interest in this area. The results of the Tellus project, funded chiefly by the Department of Enterprise Trade and Investment (DETI), have provided major new insights into the geology and mineral potential of Northern Ireland.

Significant vein type orogenic gold mineralisation is known at several localities within this region. Previous studies of the most important deposits at Curraghinalt and Cavanacaw, and a review of similar mineralisation elsewhere in the world, allowed the definition of deposit models to underpin systematic prospectivity analysis of the Dalradian terrane in north-western Northern Ireland. Based on these models key exploration criteria were identified and, where appropriate data were available, these were extracted from various multivariate datasets (geology, geochemistry, geophysics and mineral occurrences). These criteria were then assigned significance weightings, zones and styles of influence based on the exploration model and the views of the team undertaking the analysis. A knowledge-based prospectivity analysis using Fuzzy Logic modelling was then applied to map the favourability for the occurrence of deposits of this type within the Dalradian terrane. ESRI's Arc Spatial Data Modeller version 3.1 (Arc SDM) software was employed for this purpose. The key exploration criteria are certain structural vectors and elevated values for gold and associated elements in Tellus stream-sediment geochemical data. On account of the apparent differences in the importance of structures of various orientations at Curraghinalt and Cavanacaw, and the contrast in the geochemicalmineralogical characteristics of the ores, two separate prospectivity models were applied in this study, one for Curraghinalt and the other for Cavanacaw. Mineral occurrence information from the GSNI MINLOCS database and the occurrence of gold grains observed during panning of stream sediments were also incorporated in the analysis.

Regional prospectivity analysis, covering an area of $3074 \mathrm{~km}^{2}$, using the two models identified 22 prospective targets for orogenic vein style gold mineralisation disposed in four groups. Many of the targets coincide with known orogenic gold occurrences while others occur in areas identified as prospective by previous workers. However in some areas the size of the targets has increased and elsewhere new targets have been identified beyond the main Lack - Curraghinalt zone. Of particular interest is a series of targets trending west-north-west, which passes through Curraghinalt and Golan Burn, which may relate to the major fault bounding the southern side of the Newtownstewart Basin. Another series of targets, disposed along a near-linear trend with a similar orientation, is identified to the north of the Omagh-Kesh Basin. A possible interpretation of these results is that both sets of targets are related to major structural features related to a westward extension of the Curraghinalt lateral ramp which is widely regarded as a critical control on the location of the Curraghinalt deposit.

The two prospectivity models were also applied to a sub-area of the terrane, the Newtownstewart map sheet, covering $560 \mathrm{~km}^{2}$. This analysis incorporated structural vectors derived from a more detailed evaluation of the Tellus geophysical datasets and from the revised 1:50 000 scale geological map for the Newtownstewart sheet published in 2007 which incorporated modified linework based in part on examination of the Tellus data. Comparison of the results of the regional and detailed analyses shows that, in the detailed analysis, the addition of structural data in areas devoid of such information in the regional analysis has led to an increase in the size of the targets identified. The detailed analysis has also identified extensive additional target areas, including zones of very high prospectivity, in the south-eastern quarter of the map sheet. 
This study has clearly demonstrated the value of knowledge-based prospectivity analysis in the Dalradian terrane of north-western Northern Ireland. The regional Tellus geochemical and geophysical datasets are critical to the application of this methodology. Further improvement of the technique is possible through implementation of a range of measures. The potential benefits from the use of a sample catchment approach to the geochemical drainage data should be investigated. A more detailed and comprehensive database of bedrock mineral occurrences would help validation of the prospectivity results and would also potentially allow the use of data-driven methods of analysis, removing the subjectivity inherent in knowledge-based methods. Addition of further high-resolution datasets would improve the utility of this approach for follow-up exploration. 


\section{Introduction}

Northern Ireland has a long history of mineral production and its diverse geology is prospective for a range of mineral deposit styles. Historical production largely focused on iron ore, coal, lead and salt, with in excess of 2000 abandoned mine workings (Mitchell, 2004). The occurrence of gold in Northern Ireland was originally documented in the mid-1600s with the discovery of alluvial grains in County Londonderry (Boate, 1652; Clifford et al. 1992). The first modern gold exploration in Northern Ireland was undertaken in the early 1980s in response to rising gold prices, interest in historical records of gold occurrences and a review of the mineral potential of the Sperrin Mountains area conducted by the Geological Survey of Northern Ireland (GSNI) (Arthurs, 1976). Exploration primarily focused on determining sources of alluvial gold in the Sperrin Mountains and successfully identified extensive shear zones with associated vein gold mineralisation in bedrock, indicative of a 'gold mineral province' (Clifford et al. 1992). The most significant discoveries were Curraghinalt (Clifford, 1986; Earls et al. 1989; Clifford et al. 1990; Clifford et al. 1992; Boland 1996; Earls et al. 1996a) and Cavanacaw (Lack), now the operating Omagh Mine (Cliff and Wolfenden 1992).

Caledonian basement rocks north of the Iapetus suture in the British Isles contain significant gold mineralisation extending from the Mayo-Curlew Basin of western Ireland (Cregganbaun and Croagh Patrick) (Thompson et al. 1992; Wilkinson and Johnston 1996) through the North Western Basement and Longford Down Massif (Curraghinalt, Cavanacaw and Clontibret) (Parnell et al. 2000; Cliff and Wolfenden 1992; Steed and Morris 1986) and into Scotland (Cononish, Calliacher-Urlar Burn, Glenhead, etc) (Curtis et al. 1993; Ixer et al. 1997) (Figure 1).

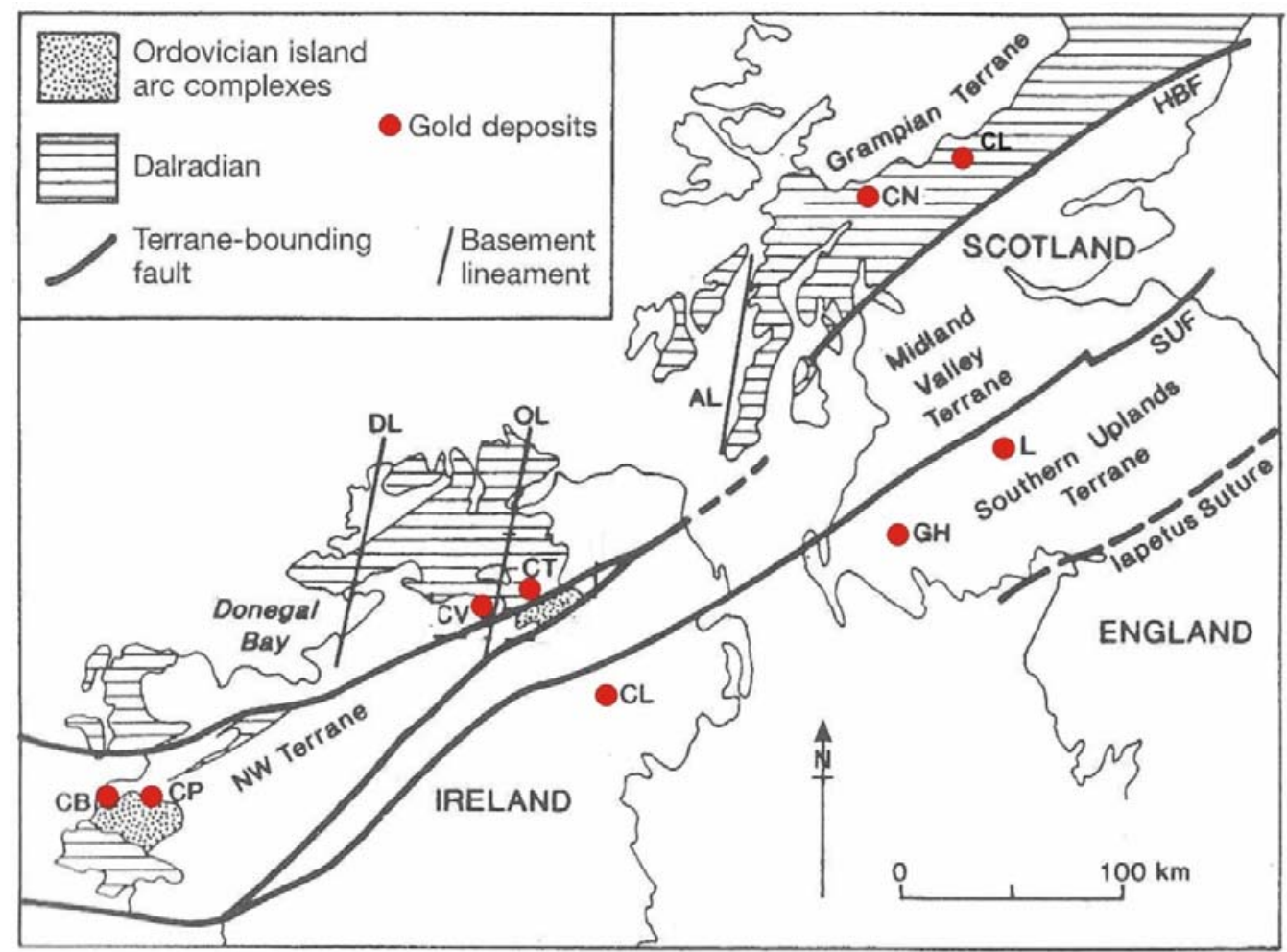

Figure 1 Major Caledonian structures and the location of significant gold deposits in Britain and Ireland. DL, Donegal Lineament; OL, Omagh Lineament; CB, Cregganbaun; CP, Croagh Patrick, CV, Cavanacaw, CT, Curraghinalt; CL, Clontibret, GH, Glenhead; L, Leadhills; CN, Cononish; CL, Calliacher-Urlar Burn (Adapted from Parnell et al. 2000). 
Rising commodity prices in recent years have spurred considerable interest in this highly prospective terrane. More than half of Northern Ireland is now under mineral prospecting licence or licence application, with a concentration of licences over the Sperrin Mountains (Figure 2). In addition a wealth of new geological, geochemical and geophysical data from the Tellus Project (2004-07) has provided new insights into the geology of Northern Ireland (www.tellus.detini.gov.uk). A low-level, high-resolution airborne geophysical survey of the whole of Northern Ireland, flown as part of the Tellus project, has improved delineation of faults, dykes and volcanic complexes, particularly in areas with thick glacial deposits and peat cover. In addition about 31000 soil, stream-sediment and stream-water samples were collected for analysis, providing baseline geochemical data for Northern Ireland (Earls, 2007). The Tellus Project was managed by the GSNI and funded by the Department of Enterprise Trade and Investment (DETI) with a contribution from the Rural Development Programme under the Northern Ireland Programme for Building Sustainable Prosperity.

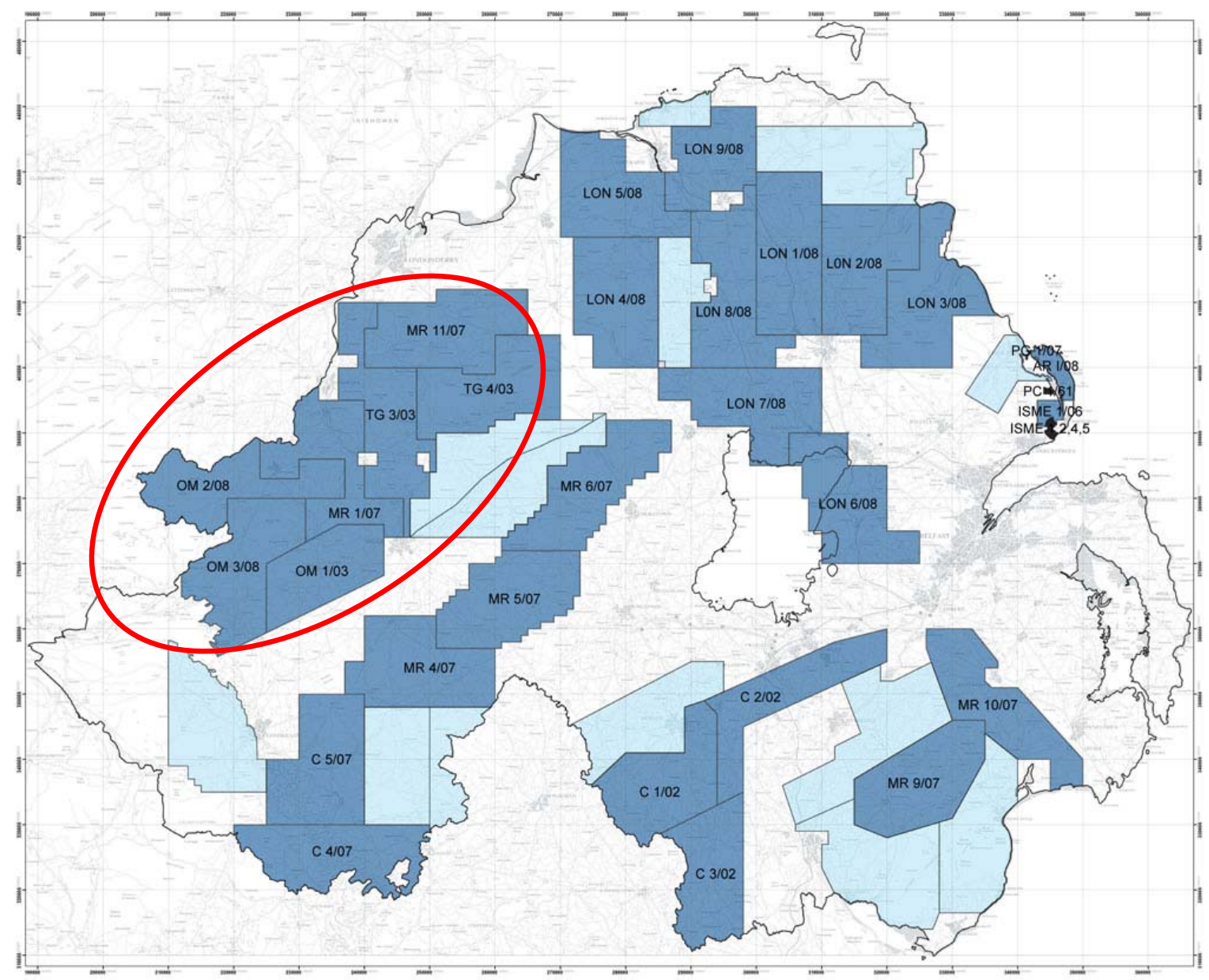

Figure 2 The distribution of exploration and mining licences in Northern Ireland, March 2008. A cluster of licences is present over the Dalradian rocks of the Sperrin Mountains (shown by the red outline).

The aim of this study was to assess the potential for orogenic gold deposits of vein type in northwest Northern Ireland using Geographic Information System (GIS)-based prospectivity analysis. Prospectivity analysis involves the analysis of multiple digital datasets that are integrated into a single prospectivity map that identifies favourable areas for new deposits based upon parameters of a particular mineral deposit model. This study utilised the Spatial Data Modeller extension 
(Arc-SDM, version 3.1), with ESRI's ArcGIS (www.esri.com) software (Kemp et al. 2001). The study integrates the new Tellus data, legacy datasets and updated geological mapping within a framework provided by the latest mineral deposit models for vein gold mineralisation in the Dalradian of Northern Ireland (Earls et al. 1996b; Parnell et al. 2000). The main data sets incorporated into the prospectivity analysis were:

- 1:250 000 scale geology of Northern Ireland (Figure 3);

- revised geological mapping at 1:50 000 scale of the Newtownstewart map sheet;

- geochemical data for stream-sediment samples from the Tellus project;

- geophysical features interpreted from the airborne geophysical data acquired by the Tellus project; and

- mineral occurrences from the Northern Ireland Mineral Localities Database (MINLOCS).

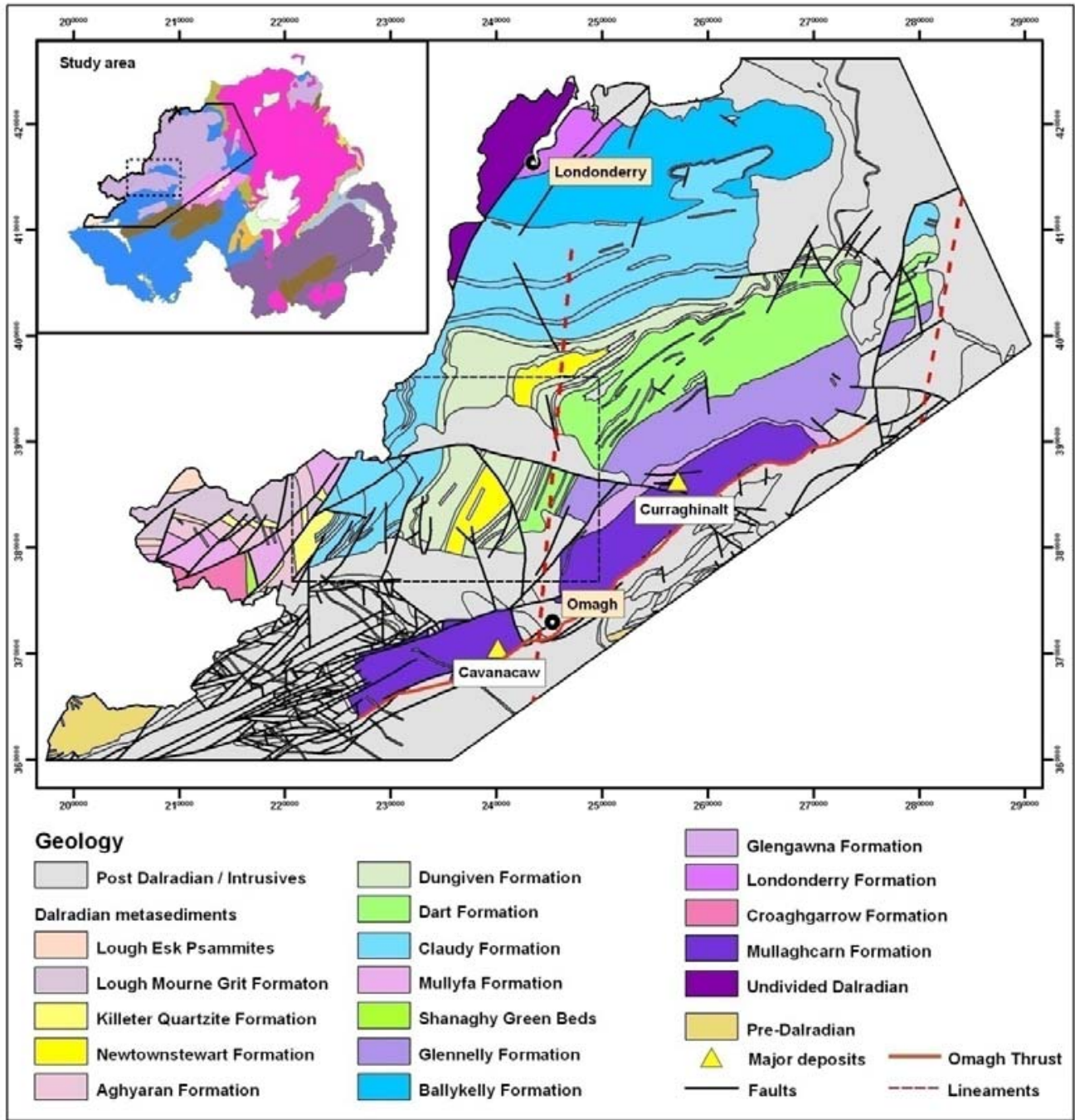

Figure 3 The location of the study area and the main gold deposits. The Newtownstewart map sheet area, selected for detailed analysis, is outlined by the dashed line.

The prospectivity analysis was carried out in two stages: first, a regional phase covering an area of $3074 \mathrm{~km}^{2}$ and, second, detailed analysis over a sub-area $\left(560 \mathrm{~km}^{2}\right)$ area based on the results of the regional analysis with the addition of certain extra data. The regional study area includes the 
main tract of Dalradian rocks in north-west Northern Ireland including parts of Counties Fermanagh, Tyrone and Londonderry, and was selected because of its prospective geology and known gold occurrences, including the gold deposits at Curraghinalt and Cavanacaw.

\section{Geological setting}

The prospectivity analysis focused on the Dalradian Supergroup in the Sperrin Mountains which form part of the Caledonian orogenic belt extending from Newfoundland, through western Ireland, Scotland and into Scandinavia.

The Dalradian Supergroup was formed as a consequence of the late Neoproterozoic break-up of the supercontinent of Rodinia and the opening of the Iapetus Ocean (Soper 1994). Deposition took place along the eastern side of Laurentia where extensive passive margin sedimentary sequences were formed in response to continental rifting and ocean widening, lasting until the early Ordovician (Strachan et al. 2002). The predominantly siliciclastic Dalradian sequences preserved in Scotland and Ireland record shallow to deep-water depositional environments with intercalated, subordinate lithologies recording periods of glaciation, carbonate deposition and basic volcanism.

In Ireland and Scotland, rocks of the Dalradian Supergroup are located within the Grampian Terrane bounded to the north and south by the Great Glen Fault and Highland Boundary Fault respectively (Bluck et al. 1992). The latter is well defined in Scotland, but less so in Northern Ireland where it is concealed by Devonian and younger cover sequences and the Omagh Thrust.

The regional structure and stratigraphy of the Dalradian Supergroup in the Sperrin Mountains has been the subject of longstanding debate. Based on GSNI mapping (GSNI 1997), the preferred structural interpretation is a broad anticline referred to as the Sperrin Nappe, which is considered analogous to the Tay Nappe in Scotland (Stephenson and Gould 1995). The Sperrin Nappe is south-east facing and composed mainly of Southern Highland Group formations disposed either side of an axis that runs within upper Argyll Group stratigraphy (GSNI 2004). An alternative model (Alsop and Hutton 1993) involves a greater proportion of Argyll Group stratigraphy forming the main Sperrin ridge, with a main axis sitting further south than proposed by GSNI. The structure and stratigraphy of the Sperrin Mountains revealed by recent mapping of the Dungiven (GSNI 2007), Newtownstewart (GSNI 2008) and Strabane (in prep) 1:50 000 scale sheets is more consistent with the interpretation of Alsop and Hutton, but appears to be far more structurally complicated than previously thought. From north-west to south-east, a succession of folds and thrust surfaces is identified that repeats a relatively thin portion of upper Argyll Group and lower Southern Highland Group stratigraphy.

\subsection{GEOLOGY OF THE NEWTOWNSTEWART SHEET}

The Newtownstewart sheet is situated in the western Sperrin Mountains. Its bedrock geology is composed mainly of Dalradian, upper Argyll Group siliciclastic lithologies with minor carbonates and basic volcaniclastic tuffs, pillow lavas and metabasite sills. Lithological divisions, the main structural fabric (F2) and thrust surfaces are parallel to one another and mainly orientated north-east to south-west. Metamorphic grade varies between upper greenschist and lower amphibolite, and increases from north-west to south-east. South-east of the base of the Glengawna Formation the sequence is inverted (younging to the south-east) and is cut by numerous thrust surfaces that are associated with graphitic semipelite horizons. The sequence youngs north-west of the Glengawna and has been divided into the Glenelly, Dart and Dungiven Formations. The latter includes the Bonds Glen Limestone Member which is correlated with meta-limestone-bearing formations in Ireland and Scotland. Lithological repetition reflects a 
number of isoclinal folds, but also occurs because of the thrust surfaces. It is envisaged that the Glengawna and its associated thrust surfaces reflect a significant dislocation within the regional structure.

Late Caledonian minor intrusions, present across the entire Newtownstewart sheet, are generally parallel to the strike and have been emplaced along thrust surfaces. One intrusion has been dated at c. $430 \mathrm{Ma}$ (Cooper et al. in press) suggesting that the thrusts are older and most likely to be of Grampian age. Regionally, the intrusions occur west of the deep-seated Omagh Lineament which runs down the eastern side of the sheet.

The Dalradian is unconformably overlain by Lower Carboniferous siliciclastic sequences, of which the Courceyan Spincha Burn Conglomerate Formation and Barony Glen Formation are present within the east-west-trending Newtownstewart Basin. The southern boundary of this basin is a normal fault the eastern extension of which on the Draperstown sheet (GSNI 1995) is associated with the Curraghinalt gold deposit. The western extension of this fault cuts Dalradian basement on the Newtownstewart sheet. The Newtownstewart sheet is cross-cut by a network of north-north-east- and north-north-west-orientated Variscan faults including the regionally significant Pettigoe Fault. However, the disposition of Dalradian and Carboniferous rocks across some of these faults indicates that both reverse and normal movements have occurred at different times. The displacement of Palaeogene dolerite dykes across the Pettigoe Fault records sinistral movement that regionally, through the interpretation of Tellus magnetic data, can be shown to be synmagmatic (Cooper et al. in prep).

\section{An introduction to prospectivity analysis}

Geographical Information Systems (GIS) are essential tools for the management and integration of the large amounts of spatial data of many types used in mineral exploration. GIS allows effective visualisation and querying of the data or themes to determine which parameters are critical or incidental to the mineralising process. Mineral prospectivity modelling is an advanced form of GIS analysis used to answer complex spatial questions and to identify patterns and associations that may otherwise not be apparent in large datasets. A mineral deposit models describes the essential attributes of a mineral deposit class, based on the synthesis of large amounts of data. Such models provide an essentially qualitative basis for exploration and resource assessment and can aid the identification of key exploration criteria for a particular type of deposit, thus forming the basis for analysis of the mineral potential of a region.

Data integration techniques in GIS can be categorised into data-driven models (Weights of Evidence modelling and logistic regression) and knowledge-driven models (Fuzzy Logic and neural networks) (Bonham-Carter, 1994). Data-driven approaches are probability-based techniques for mapping mineral potential using the spatial distribution of known mineral occurrences. The approach aims to relate or 'train' all specified datasets to known occurrences of the particular mineral deposit type within the region and, by association, highlight those data relationships which closely mimic the patterns at the known occurrences. Weights are estimated from the measured association between known occurrences and the values on the maps to be used as predictors (Wang et al. 2002). 


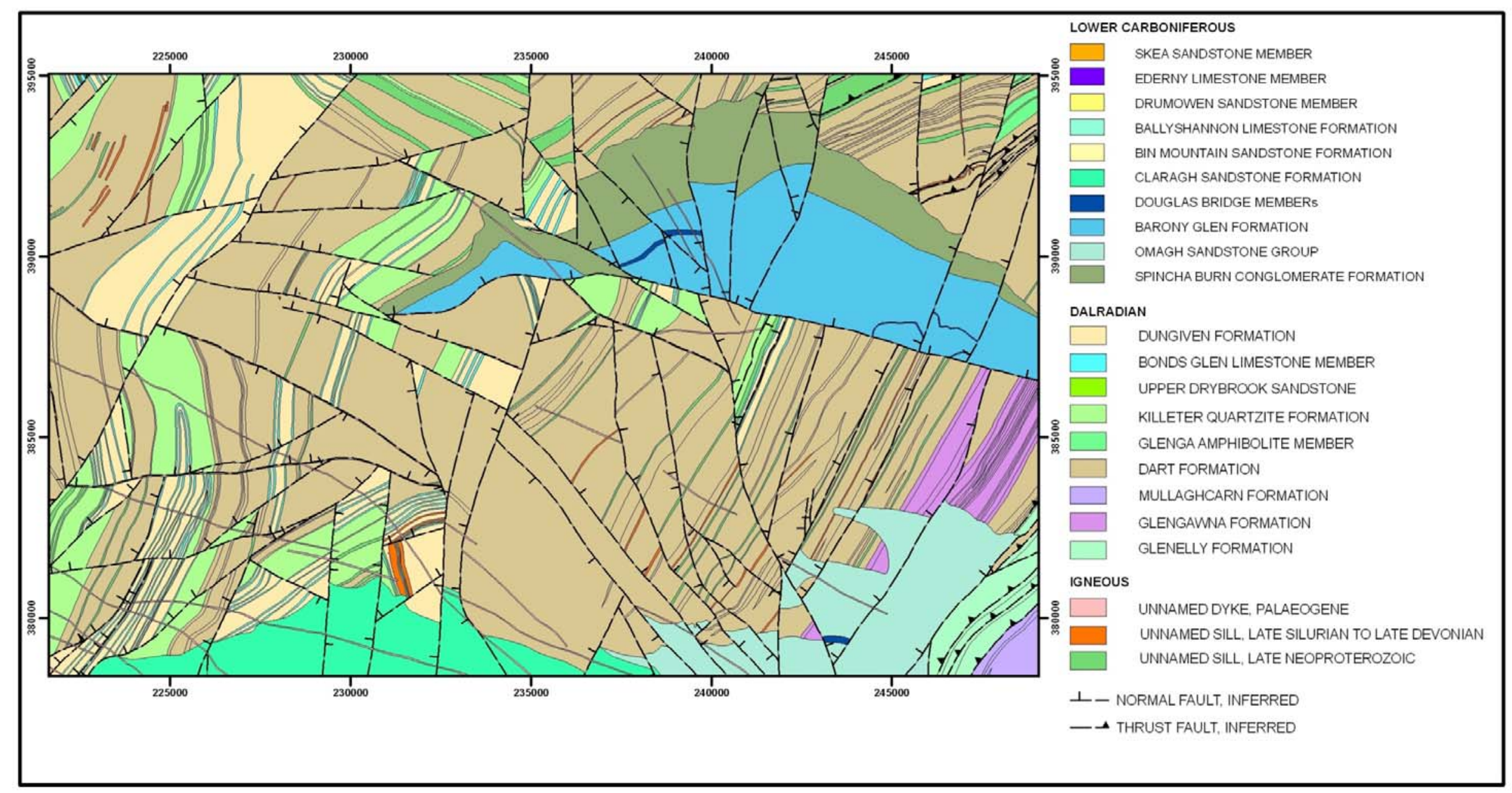

Figure 4 Geology of the Newtownstewart sheet (GSNI, 2007). 
Knowledge-driven analyses establish the relationship between the spatial exploration datasets and the exploration model and are often employed in regions with few or no known mineral occurrences with which to 'train' the exploration datasets. Knowledge-driven techniques such as Fuzzy Logic are subjective in that the 'explorationist' determines the relative significance of the exploration datasets and assigns a significance weighting based on the exploration model. Knowledge-based prospectivity mapping is achieved by extracting the spatial relationships from exploration datasets on the basis of the exploration model, quantifying these spatial relationships and integrating them using mathematical operators chosen by the user. The output of Fuzzy Logic modeling is a map of mineral potential. Fuzzy Logic prospectivity analysis has been applied to exploration for orogenic gold deposits in many countries including in the Yilgarn Block, Western Australia (Groves et al. 2000) and the northern Fennoscandian Shield, Finland (Nykanen and Ojala, 2007). In the UK prospectivity analysis has been used to determine favorable areas for mesothermal lode gold in the Scottish Dalradian (Gunn et al. 1997) and turbidite-hosted gold, within the Lower Paleozoic Welsh Basin (Cooper et al. 1999).

Prospectivity analysis is based on a general series of procedures:

i. A review of the mineral deposit model.

ii. Determination of the key exploration indicators from the mineral deposit model.

iii. Review of dataset availability for the area under investigation.

iv. Data processing, interpretation and analysis to extract the key indicators.

v. Assignment of weightings, zones and styles of influence to key indicators (expert parameterisation).

vi. Calculation of prospectivity using knowledge-driven or data-driven methods.

For a detailed explanation of the mathematics underlying Weights of Evidence and Fuzzy Logic the reader is referred to Bonham-Carter (1994).

As a result of the limited number of gold deposits and occurrences in the present study area, and the consequent lack of a 'training' dataset, knowledge-driven prospectivity analysis using Fuzzy Logic was employed in this study. It is important to note that the dataset containing the location of significant deposits and gold occurrences in the study area was not included as an evidence layer in the modelling. This allowed these points to be used for subsequent validation and comparison with the results of the model.

\section{Mineral deposit models and key exploration criteria}

\subsection{OROGENIC GOLD DEPOSITS}

Gold mineralisation is widely developed throughout the Caledonian orogenic belt, from Scandinavia in the north to the south-eastern USA in the south. Goldfarb et al. (2001) identified gold deposits associated with the Caledonian Orogeny in the British Isles as examples of Palaeozoic orogenic gold mineralisation. Although there are differences in detailed fluid characteristics it is generally accepted that orogenic gold mineralisation is associated with low salinity (typically in the range of 3-7 wt. \% eq. $\mathrm{NaCl}$ ), mixed aqueous-carbonic fluids, transporting gold as reduced sulphur complexes, most compatible with a metamorphic devolatilisation or deep magmatic source. Mineralising conditions generally fall in the range of $1.0-2.5$ kbars at $300-350^{\circ} \mathrm{C}$ (Ridley and Diamond 2000). Orogenic gold deposits are typified by quartz-carbonate-dominant vein systems associated with deformed metamorphic terranes of all ages. Mineralisation displays strong structural controls at a variety of scales. Deposits are most commonly located on second- or third-order structures in the vicinity of large-scale 
compressional or transpressional structures formed at convergent margins (Groves et al. 2003) (Table 1).

\begin{tabular}{|c|c|}
\hline Criteria & Identified in project area \\
\hline Collisional tectonic regime $^{1}$ & Yes \\
\hline Major accretionary boundary structures ${ }^{1}$ & Yes \\
\hline 'First-order' transcrustal structures ${ }^{1}$ & Yes \\
\hline High angle 'second-order faults' related to major structures ${ }^{2,3}$ & Yes \\
\hline Rocks of greenschist metamorphic grade $^{1}$ & Yes \\
\hline Mineralisation is post-peak metamorphism (i.e. late syncollisional) $^{2}$ & Yes \\
\hline Late syncollisional, intermediate to felsic magmatism ${ }^{2,4}$ & Unknown \\
\hline $\begin{array}{l}\text { Tabular veins in more competent lithologies with veinlets and stringers } \\
\text { forming stockworks in less competent units }{ }^{2}\end{array}$ & Yes \\
\hline $\begin{array}{l}\text { Ore mineralogy - gold, pyrite, arsenopyrite, native gold, } \mathrm{Cu}, \mathrm{Pb}, \mathrm{Zn} \text { and } \\
\text { Sb sulphides }{ }^{1}\end{array}$ & Yes \\
\hline Gangue mineralogy dominated by quartz \pm carbonate, feldspar, mica ${ }^{2}$ & Yes \\
\hline Wall-rock alteration $^{1}$ & Variable \\
\hline $\begin{array}{l}\text { Elevated values for } \mathrm{Au}, \mathrm{Ag}, \mathrm{As}, \mathrm{Sb}, \mathrm{K}, \mathrm{Li}, \mathrm{Bi}, \mathrm{W}, \mathrm{Te}, \mathrm{Cu}, \mathrm{Pb}, \mathrm{Zn}, \mathrm{Cd} \text { in } \\
\text { rock, soil, stream-sediment }^{2}\end{array}$ & $\begin{array}{l}\text { Selected elements (see text } \\
\text { for discussion) }\end{array}$ \\
\hline Mineralisation associated with metamorphic fluids ${ }^{1,4}$ & Yes \\
\hline $\mathrm{C}-\mathrm{O}-\mathrm{H} \pm \mathrm{N}$, near-neutral to low $\mathrm{pH}$, low salinity fluids ${ }^{1,4}$ & Yes \\
\hline
\end{tabular}

Table 1 Key exploration criteria for Phanerozoic orogenic vein gold mineralisation and their occurrence in the study area (criteria compiled from: ${ }^{1}$ Birerlein and Crowe (2000); ${ }^{2}$ Ash et al. (1996); ${ }^{3}$ Nesbitt (1993); ${ }^{4}$ Earls et al. (1996b)).

\subsection{OROGENIC GOLD DEPOSITS IN NORTHERN IRELAND}

A number of publications have contributed to the understanding of gold mineralisation in the Sperrin Mountains of Northern Ireland, including the principal controls on the location of mineralisation e.g. Wilkinson et al. (1999); Parnell et al. (2000); Earls et al. (1996b). The majority of research has focused on the deposits at Curraghinalt and Cavanacaw from which the prospectivity models used in this study have been derived.

\subsubsection{Curraghinalt}

A shallow soil geochemical anomaly led to the discovery of Curraghinalt in 1983 with subsequent deep overburden sampling, trenching, drilling and a limited amount of underground development. The Curraghinalt deposit consists of a series of west-north-west trending, northeast dipping gold-bearing quartz veins, related to east-west trending vertical and northerly dipping shear zones. The auriferous veins are cut by low angle, north-dipping thrust faults and north-east-trending normal faults (Parnell et al. 2000; Clifford et al. 1992; Earls et al. 1996b). Structural evidence suggests Curraghinalt overlies a lateral ramp structure (discussed below). Earls et al. (1996b) propose a model whereby space was created by predominantly east-southeast directed thrusting over the footwall ramp, resulting in the formation of east-west orientated accommodation structures. Minor changes in thrusting direction relative to the strike of the ramp resulted in both contractional and extensional deformation of the hanging wall Dalradian rocks creating space in the system (Earls et al. 1996b). The veins bifurcate, pinch and swell along strike in a host sequence of pelites, semipelites and psammites, varying in width from a few millimetres up to 3 metres (Clifford et al. 1992; Mitchell, 2004). Curraghinalt is located within 
rocks of the Mullaghcarn Formation. The latest published resource for the Curraghinalt deposit is an indicated resource of 250000 ounces of gold contained in 570000 tonnes of material with an average grade of 13.95 grams of gold per tonne and an inferred resource of 350000 ounces of gold contained in 640000 tonnes of material with an average grade of 17.15 grams of gold per tonne, based on a cut-off of 6 grams of gold per tonne and a minimum vein width of 1 metre (Mincon, 2007).

\subsubsection{Cavanacaw}

Cavanacaw lies in the eastern part of the Lack Inlier which appears to contain parts of both the Mullaghcarn and Glengawana Formations (Earls et al. 1996b). Stream-sediment geochemistry over the Lack Inlier returned anomalous results for gold, lead and arsenic and subsequent prospecting located outcropping gold mineralisation in 1985. The largest mineralised structure at Cavanacaw, the Kearney vein, strikes north-south, whilst an additional set of veins strikes southeast. An east-north-east-striking fracture system known as the 'Lack Shear' displaces both veins sets (Cliff and Wolfenden, 1992). A proven and probable reserve has been published for the Omagh Mine of 367310 tonnes grading 7.52 grams of gold per tonne over a width of 4.43 metres, based on a cut-off grade of 1 gram of gold per tonne and a cut-off width of 0.5 metre. In addition using the above cut-offs, an indicated resource of 1183680 tonnes at a grade of 7.02 grams per tonne over a width of 4.43 metres has been calculated (ACA Howe, 2003).

\subsubsection{Other mineralised localities}

In addition to Curraghinalt and Cavanacaw other notable mineralised localities in the district include (Figure 5):

- Golan Burn, approximately $4 \mathrm{~km}$ west-north-west of Curraghinalt, which may represent the north-west strike extension of the Curraghinalt mineralisation (Mitchell, 2004);

- Rylagh and Erganagh Burns, north-east of Cavanacaw, consisting of north-south-trending, shear zone-associated auriferous quartz veins;

- Creeven Burn, to the south of Cavanacaw, where mineralisation is associated with the Lack Shear and graphitic pelites; and

- Cornavarrow, west of Creevan Burn, also within the Lack Shear, where auriferous quartz veins are hosted in low-angle faults in graphitic pelites and psammites (Earls et al. 1996b). 


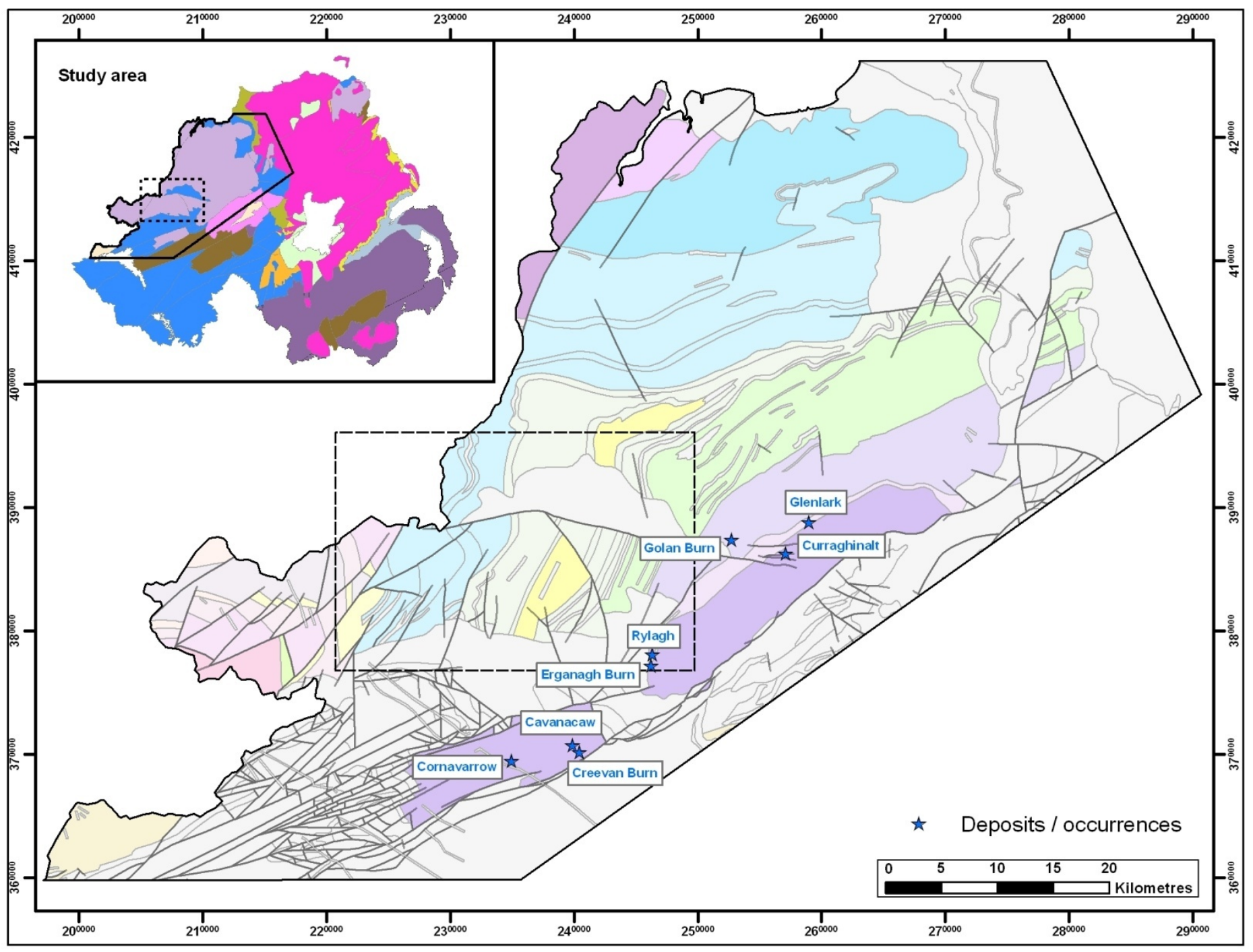

Figure 5 The location of the Curraghinalt and Cavanacaw deposits and other occurrences of auriferous vein style mineralisation. 


\subsubsection{Controls on mineralisation}

Structure appears to be the most significant factor controlling the distribution of auriferous gold veins in the Sperrin Mountains. Earls et al. (1996b) suggest that the interplay of three main geological structures influence the location of mineralisation (Figure 3, Table 2):

1) An inferred deep basement structure, designated the Omagh Lineament, extends through the study area. Similar features have been identified in the Dalradian of north-west Donegal and south-west Scotland (Hutton and Alsop 1996). This north-north-east-trending, pre-Dalradian structure, possibly as old as $1800 \mathrm{Ma}$, is likely to have controlled Dalradian sedimentation patterns and is associated with an increase in mantle-derived, tholeiitic magmatism and is responsible for a major change in bedding orientation and the dominant foliation in Dalradian rocks to the east of the Lack Inlier (Earls et al. 1996b; Mitchell, 2004). Earls et al. (1996b) concluded that the Omagh Lineament has a significant control on the location and orientation of mineralised veins, based on the distribution of gold and arsenic anomalies and the north-north-east or north-south orientation of mineralised veins in the vicinity of the Lack Inlier.

2) The north-east-trending Omagh Thrust which demarcates the southern boundary of the Lack-Curraghinalt zone. During the early to mid Ordovician (c.470-480 Ma) the Dalradian was thrust over the volcanics of the Tyrone Igneous Complex along this zone of south-east directed thrusting. Subsequent reactivation of this structure during the Variscan (c. 300 Ma) resulted in thrusting of the Dalradian over Carboniferous and Devonian rocks in addition to the Tyrone Igneous Complex (Earls et al. 1996b).

3) The west-north-west-trending, north-dipping Curraghinalt Lateral Ramp. This structure developed in the footwall of the Omagh Thrust, in the Tyrone Igneous Complex resulting in a regime of north-west directed extension and the formation of east-west orientated accommodation structures (Earls et al. 1996b).

The gold mineralisation displays an important relationship to the overturned Sperrin Fold (Figure 3) with the majority of occurrences sited on the inverted, moderately north-west-dipping limb (Earls et al. 1996b). The principal exploration targets for gold mineralisation in the Sperrin Mountains are Dalradian metasedimentary rocks. However, Lower Carboniferous and other postDalradian lithologies are also considered prospective for gold mineralisation, following the suggestion by Wilkinson et al. (1999) that pre-existing Caledonian gold mineralisation may have been remobilised by later low-temperature brines. In general mineralised veins are preferentially developed in relatively brittle psammitic units in contrast to the more ductile pelites (Clifford et al. 1992; Earls et al. 1996b). Earls et al. (1996b) indicate an apparent association between gold mineralisation and graphitic pelite horizons of the Glengawna Formation.

Quartz is the dominant mineral in veins in these deposits but several carbonates phases, including calcite, dolomite and siderite, also occur. Four phases of quartz deposition have been recognised at Curraghinalt.. A primary barren phase of quartz deposition (Q1) is thought to postdate the main Caledonian metamorphic event (470-480 Ma) (Earls et al. 1996b). A second phase (Q2) of auriferous quartz deposition is associated with reactivation and brecciation of the earlier veins, between 470 and 400 Ma. During subsequent reactivation of the deposit further quartz (Q3) precipitation occurred from a formation water (Parnell et al. 2000). The final phase of quartz deposition (Q4) is associated with probable Variscan reactivation of the veins and a lowtemperature brine. This low-temperature basinal brine is suggested to have caused remobilisation of second phase gold (Earls et al. 1996b). Common sulphides associated with mineralised veins throughout the Sperrins are pyrite, arsenopyrite, chalcopyrite, galena and sphalerite (Parnell et al. 2000). 


\begin{tabular}{|c|c|}
\hline Criteria & Rationale \\
\hline Known mineral occurrences & $\begin{array}{l}\text { Metalliferous mineralisation is the exploration target } \\
\text { and well documented in the district }{ }^{1}\end{array}$ \\
\hline Quartz-carbonate veins & $\begin{array}{l}\text { Gold mineralisation is intimately associated with } \\
\text { veining }\end{array}$ \\
\hline $\begin{array}{l}\text { Ore mineralogy of pyrite, arsenopyrite, } \\
\text { chalcopyrite, galena and sphalerite }\end{array}$ & Minerals associated with auriferous veins \\
\hline $\begin{array}{l}\text { Geochemical anomalies: Au-Ag-Bi-As-Cu- } \\
\mathrm{Pb}-\mathrm{Zn}\end{array}$ & $\begin{array}{l}\text { Indicator of proximity to mineralisation. Pathfinders } \\
\text { for gold based on geochemical characteristics of } \\
\text { orogenic gold deposits, ore mineralogy and } \\
\text { documented associations }{ }^{1}\end{array}$ \\
\hline $\begin{array}{l}\text { Wall-rock alteration - potassic, argillic, } \\
\text { carbonate, propylitic }\end{array}$ & $\begin{array}{l}\text { Alteration is common in the veins and may be used } \\
\text { as a vector towards mineralisation but intensity and } \\
\text { extent are variable e.g. at Curraghinalt it is minimal }\end{array}$ \\
\hline Crustal-scale faults & $\begin{array}{l}\text { Control second-order faults; crustal-scale faulting is } \\
\text { directly linked to space creation in the area of } \\
\text { Curraghinalt }^{1}\end{array}$ \\
\hline Second-order faults & Structural control at a local level \\
\hline Major basement structures & $\begin{array}{l}\text { Potentially important zones of fluid transport and } \\
\text { mineralisation, and an important structural control, } \\
\text { allowing the Dalradian to accommodate N-S-trending } \\
\text { veins }^{1}\end{array}$ \\
\hline Structural orientation & $\begin{array}{l}\text { Mineralisation is controlled by structures of } \\
\text { particular orientation }\end{array}$ \\
\hline Pre-Dalradian rocks & $\begin{array}{l}\text { Potentially mineralised, but of very limited extent in } \\
\text { the study area }\end{array}$ \\
\hline Dalradian metasedimentary rocks & $\begin{array}{l}\text { All significant vein gold occurrences are associated } \\
\text { with Dalradian rocks }{ }^{1} \text { (Table } 4 \text { provides details of the } \\
\text { exploration significance of individual formations) }\end{array}$ \\
\hline Post-Dalradian rocks & Potential hosts for remobilised Caledonian gold $^{1}$ \\
\hline Psammitic units & $\begin{array}{l}\text { More favourable rheological properties for vein } \\
\text { development than ductile pelite horizons }{ }^{1}\end{array}$ \\
\hline Graphitic pelite horizons & $\begin{array}{l}\text { Observed association between mineralisation and } \\
\text { graphitic pelite horizons and a suggestion that less } \\
\text { competent horizons may have increased local } \\
\text { permeability }^{1}\end{array}$ \\
\hline
\end{tabular}

Table 2 Key exploration criteria for vein gold mineralisation in Northern Ireland $\left({ }^{1}\right.$ Earls et al. (1996b)).

Although the regional geological setting is the same for both the Curraghinalt and Cavanacaw deposits and they have many common features (Table 2), significant differences are observed at the deposit scale, including the principal structural controls, mineralogy and geochemical signatures. As a result two separate prospectivity models were developed, one for Curraghinalt and the second Cavanacaw. Table 3 shows the relative weightings allocated to regional structures, other structural vectors and geochemical criteria in the two models.

\subsubsection{STRUCTURE}

The north-east-trending Omagh Thrust and the inferred north-south-trending basement lineaments are considered prospective in both models due their regional influence as a zone of fluid flow and a structural control. Both Curraghinalt and Cavanacaw lie in close proximity to these structures. The Omagh Thrust is directly linked to space creation in the vicinity of Curraghinalt and is accordingly given greater weighting in the Curraghinalt model than in the 
Cavanacaw model. Greater significance is given to the basement lineaments in the Cavanacaw model as the Omagh Lineament is thought to have allowed the Dalradian to accommodate northsouth-trending veins and extensional shear zones such as those which occur at Cavanacaw and Rylagh (Earls et al. 1996b).

North-east-trending structures are considered prospective in both models, reflecting the importance and orientation of the Omagh Thrust and parallel structures that may exist. This trend also corresponds to the orientation of the normal faults cutting the veins at Curraghinalt. This orientation has greater significance in the Curraghinalt model due to the close association between the north-east-trending Omagh Thrust and space creation in the deposit.

A north-south orientation corresponds to the trend of the inferred basement lineaments and orientation of mineralised veins at Cavanacaw. Accordingly structures with this orientation are given greater weighting in the Cavanacaw model.

East- to east-south-east-trending structures are considered highly prospective in the Curraghinalt model on the basis of the orientation of the Curraghinalt vein swarm (east-south-east) which appears related to east-west-trending shear zones (Earls et al. 1996b). The Curraghinalt Lateral Ramp, which appears critical to development of the mineralisation, also has the same trend. This structure is not represented as a separate entity in the model as its extent is not clearly defined. In the Cavanacaw model south-south-east- and east-north-east-trending structures are considered prospective, relating to the orientation of a subsidiary vein set and the Lack Shear at Cavanacaw, respectively (Cliff and Wolfenden, 1992).

\begin{tabular}{|l|l|l|}
\hline \multirow{2}{*}{ Criteria } & \multicolumn{2}{c|}{ Significance } \\
\cline { 2 - 4 } & Curraghinalt & Cavanacaw \\
\hline Proximity to Omagh Thrust & $\mathrm{h}$ & $\mathrm{m}$ \\
\hline Proximity to basement lineaments & $\mathrm{l}$ & $\mathrm{h}$ \\
\hline Proximity to NE-SW structures & $\mathrm{h}$ & $\mathrm{l}$ \\
\hline Proximity to N-S structures & $\mathrm{l}$ & $\mathrm{h}$ \\
\hline Proximity to E-W to ESE-WNW structures & $\mathrm{h}$ & $\mathrm{na}$ \\
\hline Proximity to SSE-NNW structures & $\mathrm{na}$ & $\mathrm{m}$ \\
\hline Proximity to ENE-WSW structures & $\mathrm{na}$ & $\mathrm{m}$ \\
\hline & & \\
\hline Au in stream-sediment samples & $\mathrm{h}$ & $\mathrm{h}$ \\
\hline Ag in stream-sediment samples & $\mathrm{m}$ & $\mathrm{m}$ \\
\hline As in stream-sediment samples & $\mathrm{m}$ & $\mathrm{h}$ \\
\hline Cu in stream-sediment samples & $\mathrm{l}$ & $\mathrm{m}$ \\
\hline Pb in stream-sediment samples & $\mathrm{l}$ & $\mathrm{h}$ \\
\hline Zn in stream-sediment samples & $\mathrm{l}$ & $\mathrm{l}$ \\
\hline Significace & & \\
\hline
\end{tabular}

Significance: h, high; m, medium; l, low; na, not applicable

Table 3 The significance assigned to regional structures, other structural vectors and geochemical criteria in the two prospectivity models used in this study, referred to as the Curraghinalt and Cavanacaw models.

\subsubsection{GEOCHEMISTRY}

Geochemical data for mineralised samples indicates significant mineralogical and geochemical differences between the Curraghinalt and Cavanacaw mineralisation. Earls et al. (1996b) 
undertook a comprehensive review of the geochemistry of a wide range of host rock and vein samples from Curraghinalt, Cavanacaw, Golan Burn and other vein occurrences throughout the Sperrin Mountains. This study aimed to determine precious- and base-metal distributions in the mineralisation and to clarify the geochemical-mineralogical associations of these metals in the veins. The following conclusions were drawn:

- $\quad$ Ag is associated with both Au (as electrum) and galena in the veins.

- Bulk Au/Ag ratios vary considerably between Curraghinalt (median values of $13.4 \mathrm{ppm}$ Au and 6.7 ppm Ag) and Cavanacaw (16.7 ppm Au and 44 ppm Ag).

- Cavanacaw veins are considerably richer in Ag than Curraghinalt veins.

- In comparison to Cavanacaw, Curraghinalt veins have greater $\mathrm{Bi}$ and $\mathrm{Cu}$ concentrations and lower $\mathrm{Pb}$, As and Sb concentrations.

- Au contents are correlated with those of Bi and As at Curraghinalt and with Ag, As, Ce, $\mathrm{Cu}$ and $\mathrm{Pb}$ at Cavanacaw.

- A strong positive association is present between Au and Ag in the Curraghinalt samples although regional samples and Cavanacaw mineralisation display a more variable relationship between $\mathrm{Au}$ and $\mathrm{Ag}$.

- A weak positive correlation exists between $\mathrm{Au}$ and $\mathrm{As}$ in the Curraghinalt mineralisation.

- $\mathrm{Cu}$ is not positively correlated with $\mathrm{Au}$ at Curraghinalt, unlike at Cavanacaw where $\mathrm{Cu}$, in the form of chalcopyrite, is clearly associated with Au-Ag.

- The highest $\mathrm{Cu}$ value was derived from a Curraghinalt sample, with several other samples from Curraghinalt and Cavanacaw displaying elevated $\mathrm{Cu}$.

- Cavanacaw samples returned $\mathrm{Pb}$ values of up to $1.66 \%$, whilst the Curraghinalt mineralisation is distinctly poor in $\mathrm{Pb}$.

- Sphalerite has not been identified in the Curraghinalt mineralisation. It is a minor phase at Cavanacaw (Parnell et al. 2000) but is a significant component of some of the regional veins (Earls et al. 1996b). Curraghinalt vein samples returned between 100-2000 ppm Zn.

- Most elevated Bi values were obtained from Curraghinalt, where a moderate to strong positive correlation is apparent between $\mathrm{Bi}$ and $\mathrm{Au}-\mathrm{Ag}$.

- The highest Sb values were obtained from the Cavanacaw mineralisation. Sb and $\mathrm{Au}$ display a weak positive relationship.

- Barite occurs as veinlets cross-cutting early quartz veins. At Curraghinalt barite is observed with later stage quartz, intimately associated with sulphides (Earls et al. 1996b).

Earls et al. (1996b) also undertook a review of stream-sediment data from the Sperrin Mountains and made a comparison with the lithogeochemical data discussed above. The following key points emerged from this review:

- As anomalies are associated with the Cavanacaw and values are regionally elevated (mean 38 ppm), reaching highly anomalous levels (>218 ppm).

- $\mathrm{Cu}$ values display stratigraphical control, with above average concentrations over the Dart and Glenelly Formations.

- Highly anomalous $\mathrm{Pb}$ values occur south-west and north-east of Omagh in the vicinity of the Omagh Thrust and Cavanacaw. Pb anomalies reportedly disappear rapidly along strike to the north-east and stream sediment samples from the Curraghinalt area are not anomalous in $\mathrm{Pb}$.

- Zn anomalies are largely stratigraphically controlled relating to the Dart and Dungiven Formations.

- Ba also displays strong stratigraphical differentiation with generally elevated values from the Glenelly and Owenkillew catchments. Ba anomalies north-east of Rylagh are associated with barite mineralisation (Earls et al. 1996b; Flight et al., 1995). 


\section{Data and data processing}

Regional prospectivity analysis using two models, the Curraghinalt and Cavanacaw models, was conducted over an area of $3074 \mathrm{~km}^{2}$ (Figure 3). Subsequently the two models were applied to a smaller sub-area $\left(560 \mathrm{~km}^{2}\right)$ covering the Newtonstewart 1:50 000 scale map sheet. The following data classes were used in the analysis.

\subsection{GEOLOGY}

The regional prospectivity analysis utilised the 1:250 000 scale geological linework published by the GSNI (GSNI, 1997). This is the only complete 'seamless' geology currently available for Northern Ireland. The study area covers parts of ten GSNI 1:50 000 scale geological map sheets, which do not have seamless boundaries.

Analysis of the Tellus geophysical and geochemical datasets has significantly enhanced the geological understanding of parts of Northern Ireland. The 1:50 000 scale geological linework for the Newtownstewart area (GSNI, 2007) is one of the first map sheets for Northern Ireland to be revised on the basis of this data.

For the initial prospectivity analysis the geology (Figure 3) was generalised into pre-Dalradian, Dalradian and post-Dalradian groupings with three different weightings (fuzzy membership values) applied (Figure 6). At this stage it was decided not to differentiate the Dalradian Supergroup based upon favourability for mineralisation because of limited published evidence for a strong stratigraphical control. It was subsequently decided to variably rank the Dalradian formations based upon their perceived prospectivity for gold mineralisation (principally based on favourable rheological properties). Accordingly a ranking scheme was devised by Garth Earls (pers. comm.) (Table 4). The ranking supplied did not provide a full breakdown of all Dalradian formations found in the regional study area. As a result it was necessary to determine an equivalent stratigraphy across the study area based upon the divisions shown in Table 4.

\begin{tabular}{|l|l|}
\hline Formation name & Rank \\
\hline Glengawna Formation & 10 \\
\hline Mullaghcarn Formation & 8 \\
\hline Dungiven Formation (Carbonates) & 6 \\
\hline Dungiven Formation (Non-carbonate) & 5 \\
\hline Glenelly Formation & 5 \\
\hline Dart Formation & 5 \\
\hline Newtownstewart Formation & 5 \\
\hline Londonderry Formation & 3 \\
\hline Ballykelly Formation & 5 \\
\hline
\end{tabular}

Table 4 Relative ranking of Dalradian Formations in the Sperrins based upon favourability for hosting gold mineralisation (10 = highest favourability) (Garth Earls pers. comm.).

The only exploration criterion identified which was not incorporated in the modelling was alteration. This was omitted because no appropriate alteration dataset is available. 


\subsection{STRUCTURE}

As a result of its complex geological history a large number of structural lineaments occur in the study area. The Omagh Thrust (GSNI, 1997) and Omagh Lineament (Earls et al. 1996b) were considered separately from other lineaments due to their regional influence and major importance as controls on the location and orientation of mineralisation in the study area (Figure 3). By treating these features separately in the analysis it was possible to weight them individually in the models. Other structural features, chiefly mapped faults and geophysical lineaments, with specific orientations based on empirical observations of structures at Curraghinalt and Cavanacaw, were also taken into account, as shown in Table 3. For each direction a window of $\pm 10^{\circ}$ was utilised so that vectors with orientations close to the specified direction were also taken into account in the analysis.

\subsection{GEOPHYSICS}

Aeromagnetic and electromagnetic (EM) data from the Tellus airborne survey were incorporated into the prospectivity analysis (Figure 7-9). Details of the survey specification are documented in the final processing report produced by BGS (Beamish et al. 2006). In addition BGS regional gravity data were included in this study as it is useful for identifying major regional crustal structures. The density of observations in this dataset for Northern Ireland is approximately 1 station per $1.25 \mathrm{~km}^{2}$.

A series of high-resolution regional images of the magnetic, electromagnetic and gravity data was produced for the study area. Geophysical images were analysed in ArcGIS and the main structural elements were identified and digitised on screen (Figure 11).

The main features digitised were as follows:

\section{Magnetic data}

- Lineaments related to faults and shear zones

- Lineaments attributed to dyke swarms

- Lineaments related to fold structures

- Postulated terrane boundaries

\section{Electromagnetic data}

- Principal EM conductors

- Anomaly offsets

\section{Gravity data}

- Gravity lineaments attributed to faults

- Deep seated faults 


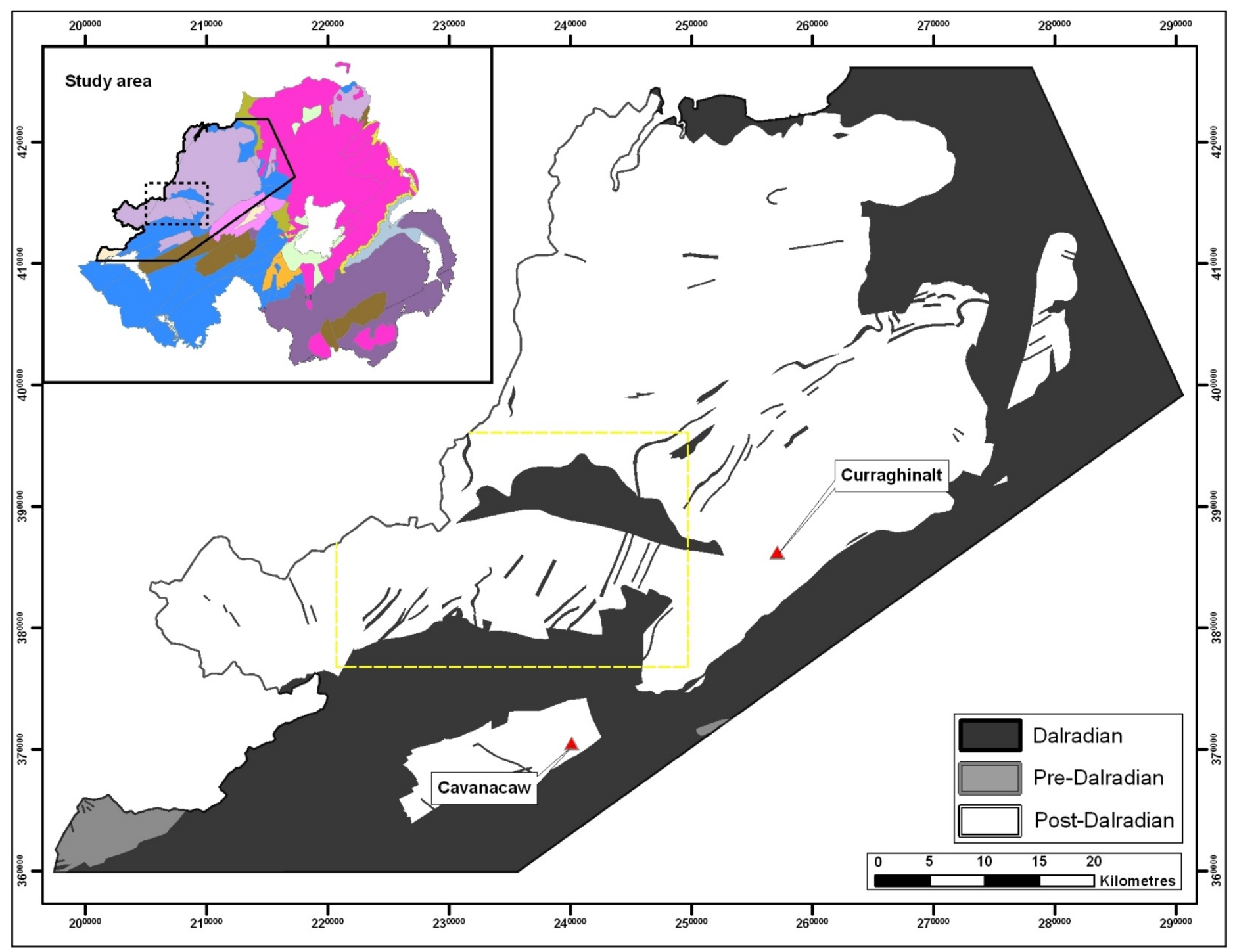

Figure 6 Generalised geology of the study area showing the groupings used in the prospectivity analysis. 


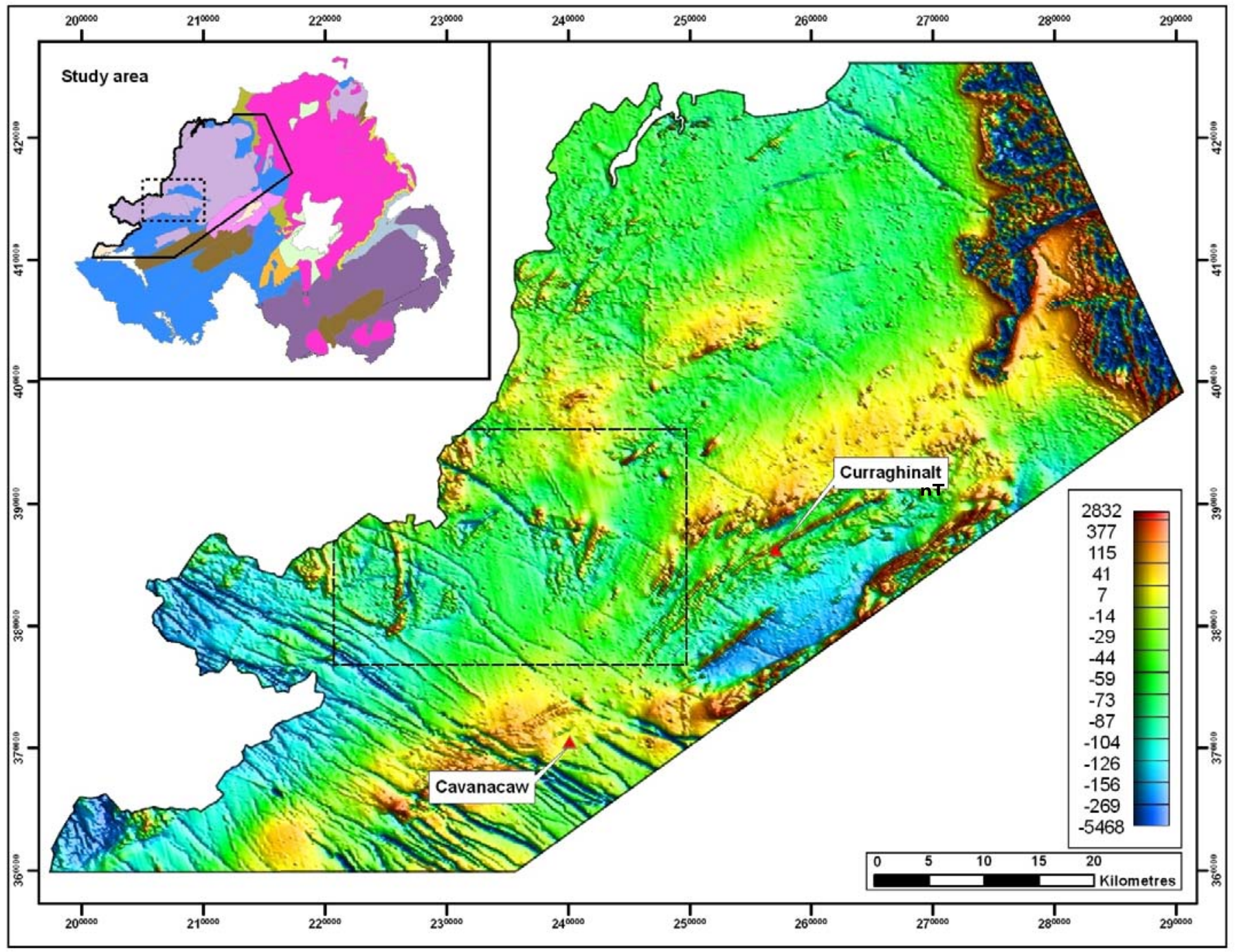

Figure 7 Reduced to pole magnetic anomaly map. 


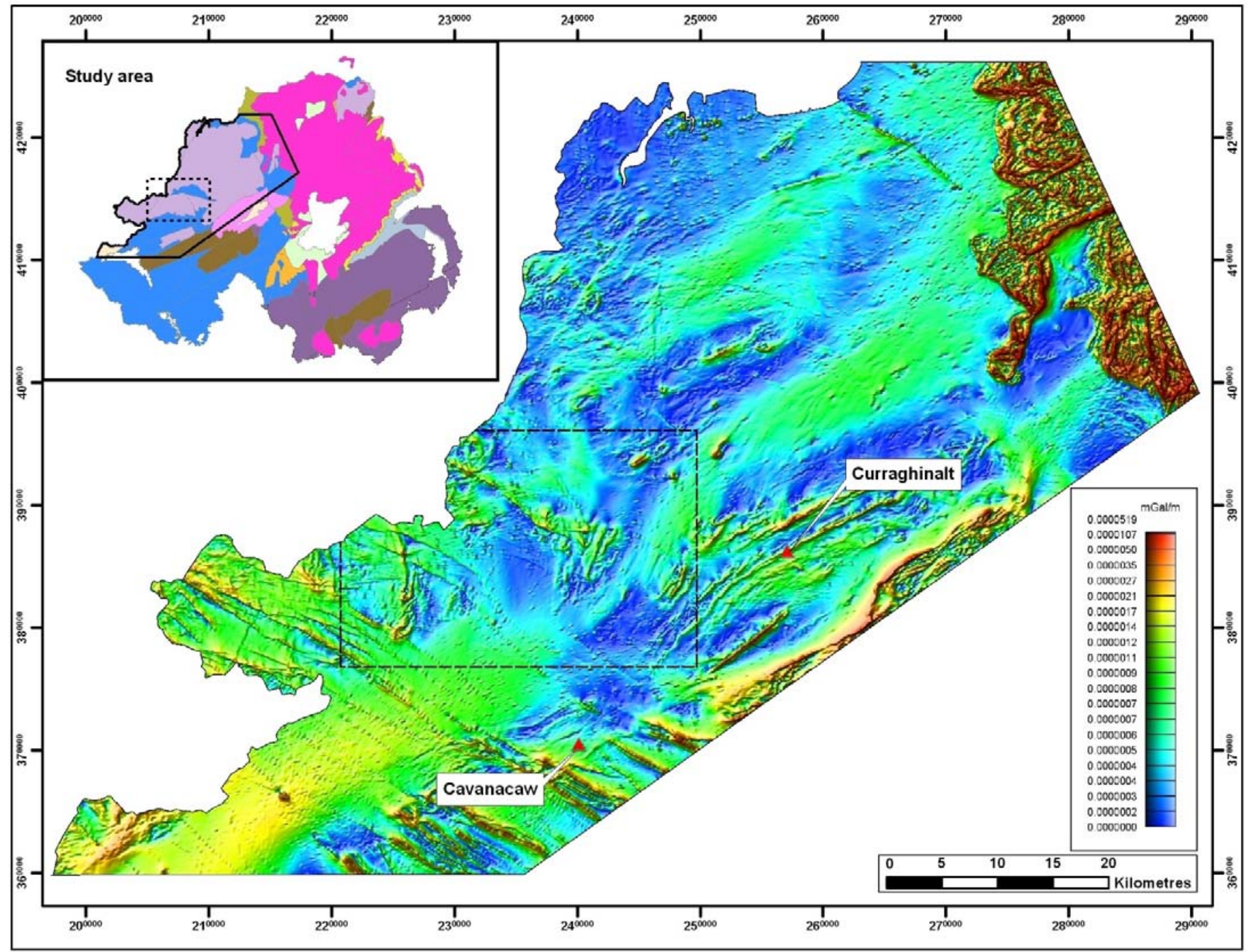

Figure 8 Magnetic pseudogravity horizontal gradient anomaly map. 


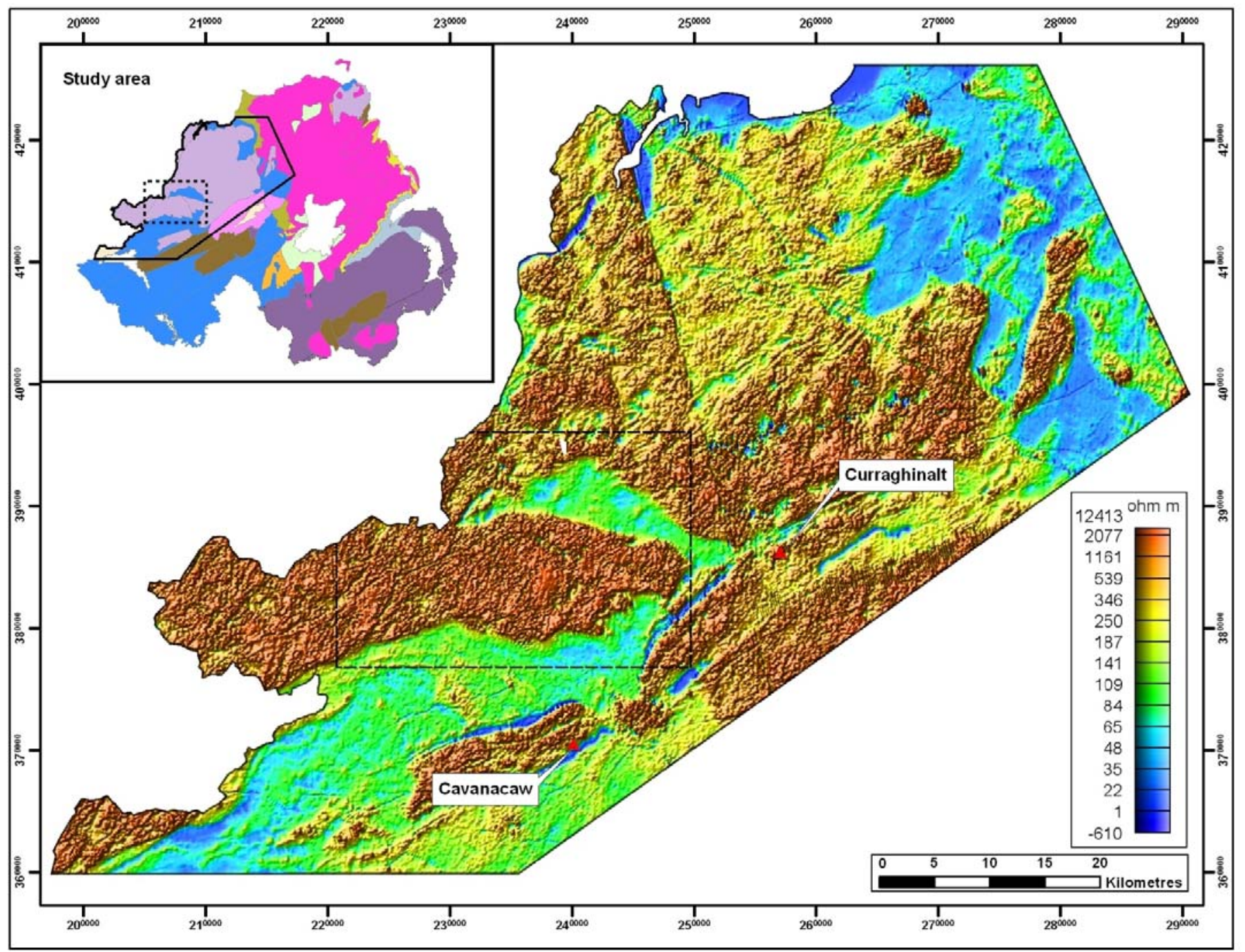

Figure 9 Electromagnetic field apparent resistivity anomaly map. 


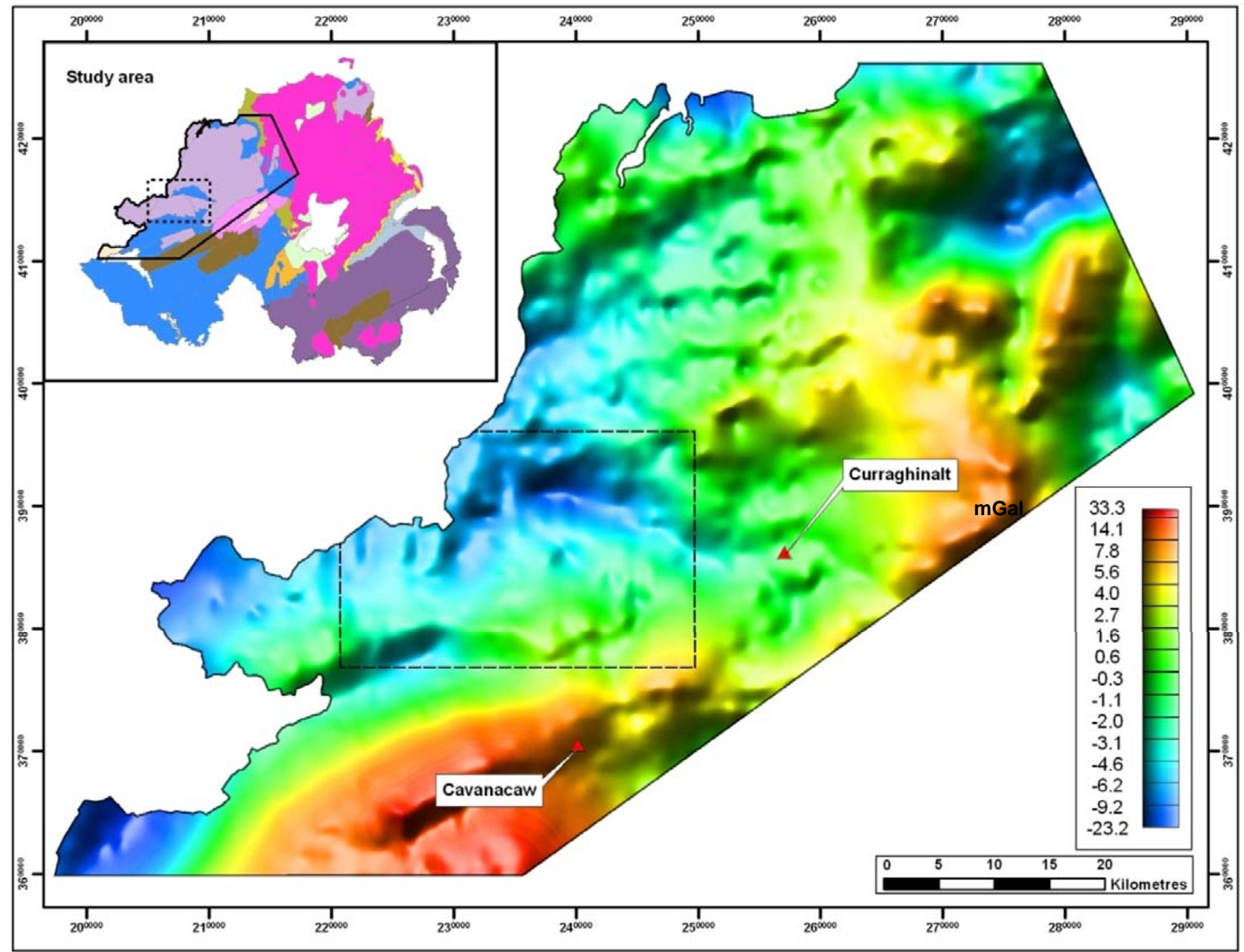

Figure 10 Residual Bouguer gravity anomaly map. 


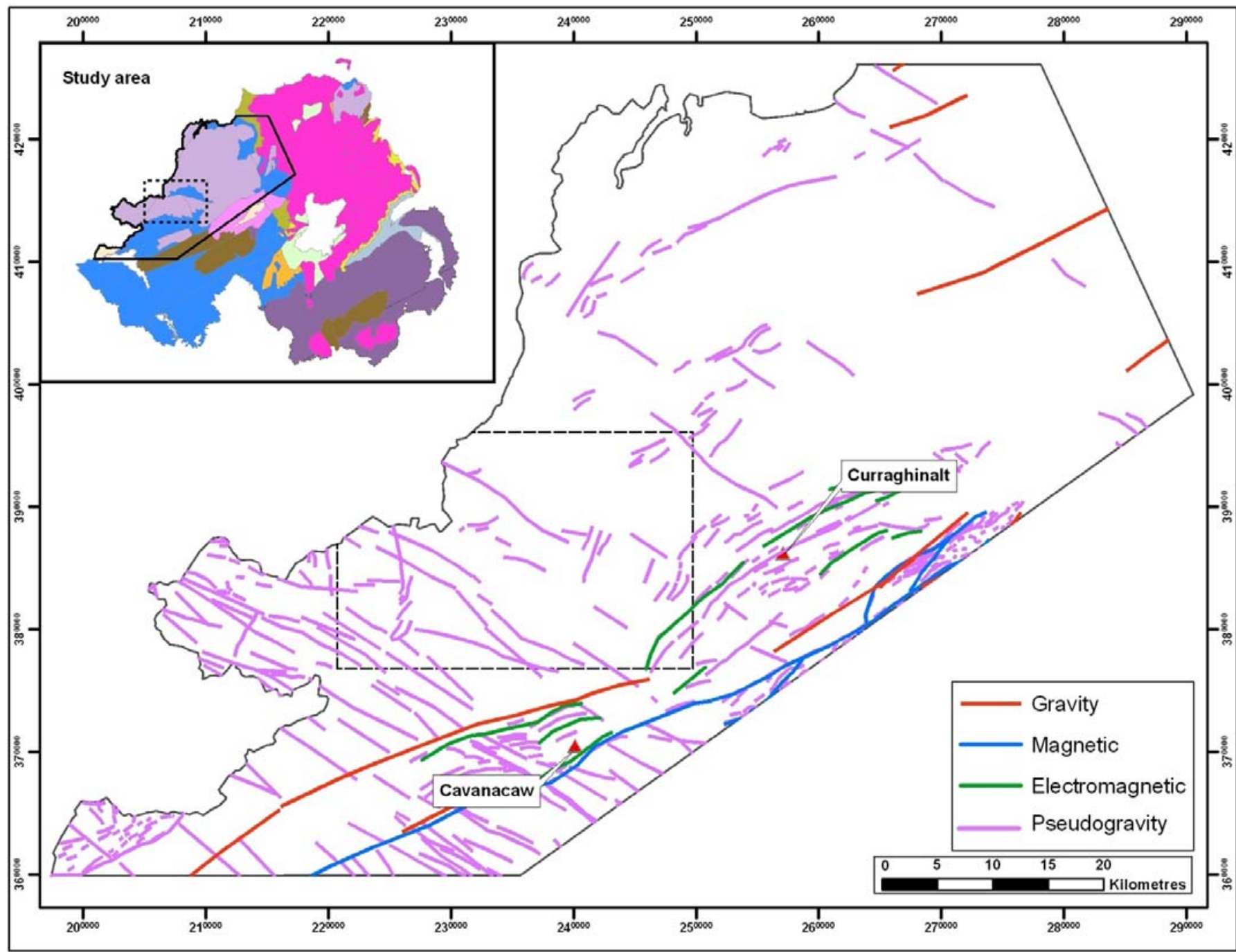

Figure 11 Digitised lineaments derived from the Tellus geophysical survey and the regional gravity dataset for the regional scale analysis. 


\subsubsection{Assessment of geophysical data for the Newtownstewart sheet}

For the purposes of the detailed prospectivity analysis a more detailed assessment of the geophysical data for the Newtownstewart sheet was undertaken (Figure 12). Lineaments were extracted from various magnetic images, chiefly the residual magnetic field derived by upward continuation to $500 \mathrm{~m}$, and the $1^{\text {st }}$ vertical derivative field. The lineaments reflect short wavelength near-surface features including magnetic horizons, fold structures and minor intrusions. Deeper magnetic bodies are not resolved in this way. Lineaments thought to be associated with dykes were principally represented by north-west-trending persistent, negative anomalies.

Several magnetic lineament trends exist on the Newtownstewart sheet. The majority of lineaments occur along the margins of local, often linear, magnetic units within Dalradian rocks especially the Dart Formation where they are spatially associated with grits and psammites. The north-east-trending lineaments north of the Newtownstewart Basin parallel the Dalradian outcrop in this area. Likewise north-north-east-trending lineaments south of the Newtonstewart Basin are consistent with the Dalradian strike in this region. In the western part of the area lineaments are more typically aligned north-south mirroring the strike of the Dalradian. In addition sinuous magnetic bands cutting across the Dalradian outcrop may reflect fold structures. A belt of northwest-trending, short to intermediate length lineaments cross cut the Dalradian outcrop and the Newtonstewart Basin. It is unclear whether these are dyke-related or mark a structural trend. Magnetic anomalies are also associated with pelitic and also conductive rocks of the Glengawana and Glenelly Formations in the south-eastern part of the Newtonstewart sheet. These occur at the western end of a persistent belt of arcuate anomalies related to shear zones within the Omagh Thrust zone.

The EM data was re-analysed using additional images to resolve anomalies within both low and high conductivity areas. A first vertical derivative EM map was also produced to show the margins of the main conductors. In general the Dalradian rocks within the Newtownstewart sheet are resistive, in contrast with the sandstones of the Roe Valley and Omagh Sandstone Group and the Claragh Sandstone Formation which are generally conductive with local areas of highly conductive rocks.

A series of prominent, persistent, arcuate linear conductors occurs within the Newtonstewart sheet. The most northerly of these is associated with the bounding fault of the Newtonstewart Basin along the southern margin of the Barony Glen Formation where it is in contact with the Dalradian Dart Formation to the south. Of note is the rapid change in strike of the lineament from west-north-west to south-west consistent with the outcrop trend. This conductor is thought to be fault-related. A second parallel arcuate lineament approximately $2.5 \mathrm{~km}$ to the south cuts across the Dart Formation but has no obvious geological expression. This could be interpreted as a second major fault or shear zone that has not been mapped. An additional four arcuate, parallel lineaments depicting an abrupt change in strike occur within the Claragh Sandstone Formation.

To the extreme south-east of the Newtownstewart area a series of north-east-trending lineaments occur within the Mullaghcarn and Glengawna Formations attributed to relatively thin conductive, pelitic units within the Dalradian rocks and/or faults or shear zones. The minor gold deposit at Rylagh coincides with one of these lineaments.

To the north of the Newtonstewart Basin shorter east-north-east-trending EM lineaments are distributed throughout the Dalradian rocks, reflecting local marked variations in the conductivity. Several of these persist into the younger rocks of the Newtonstewart Basin. There is a notable absence of these lineaments in the Dart Formation to the south of the Newtonstewart Basin. To the west of the area a set of linear north-east-trending conductors appears to be related to the Pettigoe Fault. 


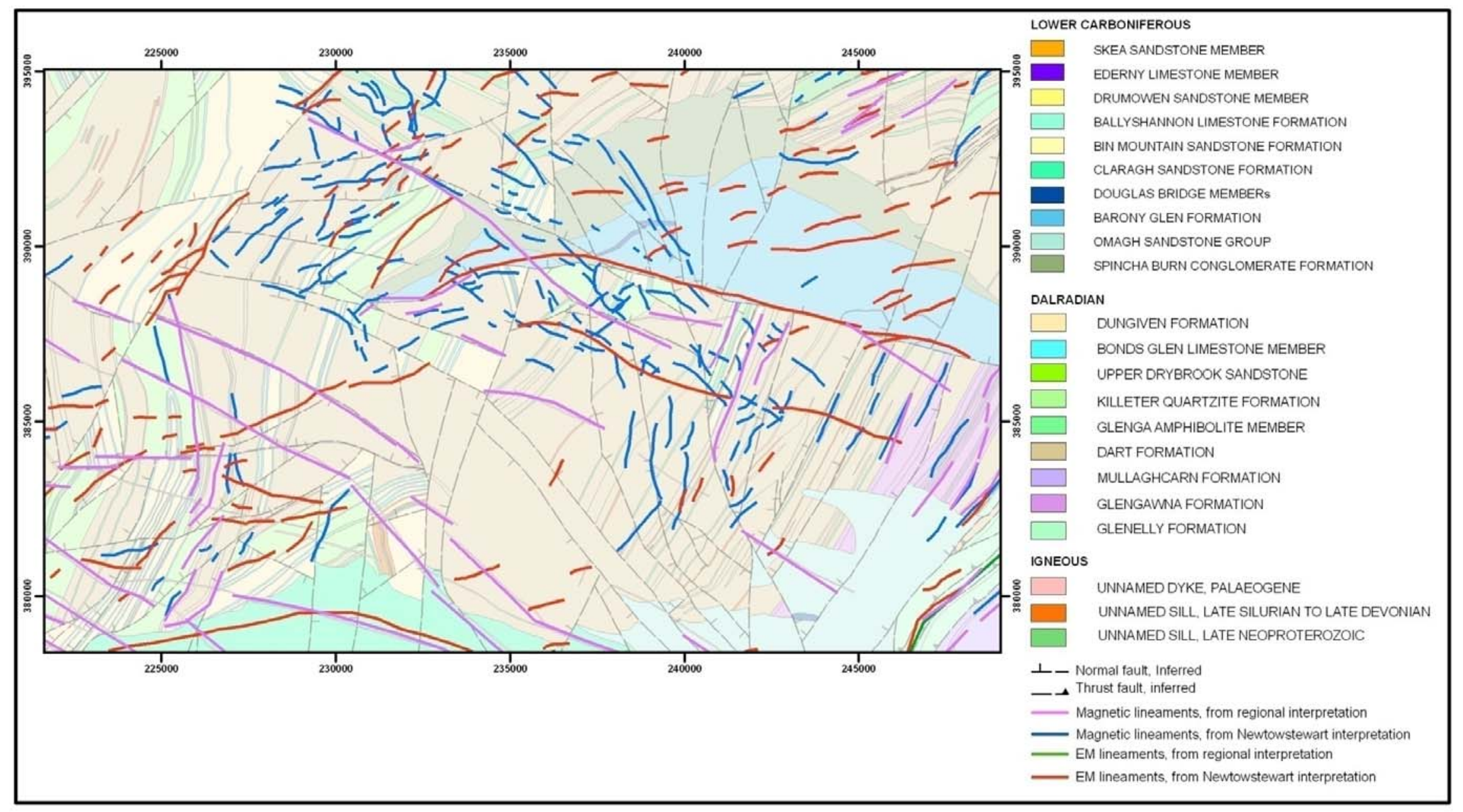

Figure 12 Lineaments derived from the Tellus geophysical data over the Newtownstewart map sheet. 


\subsection{GEOCHEMISTRY}

Stream-sediment geochemical data from the Tellus survey was incorporated in the prospectivity analysis. Standard BGS methodology based on -100 mesh $(<150 \mu \mathrm{m})$ samples was utilised throughout the field, laboratory and data processing stages of the geochemical survey (Johnson et al. 2005). The basic premise underlying the use of stream sediments in mineral exploration is that they are composite samples produced by erosion and weathering and thus represent the source catchment area of the stream drainage network. Samples were collected from first- and second-order stream over eastern Northern Ireland at an average density of 1 sample per $2.15 \mathrm{~km}^{2}$. For western Northern Ireland data from stream-sediment samples (39 analytes) collected in a previous programme which ran between 1994 and 1996 have been integrated with the new Tellus dataset and have been used in the present study.

It is important to note that the composition of stream-sediment samples reflects the bedrock geology of the catchment area, overburden cover and any contained metalliferous mineralisation. The choice of elements used in this analysis has been guided by the target mineral deposit type, and by a review of previous work on the lithogeochemistry of the mineralisation and related stream-sediment data. The geochemical data has not been normalised to catchment geology to remove the effects of varying bedrock geology. However, the data assessment has been carried out on the basis of knowledge of the element concentrations expected to be present in unmineralised lithologies of the types present in the study area. Gridded geochemical maps, based on percentiles, were created for each of the elements used in the analysis (Table 3, Figures 13-18). 1476 stream-sediment sample sites are located within the regional study area whilst 214 fall within the detailed area of the Newtownstewart sheet.

\begin{tabular}{|l|l|l|l|l|l|l|l|l|}
\hline Element & Count & Maximum & Mean & Median & $\mathbf{9 0 \%}$ & $\mathbf{9 5 \%}$ & $\mathbf{9 8 \%}$ & $\mathbf{9 9 \%}$ \\
\hline $\mathrm{Au}$ & 1376 & 3485 & 18 & 1 & 8 & 25 & 91 & 350 \\
\hline $\mathrm{Ag}$ & 1474 & 9 & 0.7 & 0.5 & 1 & 2 & 3 & 5 \\
\hline $\mathrm{As}$ & 1474 & 1400 & 27 & 12 & 57 & 96 & 150 & 231 \\
\hline $\mathrm{Cu}$ & 1474 & 162 & 31 & 26 & 58 & 71 & 87 & 94 \\
\hline $\mathrm{Pb}$ & 1474 & 207 & 37 & 33 & 54 & 65 & 76 & 93 \\
\hline $\mathrm{Zn}$ & 1474 & 1524 & 140 & 123 & 226 & 291 & 394 & 477 \\
\hline $\mathrm{Bi}$ & 1474 & 2.3 & 0.35 & 0.25 & 0.7 & 0.8 & 1.1 & 1.3 \\
\hline $\mathrm{Ba}$ & 1474 & 5905 & 758 & 710 & 1260 & 1497 & 1837 & 2533 \\
\hline
\end{tabular}

Table 5 Summary statistics for selected elements in Tellus stream-sediment samples for the study area. All values in ppm, except Au in ppb. 


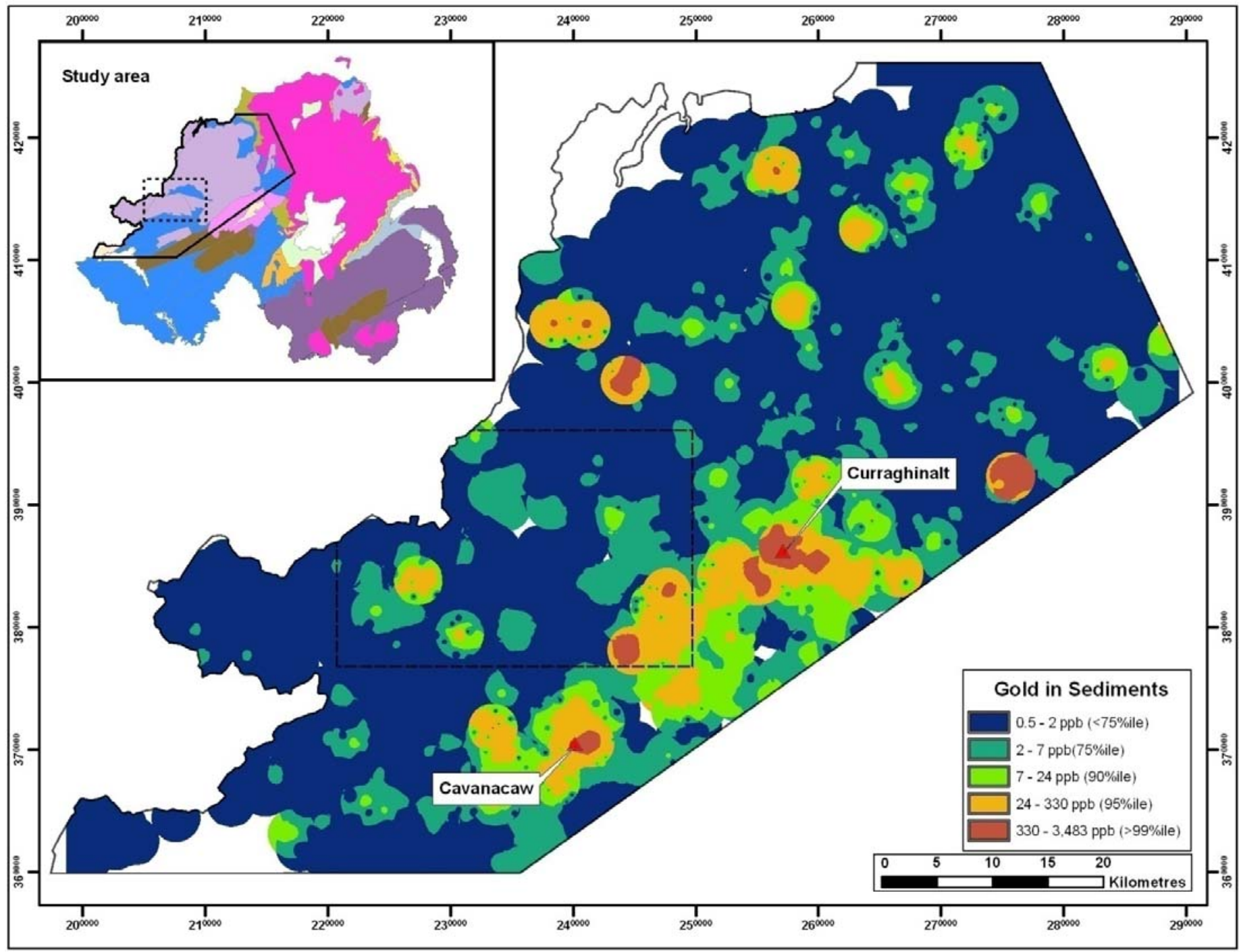

Figure 13 The distribution of gold in Tellus stream-sediment samples. 


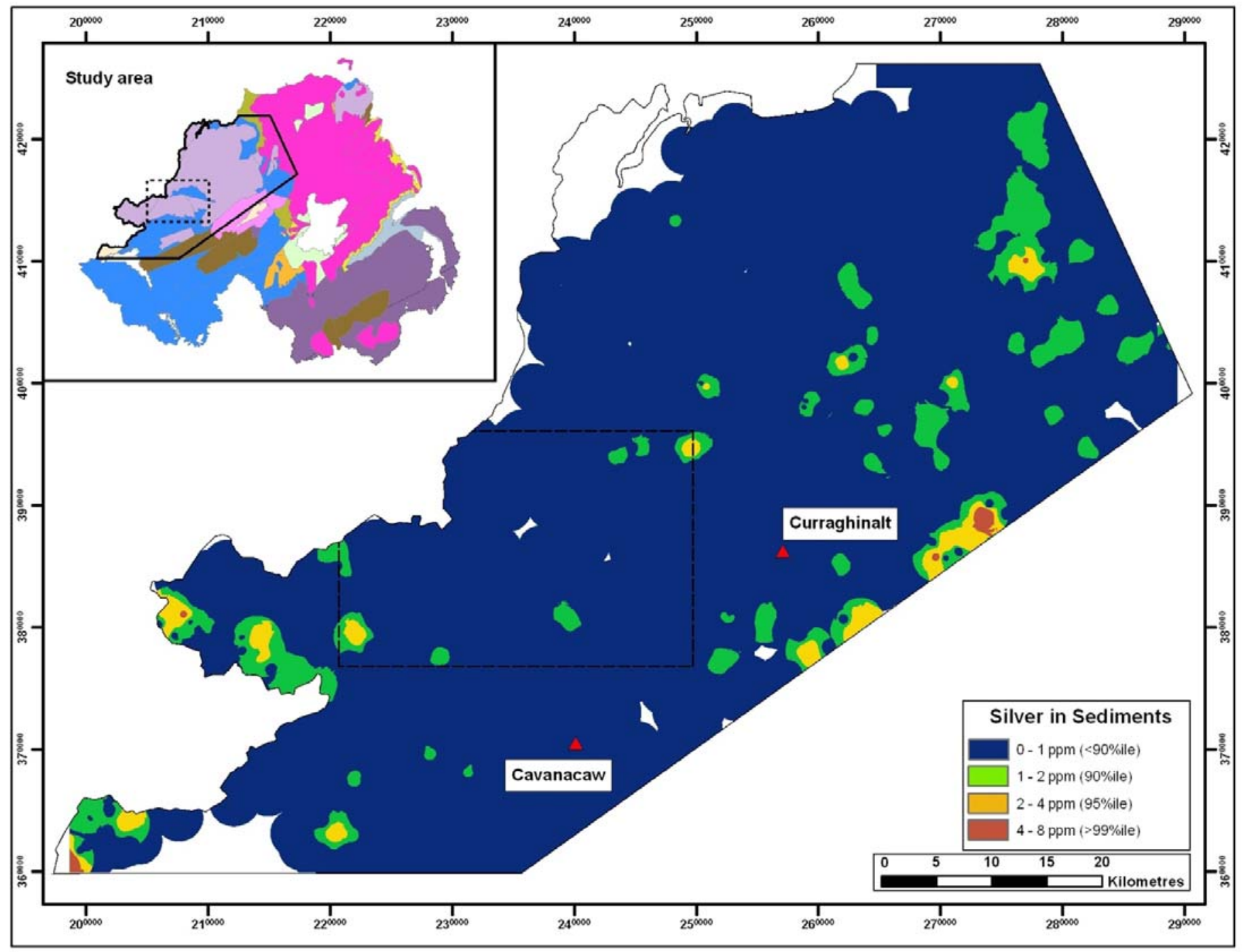

Figure 14 The distribution of silver in Tellus stream-sediment samples. 


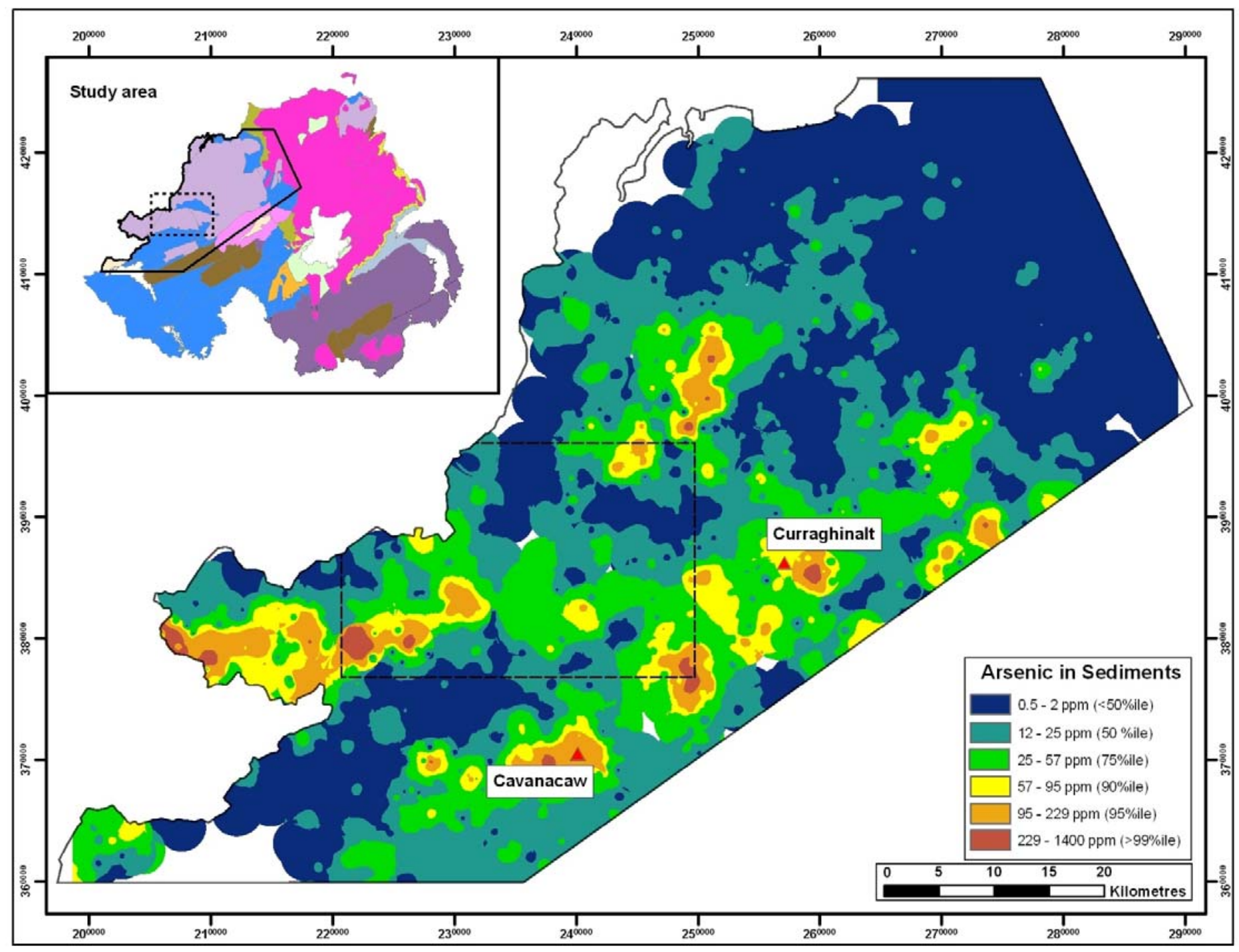

Figure 15 The distribution of arsenic in Tellus stream-sediment samples. 


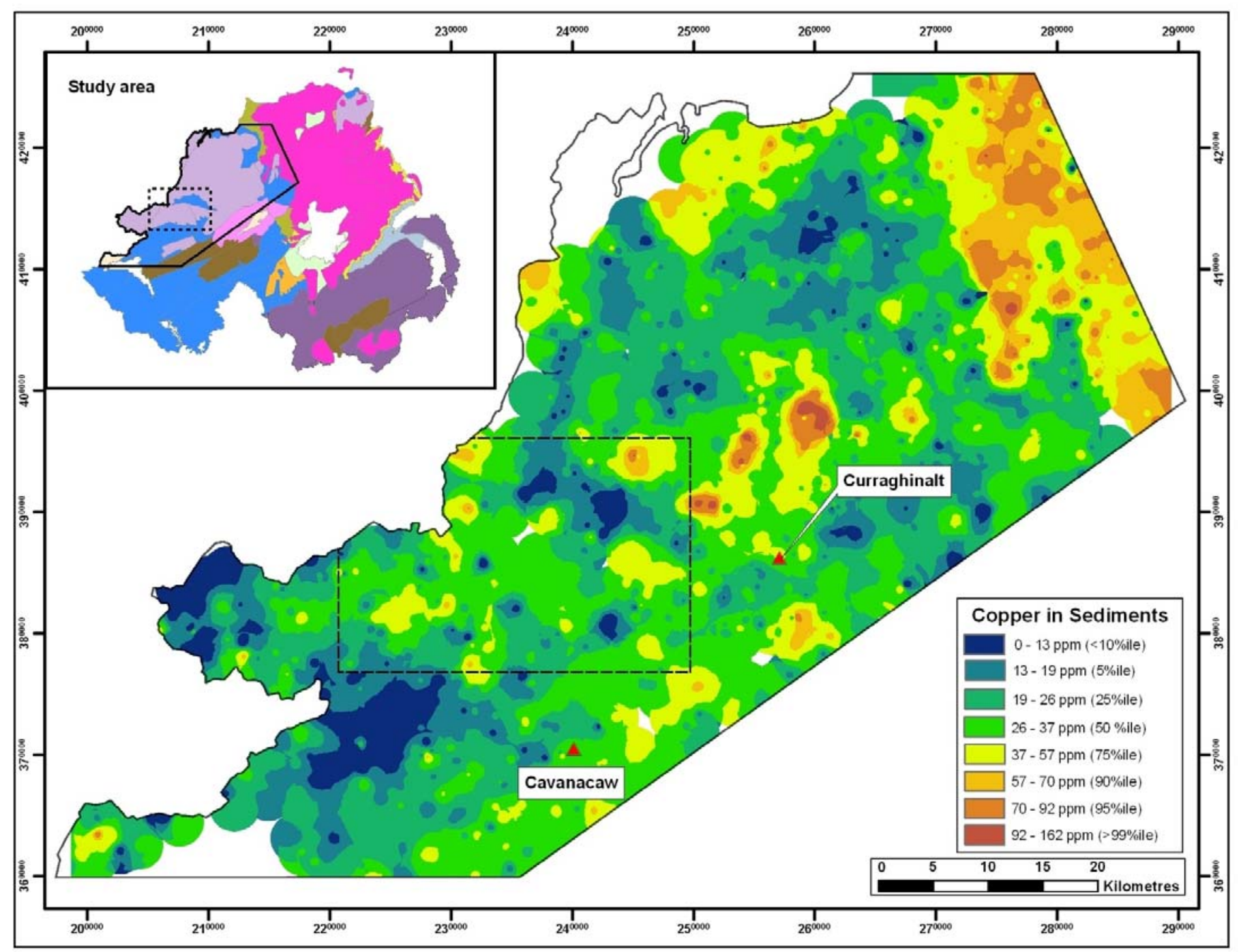

Figure 16 The distribution of copper in Tellus stream-sediment samples. 


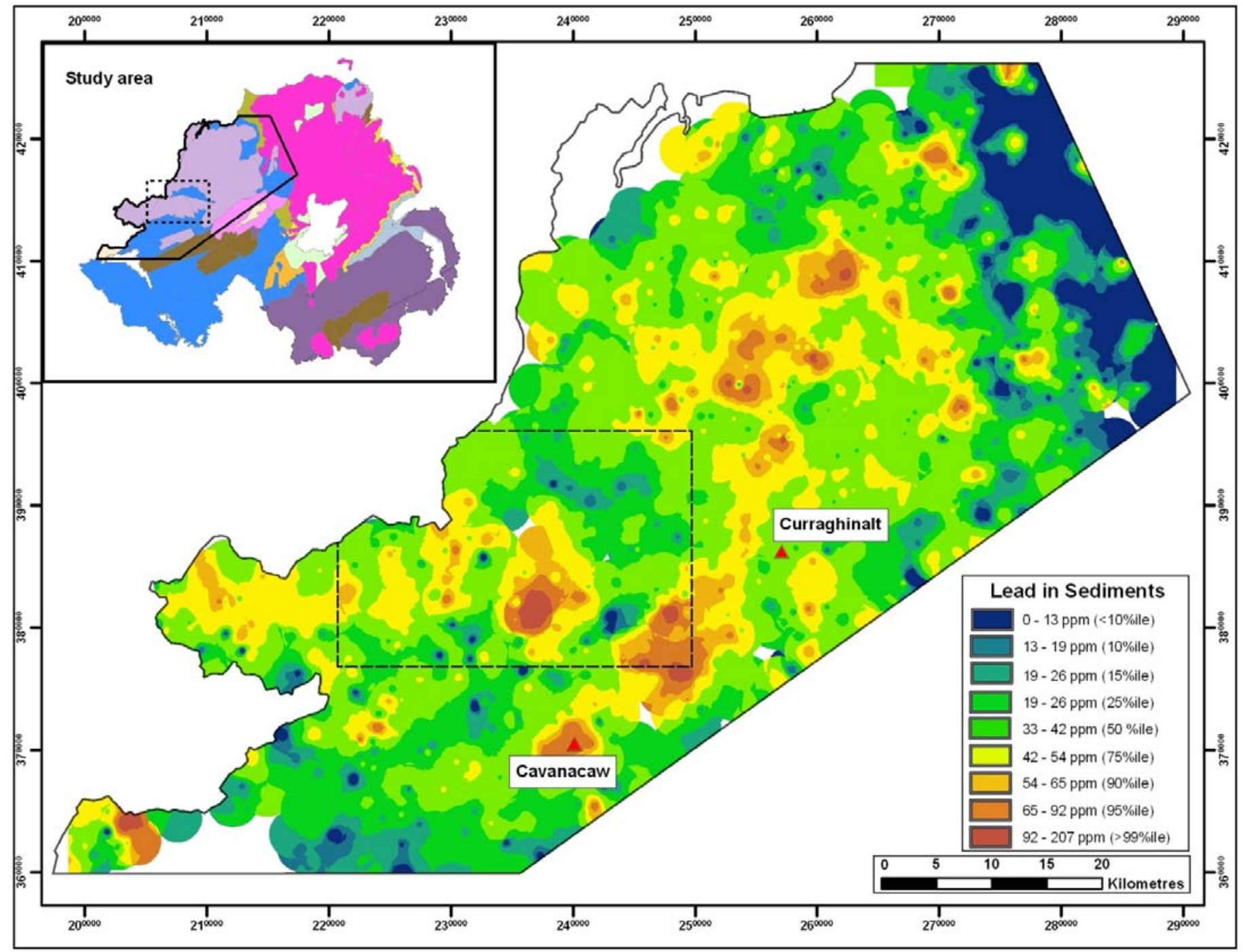

Figure 17 The distribution of lead in Tellus stream-sediment samples. 


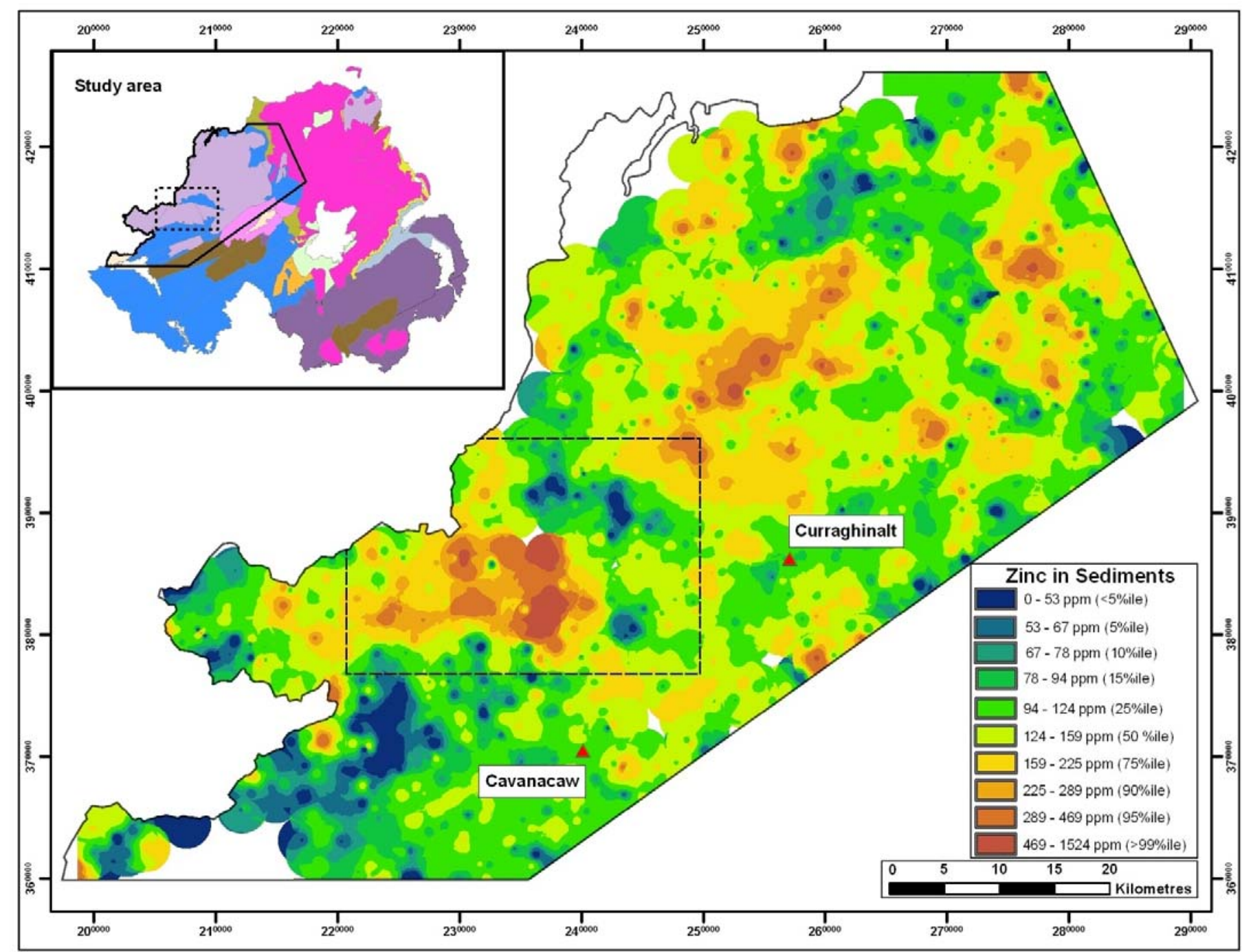

Figure 18 The distribution of zinc in Tellus stream-sediment samples. 


\subsection{MINERAL OCCURRENCES}

Mineral occurrences from the Northern Ireland MINLOCS Database were incorporated into the prospectivity analysis. The occurrences were grouped by significance into:

1. metallic sulphides-oxides-carbonates and sulphates in bedrock (excluding hematite);

2. metallic sulphides-oxides-carbonates and sulphates in float (excluding hematite); and

3. gangue mineral occurrences.

The quality of data in the MINLOCS database is highly variable, with entries ranging from detailed descriptions, such as 'disseminated galena in mica schist with associated graphitic schist', to vague and less informative statements, such as 'minor antimony'. In addition many of the records refer to disseminated pyrite. Given its abundance in metamorphic terranes and widespread distribution in the study area, potentially derived from diagenetic processes, pyrite occurrences were not considered to be significant exploration criteria. Accordingly a low weighting was assigned to these records in the prospectivity analysis. It was decided not include occurrences of gold in bedrock or alluvium from the MINLOCS Database in the analysis. However, observations of visible gold grains during collection of panned heavy mineral concentrates in the Tellus geochemical sampling were utilised in the analysis.

\section{Application of Fuzzy Logic modelling to the study area}

In Fuzzy Logic multi-class themes, such as maps, are classified on the basis of their mineral favourability using a fuzzy concept that allows favourability to be assigned on a continuous scale from $0 \cdot 0$ (non-membership) to $1 \cdot 0$ (full membership). For example, As values in a geochemical dataset may be divided according to percentile values, such that values above the $75 \%$ level in the cumulative dataset might be considered anomalous (Fuzzy set membership $=1 \cdot 0$ ) while values below the 25\% level might be considered not anomalous (Fuzzy set membership $=0 \cdot 0$ ) Values between $25 \%$ and $75 \%$ would, therefore, be assigned values on a scale from $0 \cdot 1$ to $1 \cdot 0$.

Each evidential theme capable of being represented in the exploration model for vein gold mineralisation in Northern Ireland (Tables 2 and 3) was assigned a Fuzzy Membership value on the basis of the mineral deposit model discussed in Section 4 (Table 6, 7, 8, 9, 10 and 11). The weighting applied is dependent on the relative importance and reliability of one data set against another. Areas without any favourable features, primarily due to lack of sufficient data, were assigned a no data value (99), the use of which signifies that the data has no impact on the model.

\begin{tabular}{|l|l|}
\hline Criteria & Fuzzy membership values \\
\hline Pre-Dalradian geology & $0.5 ;$ no range \\
\hline Dalradian geology & $0.7 ;$ no range \\
\hline Post-Dalradian geology & $0.3 ;$ no range \\
\hline
\end{tabular}

Table 6 Fuzzy membership values assigned to the simplified geology data theme in the initial modelling.

Following the initial modelling in which the geology theme was simplified into pre-Dalradian, Dalradian and post-Dalradian groupings (Table 6) two versions of the model were run with different fuzzy membership values assigned to individual Dalradian Formations. In the first version (V1) (Table 7) model, the pre- and post-Dalradian geology were given the same fuzzy 
membership values as in the original modelling (Table 6), whilst, the Dalradian was subdivided in a linear manner between 0.70 (Glengawna Formation) and 0.63 (e.g. Ballykelly Formation), in accordance with the ranking supplied by Garth Earls. This division allowed the prospectivity of individual Dalradian formations to be separated based on fuzzy membership value whilst still maintaining sufficient difference from pre-Dalradian rocks allocated a fuzzy membership value of 0.5. It was not considered appropriate to expand the fuzzy membership ranges (e.g. to 0.10.9 ) to give greater contrast between individual formations. This is because it was necessary to maintain consistency with fuzzy membership values assigned to other evidential themes e.g. structure, mineral occurrences etc. For example, if the Glengawna Formation, as a highly prospective formation, was allocated a fuzzy membership value of 0.9 this would be inconsistent with a gold in pan occurrence assigned a value of 0.7 .

\begin{tabular}{|c|c|c|c|}
\hline Formation name & $\begin{array}{l}\text { Earls ranking } \\
\text { (pers. } \\
\text { Comm.) }\end{array}$ & $\begin{array}{l}\text { Fuzzy } \\
\text { membership } \\
\text { value V1 }\end{array}$ & $\begin{array}{l}\text { Fuzzy } \\
\text { membership } \\
\text { value V2* }\end{array}$ \\
\hline Glengawna Formation & 10 & 0.70 & 0.70 \\
\hline Mullaghcarn Formation & 8 & 0.68 & 0.61 \\
\hline Dungiven Formation (carbonates) & 6 & 0.66 & 0.53 \\
\hline Dungiven Formation (non-carbonate) & 5 & 0.65 & 0.49 \\
\hline Glenelly Formation & 5 & 0.65 & 0.49 \\
\hline Dart Formation & 5 & 0.65 & 0.49 \\
\hline Newtownstewart Formation & 5 & 0.65 & 0.49 \\
\hline Londonderry Formation & 3 & 0.63 & 0.40 \\
\hline Ballykelly Formation & 3 & 0.63 & 0.40 \\
\hline Claudy Formation (Dart equivalent) & 5 & 0.65 & 0.49 \\
\hline Killeter Formation (Newtownstewart equivalent) & 5 & 0.65 & 0.49 \\
\hline Aghyaran formation (Dungiven equivalent) & 5 & 0.65 & 0.49 \\
\hline Mullyfa Formation (Dart equivalent) & 5 & 0.65 & 0.49 \\
\hline Lough Eske & 3 & 0.63 & 0.40 \\
\hline Lough Mourne & 3 & 0.63 & 0.40 \\
\hline $\begin{array}{l}\text { Croaghgarrow Formation (Glengawna } \\
\text { equivalent) }\end{array}$ & 10 & 0.70 & 0.70 \\
\hline Pre-Dalradian & $\mathrm{n} / \mathrm{a}$ & 0.50 & 0.40 \\
\hline Post-Dalradian & $\mathrm{n} / \mathrm{a}$ & 0.30 & 0.20 \\
\hline
\end{tabular}

Table 7 Fuzzy membership values assigned to the geology when intra-Dalradian rankings were incorporated in to the geology theme. *Incorporated into final model.

To improve the contrast between individual Dalradian formations, whilst retaining the relative significance of different evidential themes, a second version (V2) of the model was run. In this version an expanded range of fuzzy membership values was applied to all geological groupings, maintaining the maximum fuzzy logic value at 0.70 . The lowest ranking Dalradian formations and the pre-Dalradian geology were given the same fuzzy membership value (0.40), whilst the post-Dalradian geology was allocated a fuzzy membership of 0.20. Accordingly fuzzy membership values between 0.70 and 0.40 were applied, in a linear manner, to the individual Dalradian formations, in accordance with the relative rankings proposed by Garth Earls. This maintained the relative fuzzy memberships between the geology and other evidential themes, whilst improving the contrast between individual Dalradian formations (Figure 19). 
A proximity analysis ('buffering') was performed on linear features (faults, geophysical lineaments) (Figures 20-25) and point themes (mineral occurrences) (Figures 26-27) enabling decreasing weighting to be applied with distance from the feature. Features in each of the themes were buffered at variable intervals. The fuzzy memberships assigned to each buffer within each theme are shown in Tables 8 and 9.

The prospectivity map was created by combining each evidential theme using Fuzzy Logic operators in a series of steps, as depicted in the schematic inference model (Figure 28). Fuzzy memberships from each theme were combined using fuzzy operators to produce a gradational map of the mineral potential of the terrane.

Five operators have previously been found to be useful for the combination of exploration datasets (An et al. 1991): fuzzy AND, fuzzy OR, fuzzy algebraic product, fuzzy algebraic sum and fuzzy gamma operators (Table 12). The Fuzzy Logic operators used in this study to combine the fuzzy sets were selected on the basis of the relationships of the data layers and on the interdependence of the data. The maximum operator, fuzzy OR, was initially used to combine the mapped structures and interpreted geophysical lineaments. The fuzzy OR operator is used when two or more evidential themes represent the same evidence and the output membership values are controlled by the maximum values of any of the input maps (Bonham-Carter, 1994). Five derived maps were created for the structural vectors detailed in Table 8 and Figure 4 and an additional three maps based on the differentiated geology.

The primary and derived datasets were optimally combined to generate the final prospectivity map using the Fuzzy Gamma operator (Bonham-Carter and Graeme, 1994). The Fuzzy Gamma operator is defined in terms of Fuzzy algebraic sum. When $\gamma$ is 0 , the combination equals the fuzzy algebraic product and, when $\gamma$ is 1 , the combination is the same as fuzzy algebraic sum. Choice of $\gamma$ values produces output values that ensure a compromise between the 'increasive' nature of the fuzzy algebraic sum and the 'decreasive' effects of the fuzzy algebraic product. The effect of selecting different $\gamma$ values is discussed by Bonham-Carter (1994). Higher $\gamma$ values are generally used for combining exploration datasets because the increasive effects of larger values seem to reflect the subjective decision making of exploration geologists i.e. greater emphasis is generally placed upon higher values in mineral exploration. Accordingly a $\gamma$ value of 0.90 was selected for this analysis. 


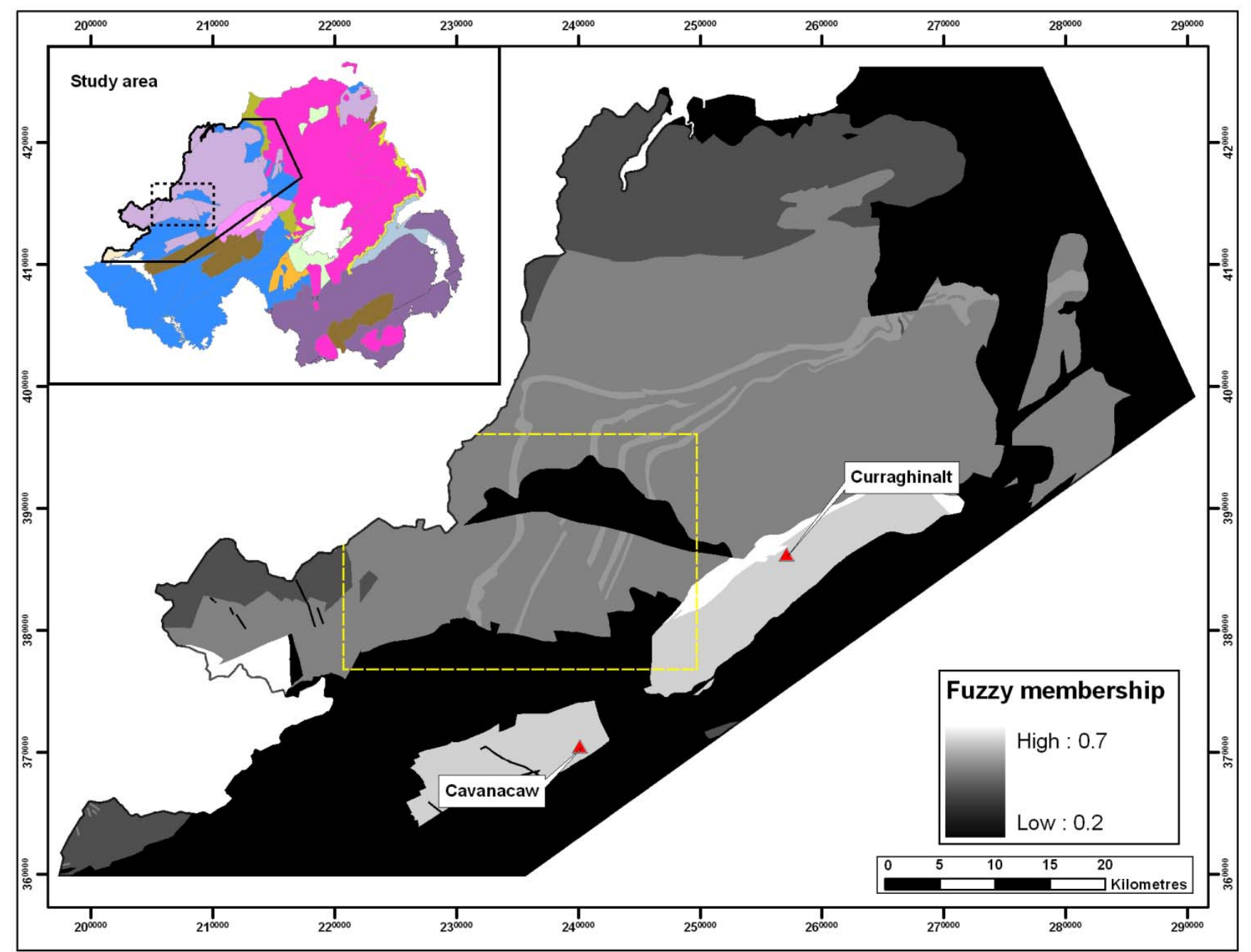

Figure 19 Allocation of Fuzzy membership values to Dalradian Formations. 


\begin{tabular}{|c|c|c|c|c|c|c|c|c|c|c|c|}
\hline \multicolumn{12}{|c|}{ Curraghinalt Regional } \\
\hline Percentiles & max. & $\begin{array}{c}100- \\
99\end{array}$ & 99-95 & $\begin{array}{c}\text { 95- } \\
90\end{array}$ & $90-75$ & $75-50$ & $\begin{array}{c}50- \\
25\end{array}$ & $\begin{array}{l}25- \\
15\end{array}$ & $15-10$ & $10-5$ & 5-0 \\
\hline $\begin{array}{l}\mathrm{Au}(\mathrm{ppb}) \\
\mathrm{Au} F \mathrm{~F}\end{array}$ & 3485 & $\begin{array}{l}330 \\
0.70\end{array}$ & $\begin{array}{l}24 \\
0.55\end{array}$ & $\begin{array}{l}7 \\
0.40\end{array}$ & $\begin{array}{l}2 \\
0.25\end{array}$ & 0.10 & 0.10 & 0.10 & 0.10 & 0.10 & 0.10 \\
\hline $\begin{array}{l}\text { As (ppm) } \\
\text { As FM }\end{array}$ & 1400 & $\begin{array}{l}229 \\
0.50\end{array}$ & $\begin{array}{l}95 \\
43\end{array}$ & $\begin{array}{l}57 \\
0.37\end{array}$ & $\begin{array}{l}25 \\
0.30\end{array}$ & $\begin{array}{l}12 \\
0.23\end{array}$ & $\begin{array}{l}2 \\
0.17\end{array}$ & 0.10 & 0.10 & 0.10 & 0.10 \\
\hline $\begin{array}{l}\text { Ag (ppm) } \\
\text { Ag FM }\end{array}$ & 9 & $\begin{array}{l}4 \\
0.60\end{array}$ & $\begin{array}{l}2 \\
0.43\end{array}$ & $\begin{array}{l}1 \\
0.27\end{array}$ & 0.10 & & & & & & \\
\hline $\begin{array}{l}\mathrm{Pb}(\mathrm{ppm}) \\
\mathrm{Pb} F M \\
\mathrm{Zn}(\mathrm{ppm})\end{array}$ & $\begin{array}{l}207 \\
1524\end{array}$ & $\begin{array}{l}93 \\
0.25 \\
469\end{array}$ & $\begin{array}{l}65 \\
0.23 \\
289\end{array}$ & $\begin{array}{l}54 \\
0.22 \\
225\end{array}$ & $\begin{array}{l}42 \\
0.20 \\
159\end{array}$ & $\begin{array}{l}33 \\
0.18 \\
124\end{array}$ & $\begin{array}{l}29 \\
0.17 \\
94\end{array}$ & $\begin{array}{l}26 \\
0.15 \\
78\end{array}$ & $\begin{array}{l}24 \\
0.13 \\
67\end{array}$ & $\begin{array}{l}1 \\
0.12 \\
53\end{array}$ & 0.10 \\
\hline Zn FM & & 0.20 & 0.19 & 0.18 & 0.17 & 0.16 & 0.14 & 0.13 & 0.12 & 0.11 & 0.10 \\
\hline $\begin{array}{l}\mathrm{Cu}(\mathrm{ppm}) \\
\mathrm{Cu} \mathrm{FM}\end{array}$ & 162 & $\begin{array}{l}92 \\
0.40\end{array}$ & $\begin{array}{l}70 \\
0.36\end{array}$ & $\begin{array}{l}57 \\
0.31\end{array}$ & $\begin{array}{l}37 \\
0.27\end{array}$ & $\begin{array}{l}26 \\
0.23\end{array}$ & $\begin{array}{l}19 \\
0.19\end{array}$ & & $\begin{array}{l}13 \\
0.14\end{array}$ & 0.10 & 0.10 \\
\hline \multicolumn{12}{|c|}{ Cavanacaw Regional } \\
\hline $\begin{array}{l}\text { Au (ppb) } \\
\mathrm{Au} F M\end{array}$ & 3485 & $\begin{array}{l}330 \\
0.70\end{array}$ & $\begin{array}{l}24 \\
0.55\end{array}$ & $\begin{array}{l}7 \\
0.40\end{array}$ & $\begin{array}{l}2 \\
0.25\end{array}$ & 0.10 & 0.10 & 0.10 & 0.10 & 0.10 & 0.10 \\
\hline $\begin{array}{l}\text { As (ppm) } \\
\text { As FM }\end{array}$ & 1400 & $\begin{array}{l}229 \\
0.60\end{array}$ & $\begin{array}{l}95 \\
0.52\end{array}$ & $\begin{array}{l}57 \\
0.43\end{array}$ & $\begin{array}{l}25 \\
0.35\end{array}$ & $\begin{array}{l}12 \\
0.27\end{array}$ & $\begin{array}{l}2 \\
0.18\end{array}$ & 0.10 & 0.10 & 0.10 & 0.10 \\
\hline $\begin{array}{l}\text { Ag (ppm) } \\
\text { Ag FM }\end{array}$ & 9 & $\begin{array}{l}4 \\
0.70\end{array}$ & $\begin{array}{l}2 \\
0.50\end{array}$ & $\begin{array}{l}1 \\
0.30\end{array}$ & 0.10 & & & & & & \\
\hline $\begin{array}{l}\mathrm{Pb}(\mathrm{ppm}) \\
\mathrm{Pb} F M\end{array}$ & 207 & $\begin{array}{l}93 \\
0.60\end{array}$ & $\begin{array}{l}65 \\
0.54\end{array}$ & $\begin{array}{l}54 \\
0.49\end{array}$ & $\begin{array}{l}42 \\
0.43\end{array}$ & $\begin{array}{l}33 \\
0.38\end{array}$ & $\begin{array}{l}29 \\
0.32\end{array}$ & $\begin{array}{l}26 \\
0.27\end{array}$ & $\begin{array}{l}24 \\
0.21\end{array}$ & $\begin{array}{l}21 \\
0.16\end{array}$ & 0.10 \\
\hline $\begin{array}{l}\text { Zn (ppm) } \\
\text { Zn FM }\end{array}$ & 1524 & $\begin{array}{l}469 \\
0.25\end{array}$ & $\begin{array}{l}289 \\
0.23\end{array}$ & $\begin{array}{l}225 \\
0.22\end{array}$ & $\begin{array}{l}159 \\
0.20\end{array}$ & $\begin{array}{l}124 \\
0.18\end{array}$ & $\begin{array}{l}94 \\
0.17\end{array}$ & $\begin{array}{l}78 \\
0.15\end{array}$ & $\begin{array}{l}67 \\
0.13\end{array}$ & $\begin{array}{l}53 \\
0.12\end{array}$ & 0.10 \\
\hline $\begin{array}{l}\mathrm{Cu}(\mathrm{ppm}) \\
\mathrm{Cu} \mathrm{FM}\end{array}$ & 162 & $\begin{array}{l}92 \\
0.40\end{array}$ & $\begin{array}{l}70 \\
0.36\end{array}$ & $\begin{array}{l}57 \\
0.31\end{array}$ & $\begin{array}{l}37 \\
0.27\end{array}$ & $\begin{array}{l}26 \\
0.23\end{array}$ & $\begin{array}{l}19 \\
0.19\end{array}$ & & $\begin{array}{l}13 \\
0.14\end{array}$ & 0.10 & 0.10 \\
\hline
\end{tabular}

Table 8 Fuzzy membership (FM) values assigned to each class within the geochemistry data theme for the Curraghinalt and Cavanacaw regional models. 


\begin{tabular}{|c|c|c|c|c|c|c|c|c|c|c|c|c|}
\hline \multicolumn{13}{|c|}{ Curraghinalt Local } \\
\hline Percentiles & max. & $100-99$ & $\begin{array}{c}99- \\
95\end{array}$ & $\begin{array}{c}95- \\
90\end{array}$ & $90-75$ & $75-50$ & $\begin{array}{c}50- \\
25\end{array}$ & $\begin{array}{c}25- \\
15\end{array}$ & $15-10$ & \multicolumn{2}{|c|}{$10-5$} & $5-0$ \\
\hline $\mathrm{Au}(\mathrm{ppb})$ & 1012 & 180 & 22 & 7 & 2.5 & & & & & \multirow{2}{*}{\multicolumn{2}{|c|}{0.10}} & \\
\hline $\mathrm{Au} F M$ & & 0.70 & 0.55 & 0.40 & 0.25 & 0.10 & 0.10 & 0.10 & 0.10 & & & 0.10 \\
\hline As Values & 965 & 430 & 120 & 74 & 36 & 17 & 10 & 8 & 7 & \multicolumn{2}{|l|}{5} & \\
\hline As FM & & 0.50 & 43 & 0.37 & 0.30 & 0.23 & 0.17 & 0.10 & 0.10 & \multicolumn{2}{|c|}{0.10} & 0.10 \\
\hline Ag (ppm) & 4 & 4 & 2 & 1 & & & & & & \multirow{2}{*}{\multicolumn{2}{|c|}{0.10}} & \\
\hline Ag FM & & 0.60 & 0.43 & 0.27 & 0.10 & 0.10 & 0.10 & 0.10 & 0.10 & & & 0.10 \\
\hline $\mathrm{Pb}(\mathrm{ppm})$ & 207 & 118.5 & 67.5 & 60.5 & 44.5 & 35.5 & 31.5 & 29.5 & & \multirow{2}{*}{\multicolumn{2}{|c|}{0.10}} & \\
\hline $\mathrm{Pb} F M$ & & 0.25 & 0.23 & 0.22 & 0.20 & 0.18 & 0.17 & 0.15 & 10 & & & 0.10 \\
\hline $\mathrm{Zn}(\mathrm{ppm})$ & 1524 & 665 & 327 & 243 & 178.5 & 136.5 & 97.5 & 79 & 62.5 & \multirow{2}{*}{\multicolumn{2}{|c|}{$\begin{array}{l}53 \\
0.11\end{array}$}} & \\
\hline Zn FM & & 0.20 & 0.19 & 0.18 & 0.17 & 0.16 & 0.14 & 0.13 & 0.12 & & & 0.10 \\
\hline $\mathrm{Cu}(\mathrm{ppm})$ & 103 & 72 & 54 & 45.5 & 32.5 & 25.5 & 17 & & & \multirow{2}{*}{\multicolumn{2}{|c|}{0.10}} & \\
\hline $\mathrm{Cu} F M$ & & 0.40 & 0.36 & 0.31 & 0.27 & 0.23 & 0.19 & 0.10 & 0.10 & & & 0.10 \\
\hline \multicolumn{13}{|c|}{ Cavanacaw Local } \\
\hline $\mathrm{Au}(\mathrm{ppb})$ & 1012 & 180 & 22 & 7 & 2.5 & & & & & \multirow[b]{2}{*}{0.10} & \multirow{2}{*}{\multicolumn{2}{|c|}{0.10}} \\
\hline $\mathrm{Au} F M$ & & 0.70 & 0.55 & 0.40 & 0.25 & 0.10 & 0.10 & 0.10 & 0.10 & & & \\
\hline As (ppm) & 965 & 430 & 120 & 74 & 36 & 17 & 10 & 8 & 7 & \multirow[b]{2}{*}{0.10} & \multirow{2}{*}{\multicolumn{2}{|c|}{0.10}} \\
\hline & & 0.60 & 0.52 & 0.43 & 0.35 & 0.27 & 0.18 & 0.10 & 0.10 & & & \\
\hline Ag (ppm) & 4 & 4 & 2 & 1 & & & & & & \multirow[b]{2}{*}{0.10} & \multirow{2}{*}{\multicolumn{2}{|c|}{0.10}} \\
\hline Ag FM & & 0.70 & 0.50 & 0.30 & 0.10 & 0.10 & 0.10 & 0.10 & 0.10 & & & \\
\hline $\mathrm{Pb}(\mathrm{ppm})$ & 207 & 118.5 & 67.5 & 60.5 & 44.5 & 35.5 & 31.5 & 29.5 & & \multirow[b]{2}{*}{0.10} & \multirow{2}{*}{\multicolumn{2}{|c|}{0.10}} \\
\hline $\mathrm{Pb} F M$ & & 0.60 & 0.54 & 0.49 & 0.43 & 0.38 & 0.32 & 0.27 & 0.10 & & & \\
\hline Zn (ppm) & 1524 & 665 & 327 & 243 & 178.5 & 136.5 & 97.5 & 79 & 62.5 & 53 & \multirow{2}{*}{\multicolumn{2}{|c|}{0.10}} \\
\hline Zn FM & & 0.25 & 0.23 & 0.22 & 0.20 & 0.18 & 0.17 & 0.15 & 0.13 & 0.12 & & \\
\hline $\mathrm{Cu}(\mathrm{ppm})$ & 103 & 72 & 54 & 45.5 & 32.5 & 25.5 & 17 & & & & \multirow{2}{*}{\multicolumn{2}{|c|}{0.10}} \\
\hline $\mathrm{Cu} F M$ & & 0.40 & 0.36 & 0.31 & 0.27 & 0.23 & 0.19 & & 0.14 & 0.10 & & \\
\hline
\end{tabular}

Table 9 Fuzzy membership (FM) values assigned to each class within the geochemistry data theme for the Curraghinalt and Cavanacaw detailed models.

\section{Regional structures}

\begin{tabular}{|c|c|c|c|c|c|c|c|c|c|c|c|}
\hline \multirow[b]{2}{*}{ Criterion } & \multirow[b]{2}{*}{ Model } & & \multicolumn{9}{|c|}{ Fuzzy membership values (between $0-1$ ) } \\
\hline & & $\begin{array}{l}\text { Buffer } \\
\text { distance } \\
\text { (km) }\end{array}$ & $\begin{array}{l}\mathbf{0 .} \\
\mathbf{0}- \\
1 . \\
0\end{array}$ & $\begin{array}{l}1.0- \\
2.0\end{array}$ & $\begin{array}{l}2.0- \\
3.0\end{array}$ & $\begin{array}{l}3.0- \\
4.0\end{array}$ & $\begin{array}{l}4.0- \\
5.0\end{array}$ & $\begin{array}{l}5.0- \\
6.0\end{array}$ & $\begin{array}{l}6.0- \\
7.0\end{array}$ & $\begin{array}{l}\text { 7.0- } \\
8.0\end{array}$ & \\
\hline $\begin{array}{l}\text { Omagh } \\
\text { Thrust }\end{array}$ & Curraghinalt & & $\begin{array}{r}0 . \\
70\end{array}$ & 0.61 & 0.53 & 0.44 & 0.36 & 0.27 & 0.19 & 0.10 & \\
\hline & Cavanacaw & & $\begin{array}{c}0 . \\
50\end{array}$ & 0.44 & 0.39 & 0.33 & 0.27 & 0.21 & 0.16 & 0.10 & \\
\hline Criterion & Model & $\begin{array}{l}\text { Buffer } \\
\text { distance } \\
(\mathbf{k m})\end{array}$ & $\begin{array}{l}0- \\
1\end{array}$ & $1-2$ & $2-4$ & 4-6 & 6-8 & 8-10 & $\begin{array}{l}10- \\
12\end{array}$ & $12-14$ & $\begin{array}{l}14- \\
16\end{array}$ \\
\hline $\begin{array}{l}\text { Basement } \\
\text { lineaments }\end{array}$ & Curraghinalt & & $\begin{array}{r}0 . \\
40\end{array}$ & 0.36 & 0.33 & 0.29 & 0.25 & 0.21 & 0.18 & 0.14 & 0.10 \\
\hline & Cavanacaw & & $\begin{array}{c}0 . \\
70\end{array}$ & 0.63 & 0.55 & 0.48 & 0.40 & 0.33 & 0.25 & 0.18 & 0.10 \\
\hline
\end{tabular}


$2^{\text {nd }}$ order structures

\begin{tabular}{|c|c|c|c|c|c|c|c|}
\hline \multirow[b]{2}{*}{ Criteria } & \multirow[b]{2}{*}{ Model } & \multicolumn{6}{|c|}{ Fuzzy membership values (between 0-1) } \\
\hline & & $\begin{array}{l}\text { Buffer } \\
(\mathbf{k m})\end{array}$ & distance & $0.0-0.5$ & $0.5-0.75$ & $0.75-1.0$ & 1.0-1.25 \\
\hline \multirow[t]{2}{*}{ NE-SW structures } & Curraghinalt & & & 0.60 & 0.43 & 0.27 & 0.1 \\
\hline & Cavanacaw & & & 0.45 & 0.33 & 0.22 & 0.1 \\
\hline \multirow[t]{2}{*}{$N$-S structures } & Curraghinalt & & & 0.40 & 0.30 & 0.20 & 0.1 \\
\hline & Cavanacaw & & & 0.70 & 0.50 & 0.30 & 0.1 \\
\hline $\begin{array}{l}E-W \text { to } E S E-W N W \\
\text { structures }\end{array}$ & Curraghinalt & & & 0.70 & 0.50 & 0.30 & 0.1 \\
\hline $\begin{array}{l}\text { SSE-NNW } \\
\text { structures }\end{array}$ & Cavanacaw & & & 0.50 & 0.40 & 0.30 & 0.1 \\
\hline $\begin{array}{l}\text { ENE-WSW } \\
\text { structures }\end{array}$ & Cavanacaw & & & 0.45 & 0.33 & 0.22 & 0.1 \\
\hline
\end{tabular}

Table 10 Fuzzy membership values assigned to each buffer around regional and second-order structures.

\begin{tabular}{|c|c|c|c|c|c|c|c|c|c|}
\hline & & \multicolumn{8}{|c|}{ Fuzzy membership values (between $0-1$ ) } \\
\hline Criteria & $\begin{array}{l}\text { Buffer distance } \\
(\mathrm{km})\end{array}$ & $\begin{array}{l}0.0- \\
0.5\end{array}$ & $\begin{array}{l}0.5- \\
1.0\end{array}$ & $\begin{array}{l}1.0- \\
1.5\end{array}$ & $\begin{array}{l}1.5- \\
2.0\end{array}$ & $\begin{array}{l}2.0- \\
2.5\end{array}$ & $\begin{array}{l}2.5- \\
3.0\end{array}$ & $\begin{array}{l}3.0- \\
3.5\end{array}$ & $\begin{array}{l}3.5- \\
4.0\end{array}$ \\
\hline $\begin{array}{l}\text { Tellus gold in } \\
\text { pans }\end{array}$ & & 0.70 & 0.61 & 0.53 & 0.44 & 0.36 & 0.27 & 0.19 & 0.10 \\
\hline \multicolumn{10}{|l|}{ MINLOCS } \\
\hline Group 1 & & \multicolumn{2}{|c|}{0.20} & \multicolumn{2}{|c|}{0.17} & & & \multicolumn{2}{|c|}{0.10} \\
\hline Group 2 & & \multicolumn{4}{|c|}{0.20} & \multicolumn{4}{|c|}{0.10} \\
\hline Group 3 & & 0.20 & 0.17 & 0.13 & 0.10 & & & & \\
\hline
\end{tabular}

Table 11 Fuzzy membership values assigned to each buffer around known mineral occurrences.

\begin{tabular}{|l|l|l|}
\hline Operator & Equation & Description \\
\hline Fuzzy AND & $\mu_{\text {combination }}=\operatorname{Min}\left(\mu_{\mathrm{A}}, \mu_{\mathrm{B}}, \mu_{\mathrm{C}}, \ldots\right)$ & Minimum operator \\
\hline Fuzzy OR & $\mu_{\text {combination }}=\operatorname{Max}\left(\mu_{\mathrm{A}}, \mu_{\mathrm{B}}, \mu_{\mathrm{C}}, \ldots\right)$ & Maximum operator \\
\hline Fuzzy algebraic product & $\mu_{\text {combination }}=\Pi^{n}{ }_{i=1}{ }^{\mu_{i}}$ & $\begin{array}{l}\text { Result is always smaller (or equal to) the } \\
\text { largest contributing fuzzy membership } \\
\text { value }\end{array}$ \\
\hline Fuzzy algebraic sum & $\mu_{\text {combination }}=1-\Pi^{n}{ }_{i=1}\left(1-{ }_{i}{ }_{i}\right)$ & $\begin{array}{l}\text { Result is always larger (or equal to) the } \\
\text { largest contributing fuzzy membership } \\
\text { value }\end{array}$ \\
\hline Fuzzy gamma $(\gamma)$ & $\mu_{\text {combination }}=\left(\Pi_{i=1}^{n}{ }_{i}{ }^{1-y}{ }^{1-y}\left(1-\Pi^{n}{ }_{i=1}\left(1-{ }_{i}{ }_{i}\right)\right)^{\gamma}\right.$ & $\begin{array}{l}\text { A combination of the fuzzy algebraic } \\
\text { product and the fuzzy algebraic sum }\end{array}$ \\
\hline
\end{tabular}

Table 12 Fuzzy Logic operators as described by Bonham-Carter (1994) and Nykanen et al. (2008) 


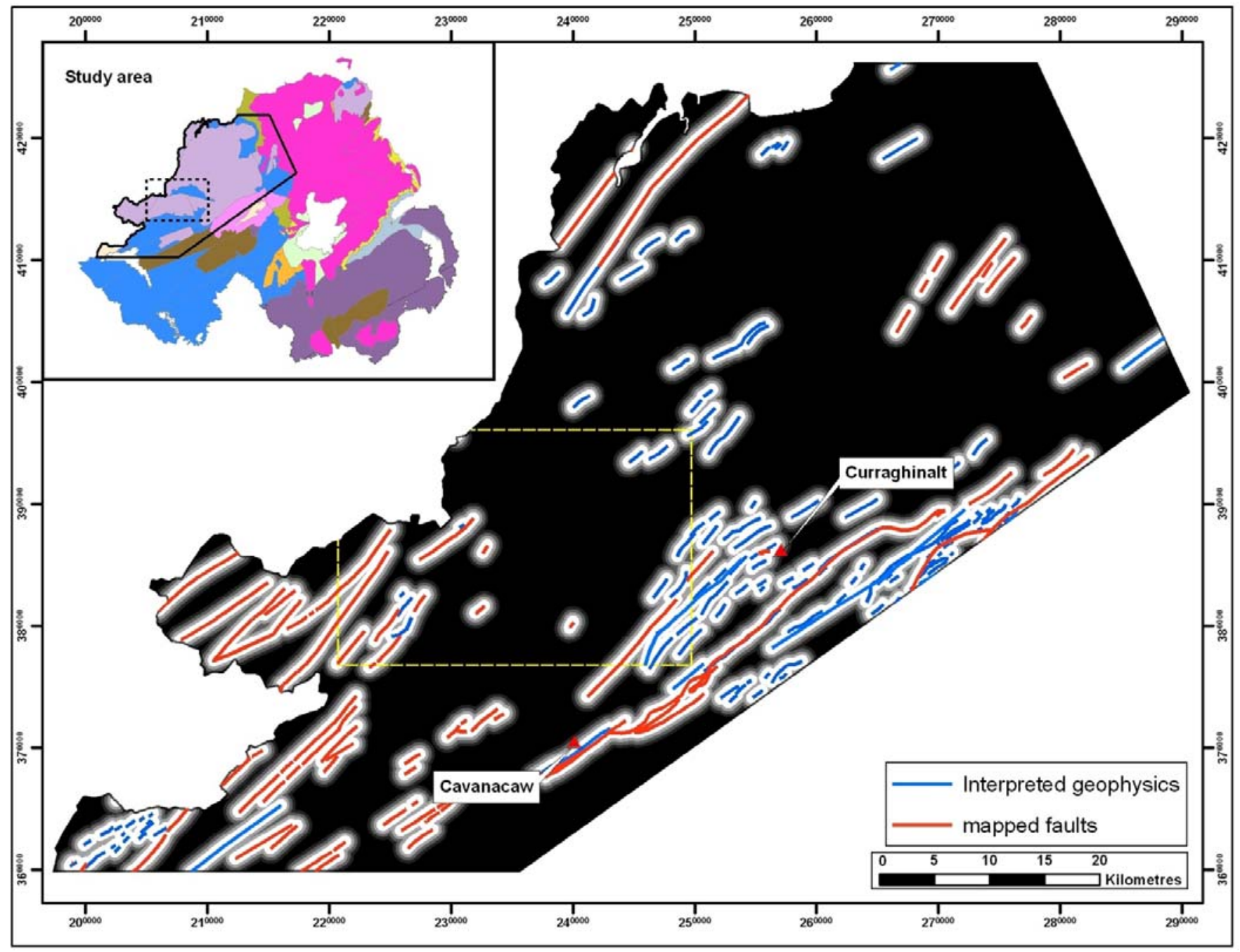

Figure 20 Buffered north-east-trending structures. 


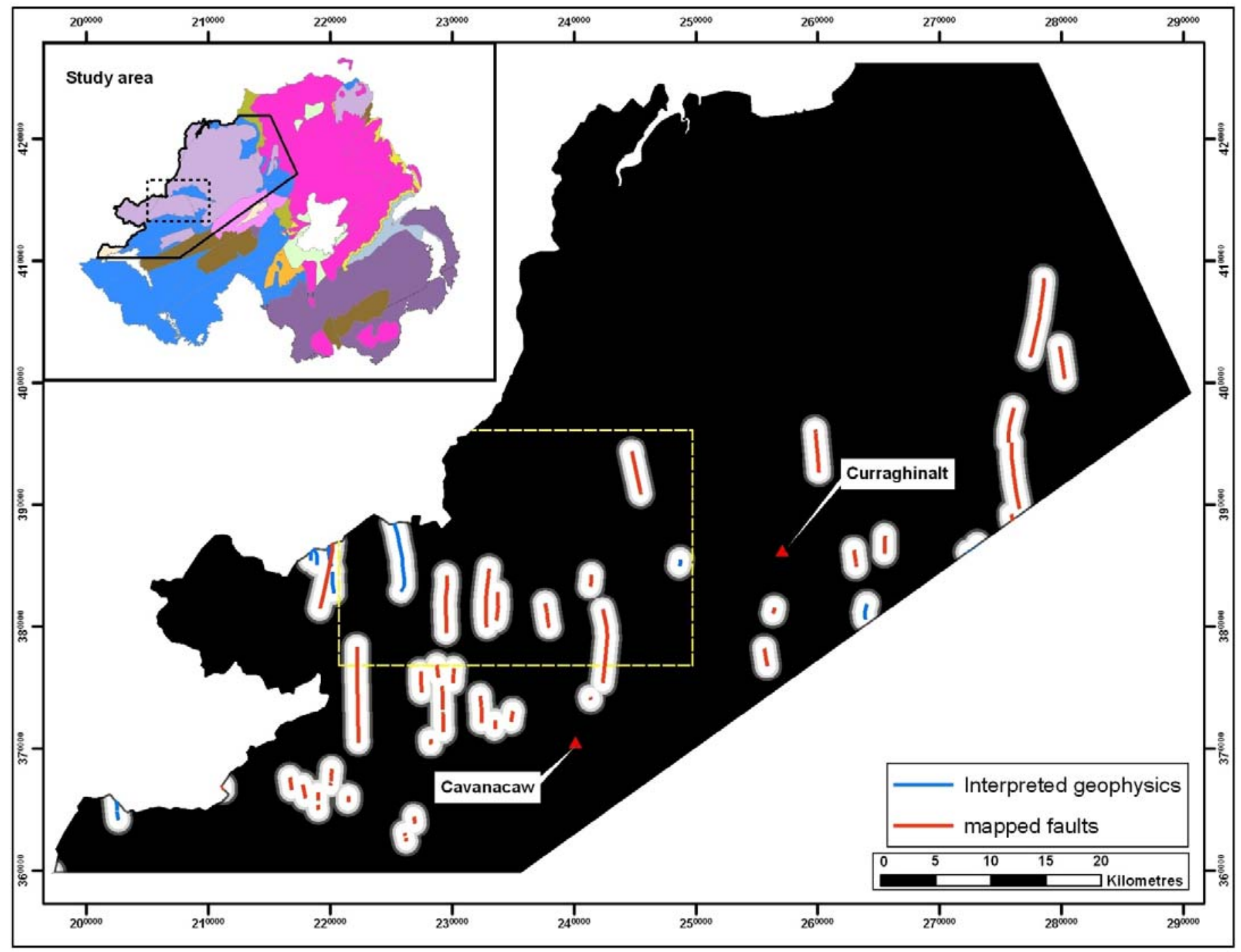

Figure 21 Buffered north-south-trending structures. 


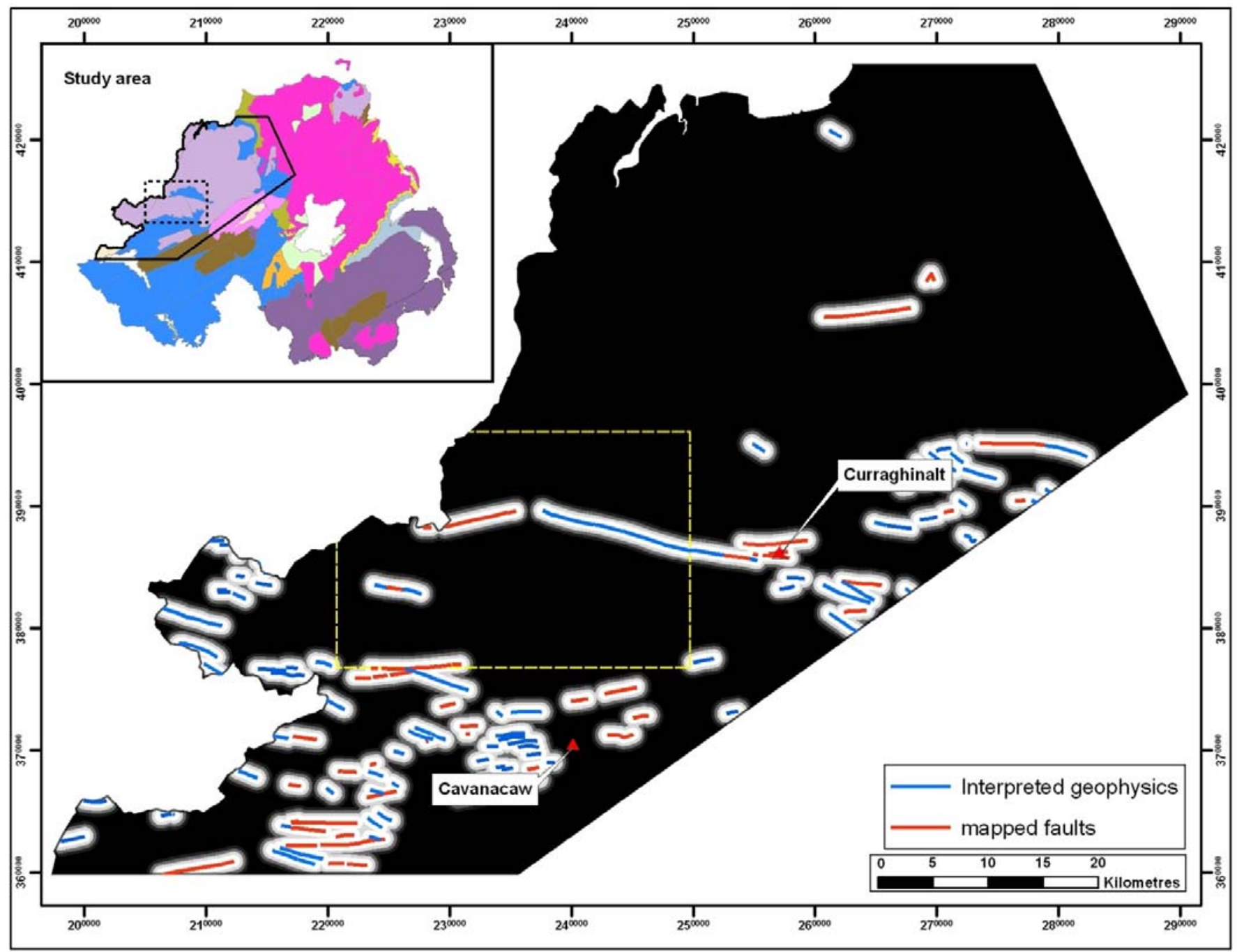

Figure 22 Buffered east- to east-south-east-trending structures. 


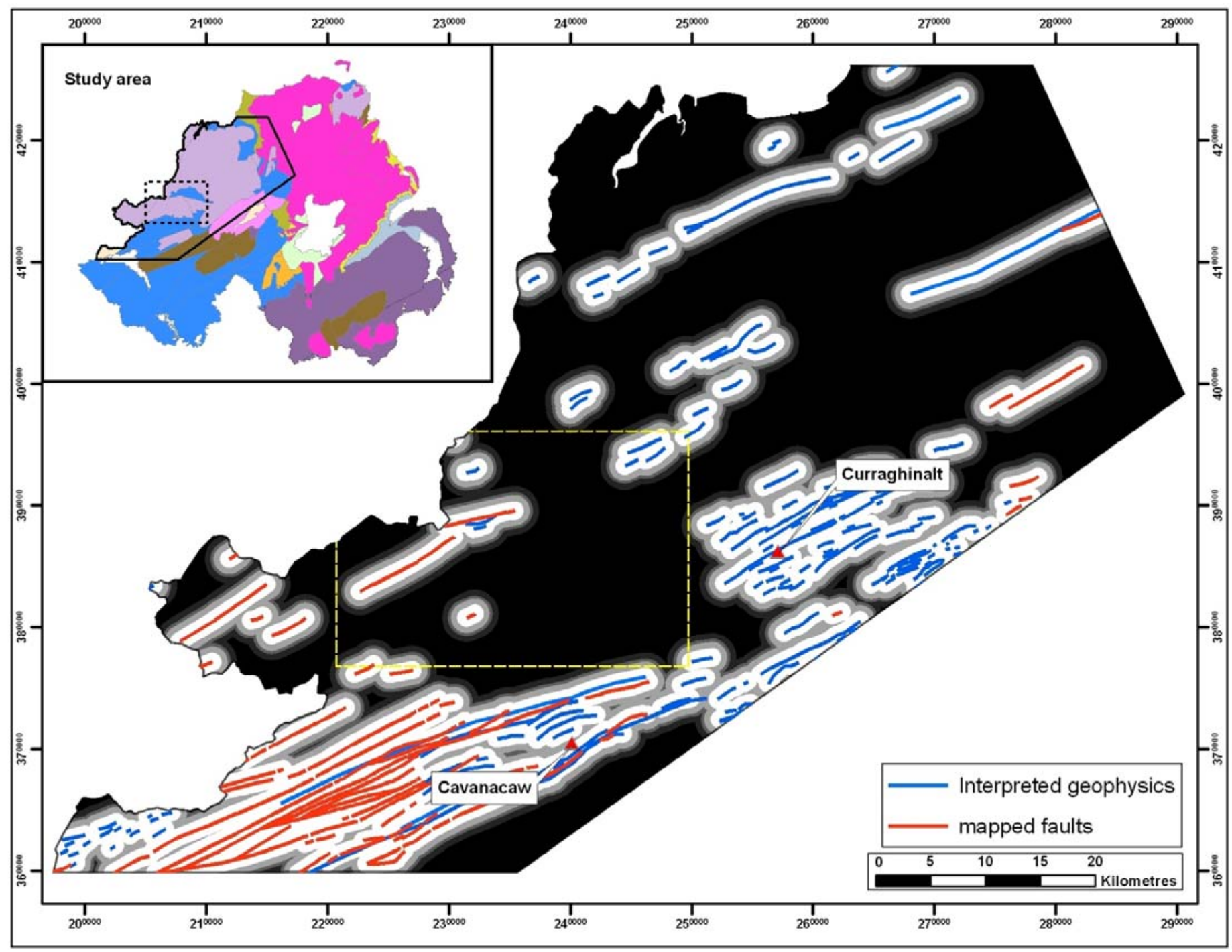

Figure 23 Buffered east-north-east-trending structures. 


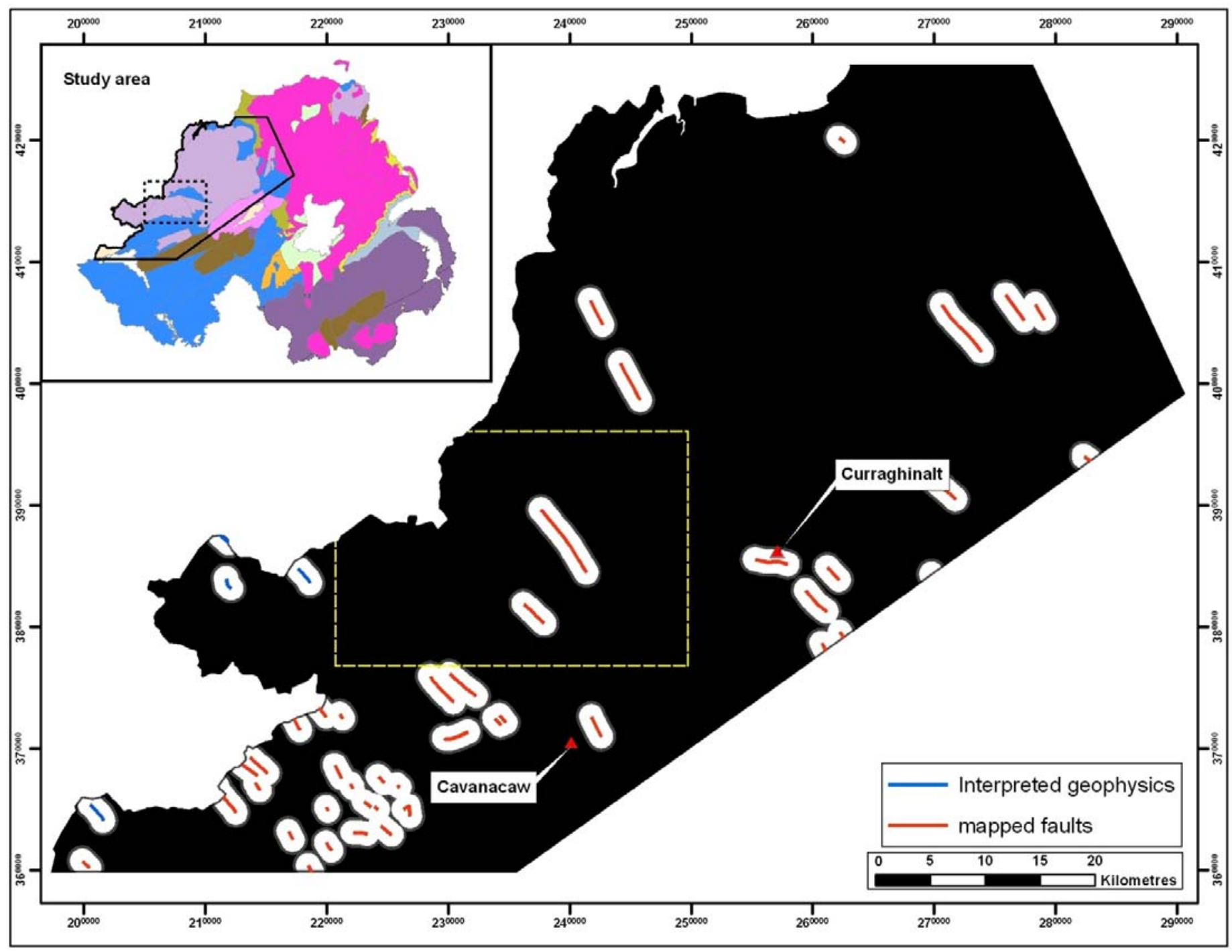

Figure 24 Buffered south-south-east-trending structures. 


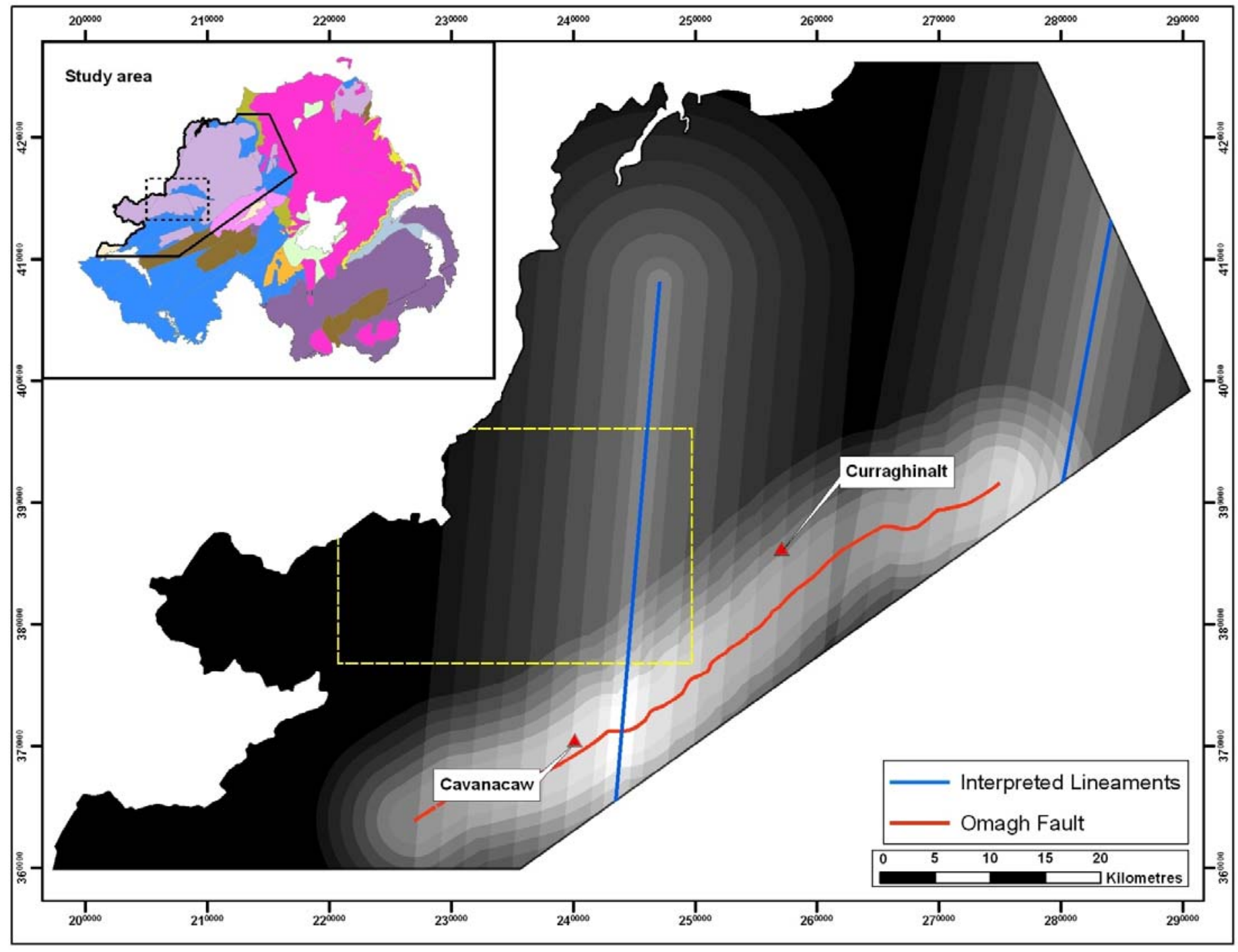

Figure 25 Buffered regional structures. 


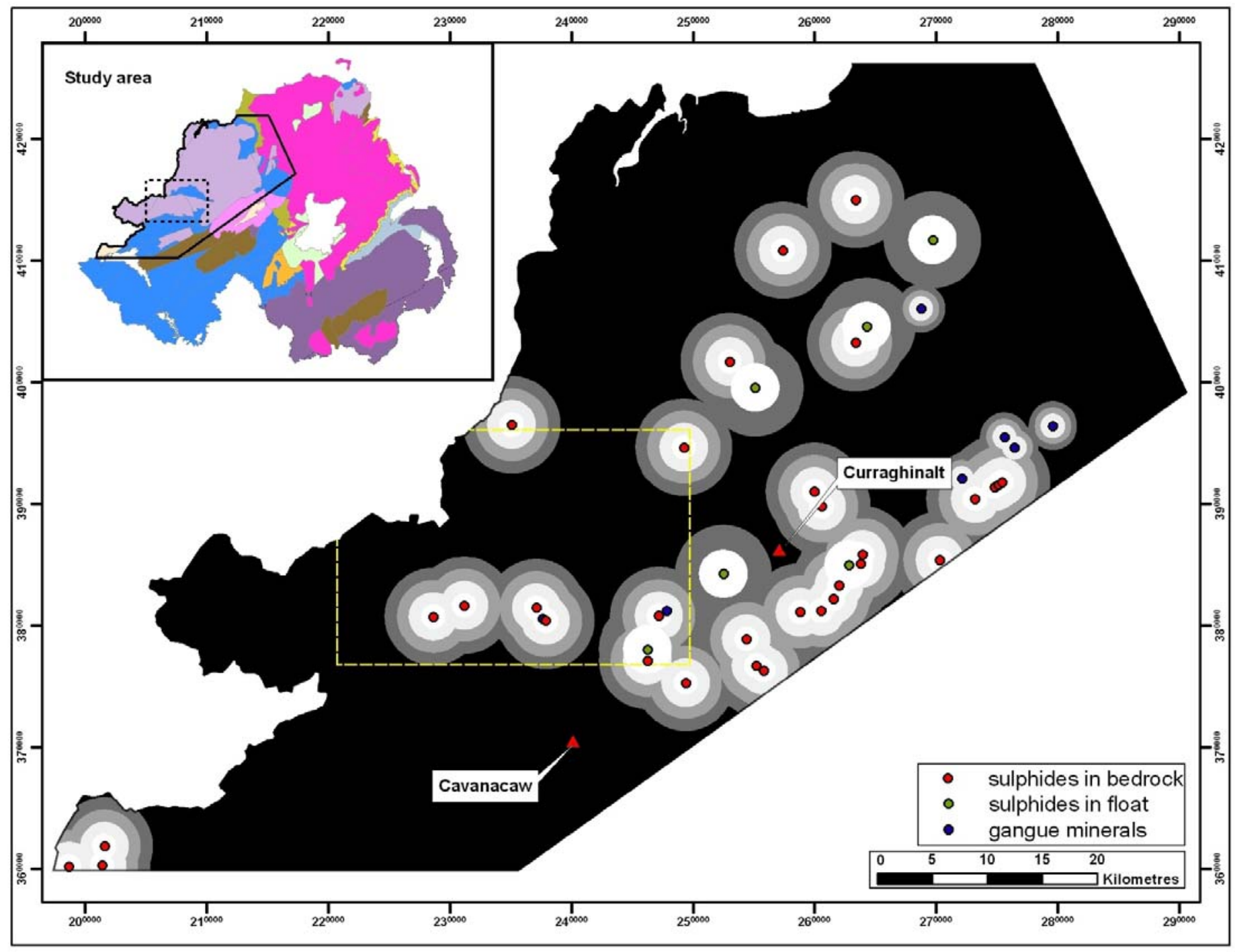

Figure 26 Buffered mineral occurrences. 


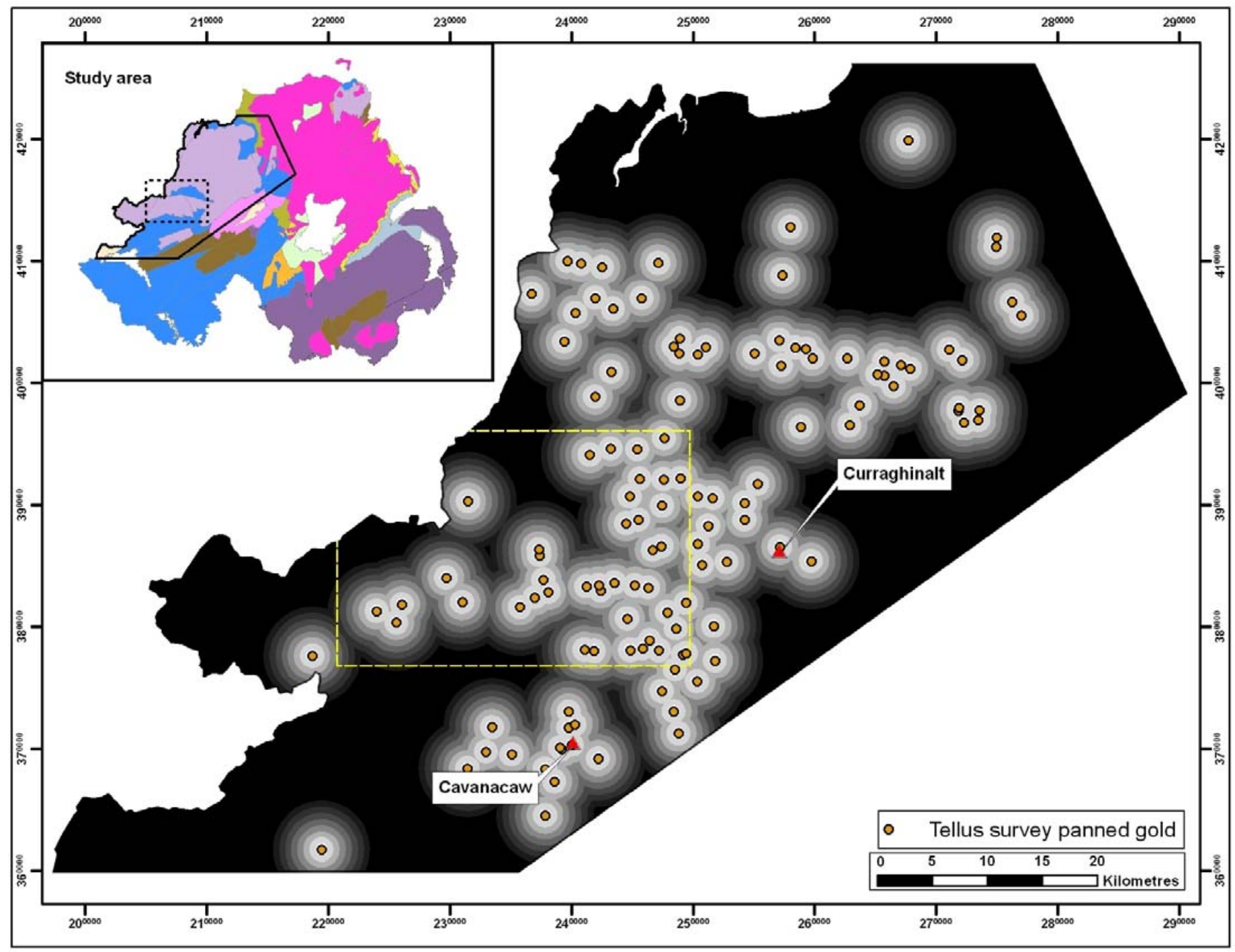

Figure 27 Buffered Tellus panned gold occurrences. 


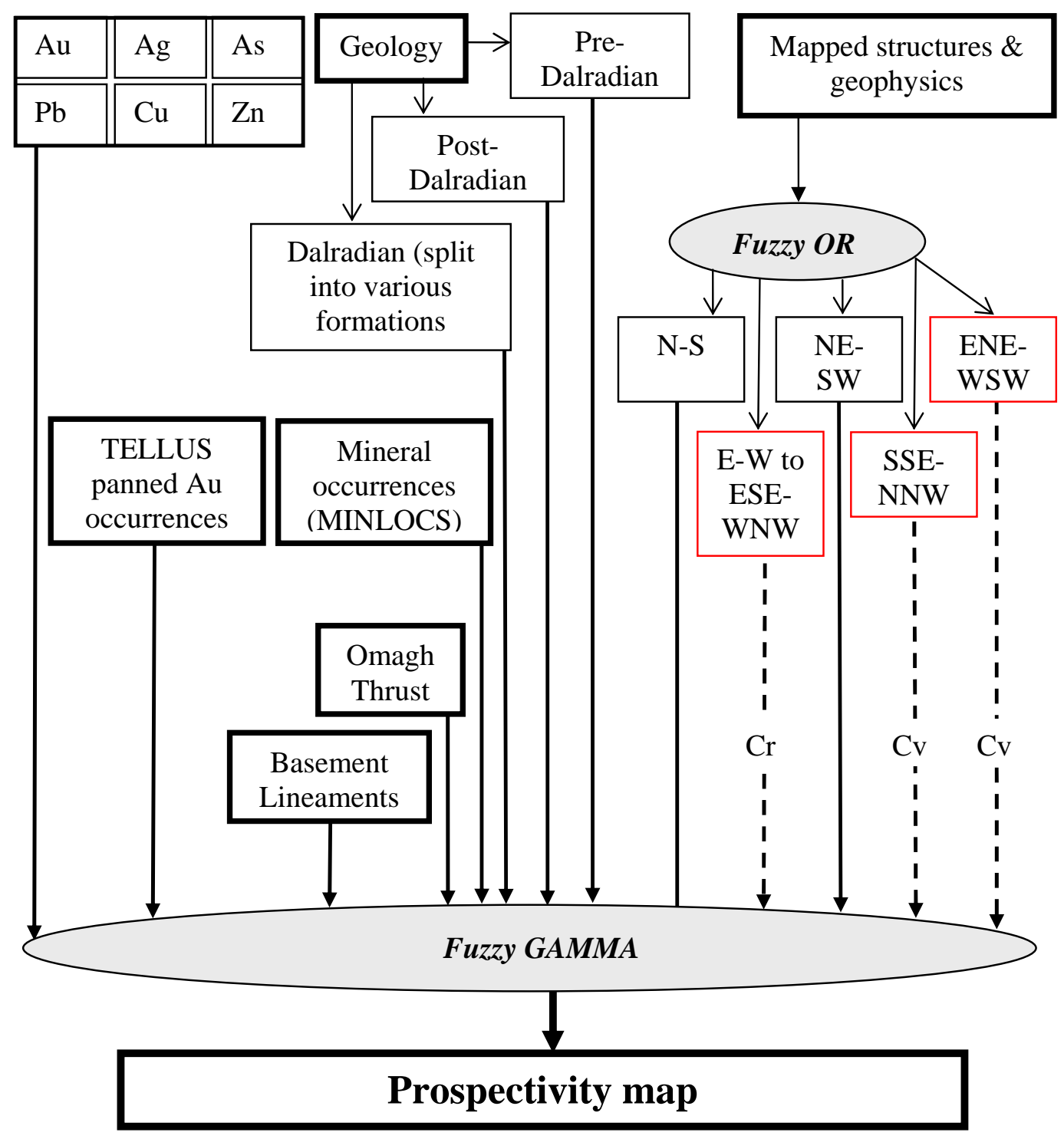

Figure 28 Schematic Fuzzy Logic model used for the Dalradian rocks of NW Northern Ireland (Cr - Curraghinalt model; Cv - Cavanacaw model), primary datasets are shown in boxes with thicker outlines and datasets only applicable to a single model are displayed in red.

\section{Results}

The result of the prospectivity analysis are displayed using a gradational colour scale from blue, representing relatively low prospectivity, through to red for areas of very high prospectivity. This scale is based on the grouping of Fuzzy Gamma values (Figure 28) into percentage ranges. For example, the top 5\% of Fuzzy Gamma values generated by each model are displayed in red on the maps.

\subsection{REGIONAL PROSPECTIVITY ANALYSIS}

The results of the regional prospectivity analysis based on the Curraghinalt and Cavanacaw models and incorporating undifferentiated Dalradian geology, are shown in Figures 28-29. The main criteria contributing to the prospectivity of the targets areas are detailed in Table 11. Validation of the results of the prospectivity analysis is an important part of the study. This was accomplished by comparing the locations of the most significant bedrock gold mineral 
occurrences, prospects and deposits with the distribution of prospectivity derived from the modelling.

Four broad groups of targets can be defined:

1. a western group comprising targets A-D, in the area of Newtownstewart-BaronscourtCastlederg;

2. a southern group extending over the Cavanacaw-Rylagh (E-K) area and eastwards;

3. an eastern group spanning the Golan Burn-Curraghinalt area $(\mathrm{O}-\mathrm{U})$; and

4. a northern group consisting of outlying, generally isolated targets (L, M, N, W).

The close correlation between the target areas generated by the two models is immediately apparent. The Curraghinalt model defines 21 targets, 15 of which are also clearly identified on the Cavanacaw prospectivity map. The Cavanacaw model identifies only one target (W) which is not produced using the Curraghinalt model.

\subsubsection{Western group}

This group of four targets, displaying relatively low prospectivity, is located to the west of the main prospective area associated with the Lack-Curraghinalt zone. The southern three targets (B-D) are identified in both models. They lie within an east-west-trending package of Dalradian rocks (Claudy, Dungiven, Newtownstewart Formations), containing numerous metabasite intrusions and bounded to the north and south by Carboniferous basins. Targets B-D are associated with north-south-trending structures and C and D are located along the faulted boundary of the Carboniferous Omagh-Kesh Basin. Target A, which is not apparent on the Cavanacaw map, is located on a major east-west-trending fault, bounding the southern side of the Newtownstewart Basin and extending into the Dalradian. It is important to note that this fault directly connects target A with the Golan Burn-Curraghinalt area to the east. We suggest this fault could be interpreted as the northern boundary of the western extension of the Curraghinalt lateral ramp, considered a key control on the location of the Curraghinalt deposit. It is possible that the southern boundary of the ramp structure is obscured by the Omagh-Kesh Basin. The Newtownstewart-Baronscourt-Castlederg area in which these targets fall is associated with broad and persistent geochemical anomalies for As, Zn, Ba and Ce in the Tellus soils data. Furthermore barite-base-metal mineralisation is reported from the Baronscourt area. 


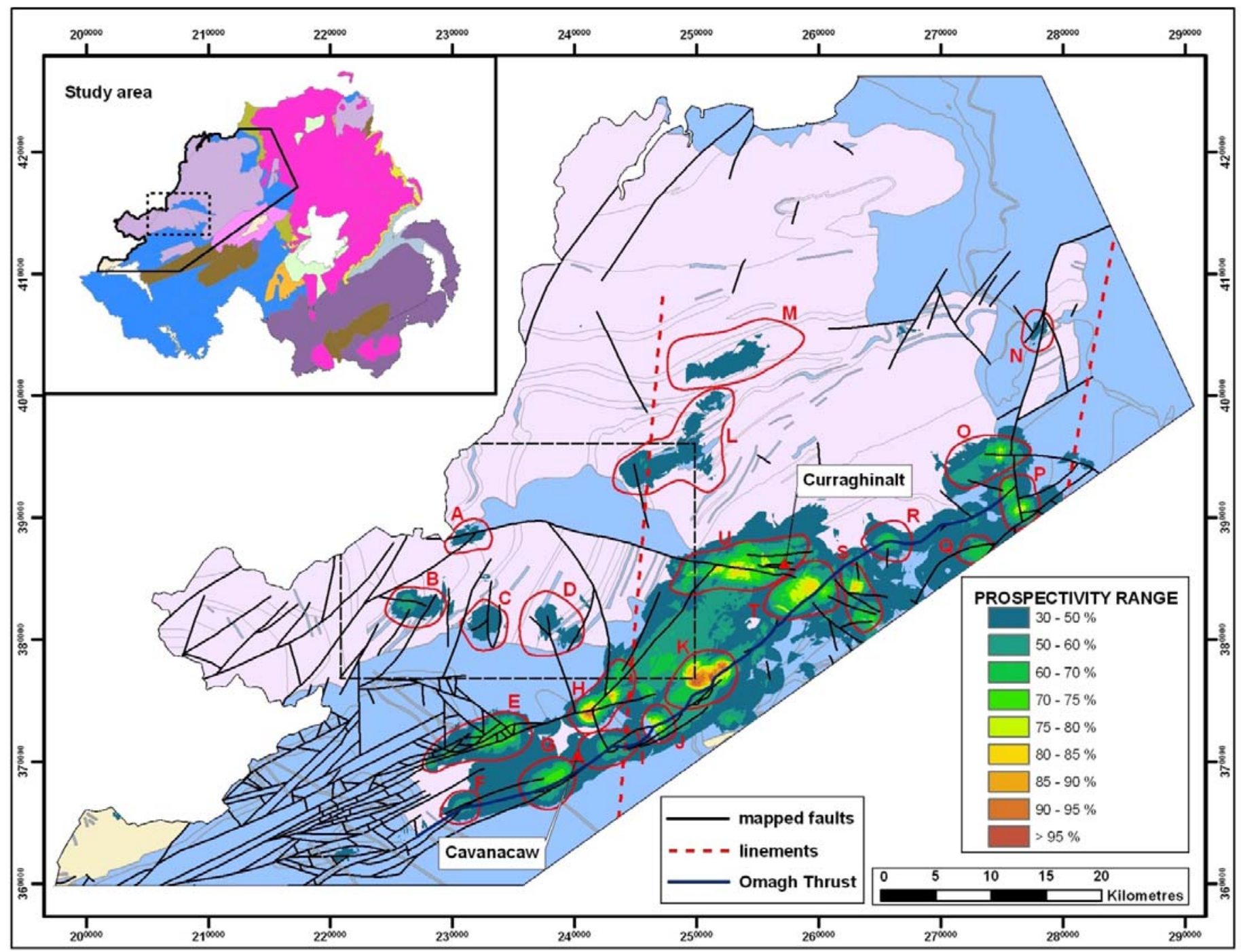

Figure 29 The distribution of prospectivity for orogenic gold mineralisation based on the Curraghinalt regional model (simplified geological theme). 


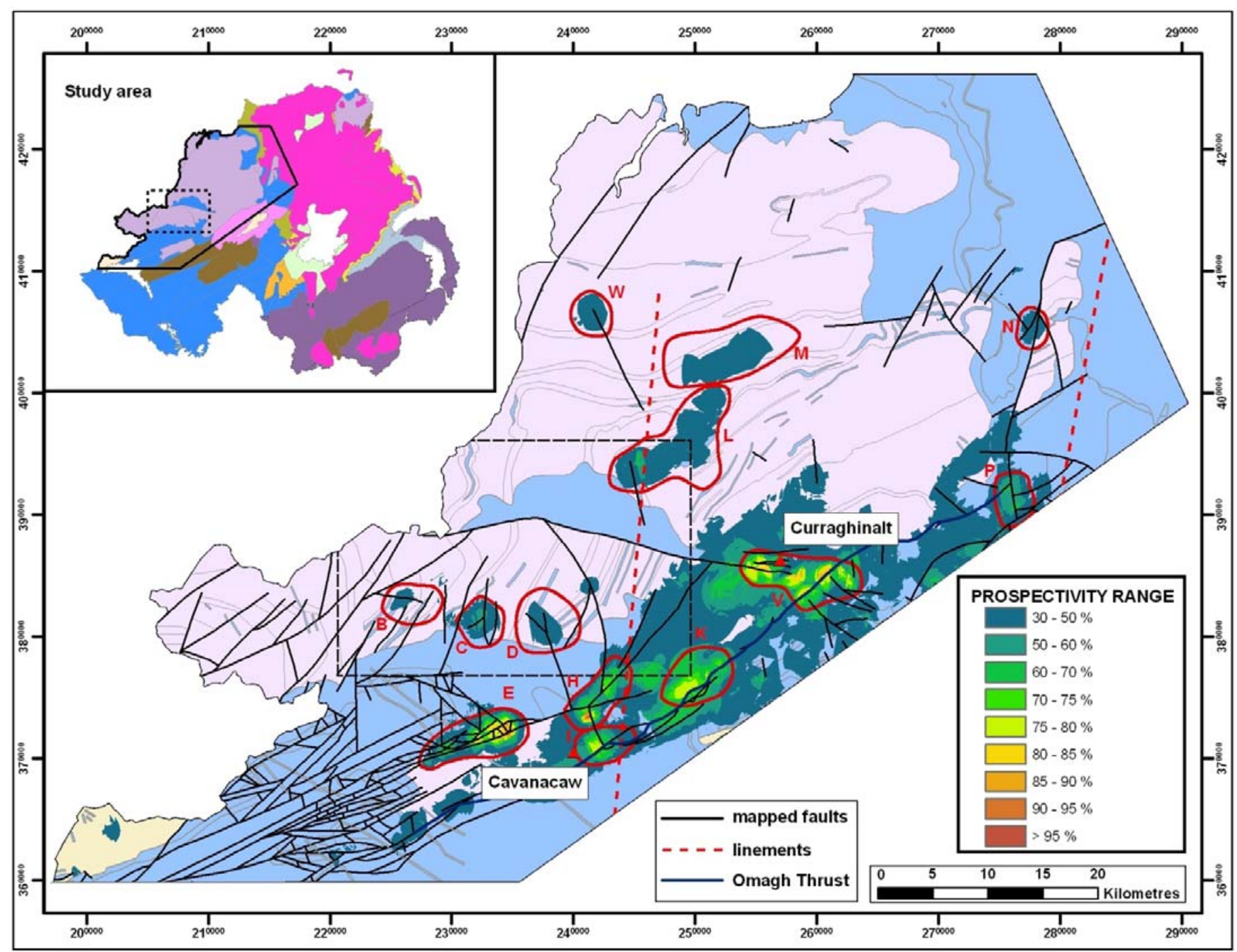

Figure 30 The distribution of prospectivity for orogenic gold mineralisation based on the Cavanacaw regional model (simplified geological theme). 


\begin{tabular}{|c|c|c|c|c|c|c|c|c|c|c|}
\hline Target & Prospectivity & $\begin{array}{l}\text { Area } \\
\left(\mathbf{k m}^{2}\right)\end{array}$ & Geology & $\begin{array}{l}\text { Incidence of } \\
\text { favourable } \\
\text { structural buffers }^{1}\end{array}$ & $\begin{array}{l}\text { Maximum } \\
\text { Au value in } \\
\text { stream- } \\
\text { sediments } \\
\text { (ppb) }\end{array}$ & $\begin{array}{l}\text { Elevated } \\
\text { pathfinders }\end{array}$ & $\begin{array}{l}\text { Incidence of Tellus } \\
\text { gold in panned } \\
\text { concentrates } \\
\text { occurrences }^{1}\end{array}$ & $\begin{array}{l}\text { Mineral } \\
\text { occurrences }\end{array}$ & 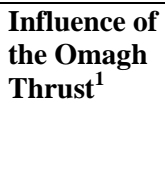 & $\begin{array}{l}\text { Influence of } \\
\text { basement } \\
\text { lineaments }\end{array}$ \\
\hline $\mathrm{A}(\mathrm{Cr})$ & low & 8 & $\begin{array}{l}\text { Claudy Fm, post- } \\
\text { Dalradian }\end{array}$ & 2 NE, 1 E-ESE (Cr) & 2 & $\mathrm{Zn}$ & 2 & 0 & None & Low \\
\hline B & low & 13 & Claudy Fm & $\begin{array}{l}4 \mathrm{NE}, 2 \mathrm{~N}, 1 \mathrm{E}-\mathrm{ESE} \\
(\mathrm{Cr}), 1 \mathrm{ENE}(\mathrm{Cv})\end{array}$ & 177 & $\mathrm{Zn}$ & 5 & 2 & None & Low \\
\hline $\mathrm{C}$ & low & 12 & $\begin{array}{l}\text { Dungiven Fm, post- } \\
\text { Dalradian }\end{array}$ & $\begin{array}{l}1 \mathrm{NE}, 2 \mathrm{~N}, 1 \mathrm{ENE} \\
(\mathrm{Cv})\end{array}$ & 0.5 & $\mathrm{Zn}$ & 3 & 3 & None & Low \\
\hline $\mathrm{D}$ & low & 22 & $\begin{array}{l}\text { Newtownstewart/D } \\
\text { ungiven Fm }\end{array}$ & $\begin{array}{l}1 \mathrm{NE}, 1 \mathrm{~N}, 1 \mathrm{SSE} \\
(\mathrm{Cv})\end{array}$ & 1 & $\mathrm{~Pb}, \mathrm{Zn}$ & $>6$ & 3 & None & Med. \\
\hline $\mathrm{E}$ & high & 27 & $\begin{array}{l}\text { Mullaghcarn Fm, } \\
\text { post-Dalradian }\end{array}$ & $\begin{array}{l}4 \text { NE, } 5 \text { N, } 5 \text { E-ESE } \\
\text { (Cr), } 3 \text { SSE (Cv), } \\
>9 \text { ENE (Cv) }\end{array}$ & 350 & & 4 & 0 & Mod. & Low \\
\hline $\mathrm{F}(\mathrm{Cr})$ & low & 7 & $\begin{array}{l}\text { Mullaghcarn Fm, } \\
\text { post-Dalradian }\end{array}$ & 2 NE, 1 E-ESE (Cr) & 22 & & 1 & 0 & High & Low \\
\hline $\mathrm{G}(\mathrm{Cr})$ & mod. & 15 & $\begin{array}{l}\text { Mullaghcarn Fm, } \\
\text { post-Dalradian }\end{array}$ & 3 NE, 2 E-ESE (Cr) & 223 & As, $\mathrm{Pb}$ & $>6$ & 0 & High & Med. \\
\hline $\mathrm{H}$ & v.high & 18 & $\begin{array}{l}\text { Mullaghcarn Fm, } \\
\text { post-Dalradian }\end{array}$ & $\begin{array}{l}1 \text { NE, } 1 \text { N, } 1 \text { E-ESE } \\
(\mathrm{Cr}), 1 \text { SSE (Cv), } \\
>7 \text { ENE }(\mathrm{Cv})\end{array}$ & 59 & & $>6$ & 1 & Mod. & High \\
\hline I & high & 12 & $\begin{array}{l}\text { Mullaghcarn Fm, } \\
\text { post-Dalradian }\end{array}$ & $\begin{array}{l}2 \text { NE, } 1 \text { E-ESE }(\mathrm{Cr}), \\
1 \quad \text { SSE (Cv), >6 } \\
\text { ENE (Cv) }\end{array}$ & 1094 & As, $\mathrm{Pb}$ & $>4$ & 0 & High & High \\
\hline $\mathrm{J}(\mathrm{Cr})$ & high & 7 & Post-Dalradian & 3 NE, 1 E-ESE (Cr), & NA & & 3 & 2 & High & High \\
\hline K & v.high & 21 & $\begin{array}{l}\text { Mullaghcarn Fm, } \\
\text { post-Dalradian }\end{array}$ & $\begin{array}{l}5 \text { NE, } 1 \text { E-ESE (Cr), } \\
3 \text { ENE (Cv) }\end{array}$ & 50 & As & $>6$ & 4 & High & Med. \\
\hline $\mathrm{L}$ & low & 48 & $\begin{array}{l}\text { Dungiven, Dart, } \\
\text { Newtownstewart } \\
\text { Fms }\end{array}$ & $\begin{array}{l}5 \mathrm{NE}, 1 \mathrm{~N}, 6 \mathrm{ENE} \\
(\mathrm{Cv})\end{array}$ & 10 & $\begin{array}{l}\text { As, } \mathrm{Cu}, \mathrm{Pb}, \\
\mathrm{Zn}\end{array}$ & $>6$ & 3 & None & High \\
\hline $\mathrm{M}$ & low & 43 & Claudy Fm & 3 NE, 4 ENE (Cv) & 18 & $\mathrm{As}, \mathrm{Pb}, \mathrm{Zn}$ & $>7$ & 2 & None & High \\
\hline $\mathrm{N}$ & low & 7 & $\begin{array}{l}\text { Dart Fm, post- } \\
\text { Dalradian }\end{array}$ & $\begin{array}{l}1 \mathrm{NE}, 1 \mathrm{~N}, 2 \mathrm{SSE} \\
(\mathrm{Cv})\end{array}$ & 2 & $\mathrm{Cu}$ & 2 & 0 & None & Med. \\
\hline
\end{tabular}




\begin{tabular}{|c|c|c|c|c|c|c|c|c|c|c|}
\hline $\mathrm{O}(\mathrm{Cr})$ & high & 20 & $\begin{array}{l}\text { Glenelly Fm, post- } \\
\text { Dalradian }\end{array}$ & $\begin{array}{l}2 \mathrm{NE}, 1 \mathrm{~N}, 3 \mathrm{E}-\mathrm{ESE} \\
(\mathrm{Cr})\end{array}$ & 2 & & 4 & 4 & Mod. & Med. \\
\hline $\mathrm{P}$ & mod. & 12 & Post-Dalradian & $\begin{array}{l}3 \mathrm{NE}, 1 \mathrm{~N}, 1 \mathrm{E}-\mathrm{ESE} \\
\text { (Cr), } 3 \text { ENE (Cv) }\end{array}$ & 3376 & & 0 & $>3$ & High & Med. \\
\hline $\mathrm{Q}(\mathrm{Cr})$ & mod. & 5 & Post-Dalradian & 3 NE, 1 E-ESE (Cr) & 0.5 & & 0 & 2 & Mod. & Med. \\
\hline $\mathrm{R}(\mathrm{Cr})$ & mod. & 10 & $\begin{array}{l}\text { Mullaghcarn Fm, } \\
\text { post-Dalradian }\end{array}$ & $\begin{array}{l}2 \mathrm{NE}, 1 \mathrm{~N}, 1 \mathrm{E}-\mathrm{ESE} \\
\text { (Cr) }\end{array}$ & 31 & & 0 & $>2$ & High & Low \\
\hline S (Cr) & high & 12 & Post-Dalradian & $\begin{array}{l}3 \mathrm{NE}, 2 \mathrm{~N}, 4 \text { E-ESE } \\
\text { (Cr) }\end{array}$ & 70 & & 1 & 5 & High & Low \\
\hline $\mathrm{T}(\mathrm{Cr})$ & high & 21 & $\begin{array}{l}\text { Mullaghcarn Fm, } \\
\text { post-Dalradian }\end{array}$ & $\begin{array}{l}5 \mathrm{NE}, 1 \mathrm{~N}, 3 \mathrm{E}-\mathrm{ESE} \\
(\mathrm{Cr})\end{array}$ & 842 & As & 2 & $>6$ & High & Low \\
\hline $\mathrm{U}(\mathrm{Cr})$ & high & 36 & $\begin{array}{l}\text { Mullaghcarn, } \\
\text { Glengawna, } \\
\text { Glenelly Fms, post- } \\
\text { Dalradian }\end{array}$ & $\begin{array}{l}10 \mathrm{NE}, 1 \mathrm{~N}, 4 \mathrm{E}- \\
\text { ESE (Cr) }\end{array}$ & 3485 & & $>5$ & 3 & Mod. & Med. \\
\hline $\mathrm{V}(\mathrm{Cv})$ & v.high & 31 & $\begin{array}{l}\text { Mullaghcarn, } \\
\text { Glengawna Fms, } \\
\text { post-Dalradian }\end{array}$ & $\begin{array}{l}10 \mathrm{NE}, 3 \mathrm{SSE}(\mathrm{Cv}) \text {, } \\
>6 \mathrm{ENE}(\mathrm{Cv})\end{array}$ & 3485 & As & 4 & $>6$ & High & Med. \\
\hline $\mathrm{W}(\mathrm{Cv})$ & low & 10 & Claudy Fm & $\begin{array}{l}2 \mathrm{NE}, 1 \mathrm{~N}, 1 \mathrm{SSE} \\
(\mathrm{Cv}), 2 \mathrm{ENE}(\mathrm{Cv})\end{array}$ & 36 & & $>3$ & 0 & None & Med. \\
\hline
\end{tabular}

Table 13 Summary of criteria contributing to the prospectivity of the regional target areas (Cr - Curraghinalt specific; Cv - Cavanacaw specific)

${ }^{1}$ Columns 5, 8, 10 and 11 refer to exploration criteria falling within the polyon and/or the influence of exploration criteria on the polygon as a result of buffering. 


\subsubsection{Southern group}

A group of seven targets (E-K) of generally moderate to high prospectivity fall within an eastwest trending area corresponding with the orientation of the Lack-Curraghinalt zone. Five of the targets (F, G, I, J, K), occur along strike from Cavanacaw, extending across the Omagh Thrust. Two additional targets $(\mathrm{E}, \mathrm{H})$ are located on the northern side of the Lack Inlier, extending into the Carboniferous Omagh-Kesh Basin. The targets are underlain by a combination of Dalradian and post-Dalradian rocks. The Mullaghcarn Formation is associated with all of the targets with the exception of $\mathrm{J}$ which is underlain by Carboniferous and Devonian rocks and the Tyrone Volcanic Group. Target $\mathrm{H}$ is located midway between the Cavanacaw deposit and the Rylagh gold occurrence, underlain mostly by Carboniferous sedimentary rocks with subordinate Mullaghcarn Formation. It is significant to note that target D in the western group is directly linked to target $\mathrm{H}$ and to the Lack Inlier by a north-north-west-trending fault.

Target K represents the area of highest prospectivity identified by the modelling and does not coincide with either the Curraghinalt or Cavanacaw deposits. Its geology is dominated by the Mullaghcarn Formation but the prospective area extends south over the Ordovician Tyrone Volcanic Group, straddling the Omagh Thrust. The volcanic-hosted Au mineralisation at Crosh is located within target $\mathrm{K}$. The fact that $\mathrm{K}$ is the modelled as the most prospective zone is significant as it lies along strike from the Cavanacaw deposit and is also located at the eastern end of a west-north-west trending linear series of targets (B, C, D) passing through the gold occurrence at Rylagh. These features provide further evidence that this zone marks the boundary of a major, obscured west-north-west-trending structure, parallel to that observed along the southern side of Newtownstewart Basin. It is possible that the Crosh occurrence, which is close to the Omagh Thrust and the Mullaghcarn Formation, may be related to a Dalradian structure and the trend discussed above. Targets H, I, J and $\mathrm{K}$ cluster around the inferred Omagh Lineament, the northern projection of which coincides with targets $\mathrm{L}$ and $\mathrm{M}$.

As would be expected the Cavanacaw prospectivity map returns higher levels of prospectivity in the vicinity of the Cavanacaw deposit. The deposit sits within an elongated zone of moderate to high prospectivity, offset to the west by around $1.5 \mathrm{~km}$ from the point of maximum prospectivity. In contrast the Curraghinalt map defines two separate targets $(G, I)$ in the area of the elongated zone discussed above. On the Curraghinalt map Cavanacaw sits between the two targets in an area of very low prospectivity. This lack of correlation between the Cavanacaw deposit and the zone of high prospectivity may be explained in a number of ways:

1. the factors controlling the location of mineralisation are not fully understood;

2. it has not been possible to accurately translate the exploration criteria into the prospectivity model;

3. the modelling has incorporated deposit-scale characteristics, whilst the prospectivity analysis is based upon regional-scale datasets, resulting in an issue of data suitability.

We conclude that the southern group of targets is highly prospective. This is supported by the presence of an operating gold mine and a second minor deposit (Rylagh). The prospectivity of the Omagh Thrust is confirmed and the parallel fault zone bounding the northern side of the Lack Inlier also appears highly prospective. A further consideration relates to the mapping of the Dalradian in the Lack-Curraghinalt zone. In targets $\mathrm{E}$ and $\mathrm{H}$ the Dalradian is mapped as the Mullaghcarn Formation. The Glengawana Formation, possibly obscured by the Carboniferous, is not mapped in the vicinity of the Lack Inlier. However, a postulated extension of the Glengawana Formation based on its relationship to the Mullaghcarn Formation, in the Curraghinalt area, would coincide with both targets $\mathrm{E}$ and $\mathrm{H}$. As discussed previously proximity to the Glengawana Formation is suggested to play a role in the location of mineralisation. 


\subsubsection{Eastern group}

Analysis based on the Curraghinalt model has identified seven targets $(\mathrm{O}-\mathrm{U})$ of moderate to high prospectivity in the vicinity of Curraghinalt and extending further east. Three separate targets (U, T, S) extending from the eastern limit of the Newtownstewart Basin, through the Curraghinalt zone and south of the Omagh Thrust can be differentiated based on the Curraghinalt prospectivity map. Targets $\mathrm{U}, \mathrm{T}$ and $\mathrm{S}$ are located on the major fault bounding the Newtownstewart Basin, or its projected trend eastwards. In contrast, a single target (V) is delineated by the Cavanacaw model. Curraghinalt and Golan Burn both occur within target U, a zone of high prospectivity. Neither of these deposits is coincident with the maximum prospectivity within target $U$. The geology of target $U$ is dominated by Dalradian rocks of the Mullaghcarn, Glengawna and Glenelly Formations. The eastern end of the Carboniferous Newtownstewart Basin extends into target $\mathrm{U}$.

Target $\mathrm{T}$ straddles the Omagh Thrust and is underlain mostly by the Dalradian Mullaghcarn Formation. It extends onto the outcrop of the Tyrone Volcanic Group and parts of an Ordovician tonalite intrusion. Target $\mathrm{S}$ is underlain by the tonalite intrusion and Tyrone Volcanic Group rocks. Moving eastwards the targets are generally of moderate prospectivity, with target $\mathrm{R}$ straddling a distinct jog in the Omagh Thrust. Target $\mathrm{O}$ is dominated by the Dalradian Glenelly Formation, with subordinate Carboniferous sedimentary rocks, and is influenced by both the Omagh Thrust and Draperstown Lineament. Target $\mathrm{P}$ is underlain by the Tyrone Volcanic Group, Carboniferous sedimentary rocks and a small wedge of the Dalradian Glenelly Formation. Target Q falls entirely within the Tyrone Igneous Complex and is notable for high levels of As and Ag in stream-sediments.

The model has successfully located the known deposits of Curraghinalt and Golan Burn. However, it has also substantially extended the prospective mineralised corridor from the Newtownstewart basin in the west, across the Omagh Thrust into the Tyrone Volcanic Group.

\subsubsection{Northern group}

This group consists of four isolated targets of relatively low prospectivity, three of which (L, M, $\mathrm{N}$ ) are clearly identified by both models. $\mathrm{L}$ and $\mathrm{M}$ are located directly north of Golan Burn and Curraghinalt, along the trend of the inferred Omagh Lineament. An additional target (W) is only observed on the Cavanacaw prospectivity map. With the exception of $\mathrm{N}$, these targets are all underlain by Dalradian rocks of the Dart, Dungiven, Newtownstewart and Claudy Formations. Target L coincides with the change in strike of the Dalradian, close to the hinge of the Sperrin Fold, and the inferred trace of the Omagh Lineament. Target $\mathrm{N}$ includes sections of the Dart Formation, Carboniferous sedimentary rocks and Palaeogene basalts. Elevated base metal values in this area may be related to the Tertiary basalts.

This group is remote from the main area of prospectivity associated with the Lack-Curraghinalt zone and all targets occur in close proximity to inferred, north-south basement lineaments. L and $\mathrm{M}$ are also proximal to the hinge zone of the Sperrin anticline.

\subsection{DETAILED PROSPECTIVITY ANALYSIS OF THE NEWTOWNSTEWART SHEET}

Detailed prospectivity analysis focusing on a part of the regional project area was undertaken to study the potential benefits of incorporating more detailed structural data into the analysis. The models developed for Curraghinalt and Cavanacaw were used in this detailed analysis which focussed on the Newtownstewart 1:50 000 scale geological sheet (Figures 2 and 4). This area was selected because the regional results identify a number of targets beyond the LackCurraghinalt zone. The Newtownstewart sheet is also one of the first map sheets to be revised on the basis of the Tellus data. The datasets used in the detailed analysis were the same as in the regional model, with the exception of additional structural controls derived from the 1: 50000 
scale geological map and from a more detailed interpretation of the Tellus geophysical data (Figure 12). A sub-set of the Tellus stream-sediment geochemical data relating to Newtownstewart sheet was selected for the detailed analysis. This dataset was re-gridded as the range of data values for the elements considered differs from those in the regional dataset.

The results of the detailed prospectivity analysis based on the Curraghinalt and Cavanacaw models and incorporating undifferentiated Dalradian geology are shown in Figures 30-31. For the Curraghinalt model the analysis has identified extensive (in excess of $10 \mathrm{~km}$ in length), more or less continuous areas of relatively low to moderate prospectivity. In contrast, prospectivity analysis based on the Cavanacaw model has produced less extensive, more isolated zones of low to moderate prospectivity. Both models identify area of very high prospectivity in the south-east corner of the sheet. Both also identify a zone of low prospectivity in the north-east corner of the sheet, largely beyond the limits of the Newtownstewart Basin. This zone extends slightly further west based on the Curraghinalt model. Prospective zones extend onto the Carboniferous outcrop for both models.

\subsubsection{Comparison of the results of the regional and detailed analyses}

A direct comparison has been made between the location and extent of targets resulting from the different scales of prospectivity analysis:

i. The zones of prospectivity resulting from the detailed analysis are considerably more extensive than those defined by the regional analysis (Figures 32-33). This has resulted in some isolated anomalies on the regional maps merging with adjacent anomalies through zones of low prospectivity. This is due to the prospectivity contribution from the greater amount of structural data in areas previously devoid of information in the regional analysis. For example, based on the Curraghinalt model, target A on the regional map has become incorporated on the detailed map into an extensive north-south-trending zone of prospectivity which includes targets B and C.

ii. A zone of moderate to high prospectivity has emerged on the Curraghinalt detailed map located between regional targets B and C.

iii. Both the Curraghinalt and Cavanacaw detailed models result in the same zone of low prospectivity in the north-east corner corresponding to target $L$ from the regional analysis. In both cases this area is more extensive than that derived from the regional analysis.

iv. A zone of high to very high prospectivity is observed in the extreme south-east corner of the Newtownstewart sheet based on the regional Curraghinalt analysis. This is also observed on the detailed Curraghinalt map. In addition further zones of high to very high prospectivity are identified to the west, completely absent from the regional results. The detailed Cavanacaw model also displays coincident zones of high to very high prospectivity in the south-east corner of the area, which are not observed on the regional Cavanacaw map. Significantly one of these new zones of high prospectivity coincides with the minor deposits at Rylagh and Erganagh Burn.

Both the Curraghinalt and Cavanacaw detailed models have identified areas of prospectivity not evident on the regional maps such as the areas of low prospectivity to the north-west corner of the Newtownstewart Basin and to its immediate south.

In summary although a greater part of the Newtownstewart sheet appears to be prospective based on the Curraghinalt model, on closer inspection the total area covered by zones of moderate to high prospectivity is comparable. The addition of more detailed structural data has retained both the location and intensity of the regional targets. However, areas of low prospectivity have increased in extent and in some instances regional targets have merged. This is attributed to the same Fuzzy Membership values being applied to both the local and regional structures (with the exception of the Omagh Thrust and Omagh Lineament) as explained in Section 6. 


\subsection{THE EFFECT OF ASSIGNING INTRA-DALRADIAN RANKINGS}

Applying different fuzzy logic values to individual Dalradian formations whilst maintaining the relative importance of geology and other evidential themes results in very subtle changes to the final prospectivity maps, for the Curraghinalt and Cavancaw models at both a regional and detailed scale (Figure 35-41). Subtle changes are generally observed in the lower part of the prospectivity range, with little influence in the higher prospectivity zones. In comparison with the initial modelling in which all Dalradian formations were allocated the same level of prospectivity and V1 (in which a narrow range of fuzzy membership values were allocated to Dalradian formations), the expanded range used in V2 for the detailed analysis has influenced the prospectivity in the south-east corner of the Newtownstewart sheet over the Glengawna and the Mullaghcarn Formations. The zone of moderate prospectivity in the extreme south-east corner of the map sheet has extended northwards into the vicinity of the north-east-trending mapped thrusts (Figures 40-41). Assigning variable weightings to different Dalradian formations has a limited influence on the final prospectivity map as geology is only one of fifteen evidential themes being combined to form the resultant prospectivity map. 


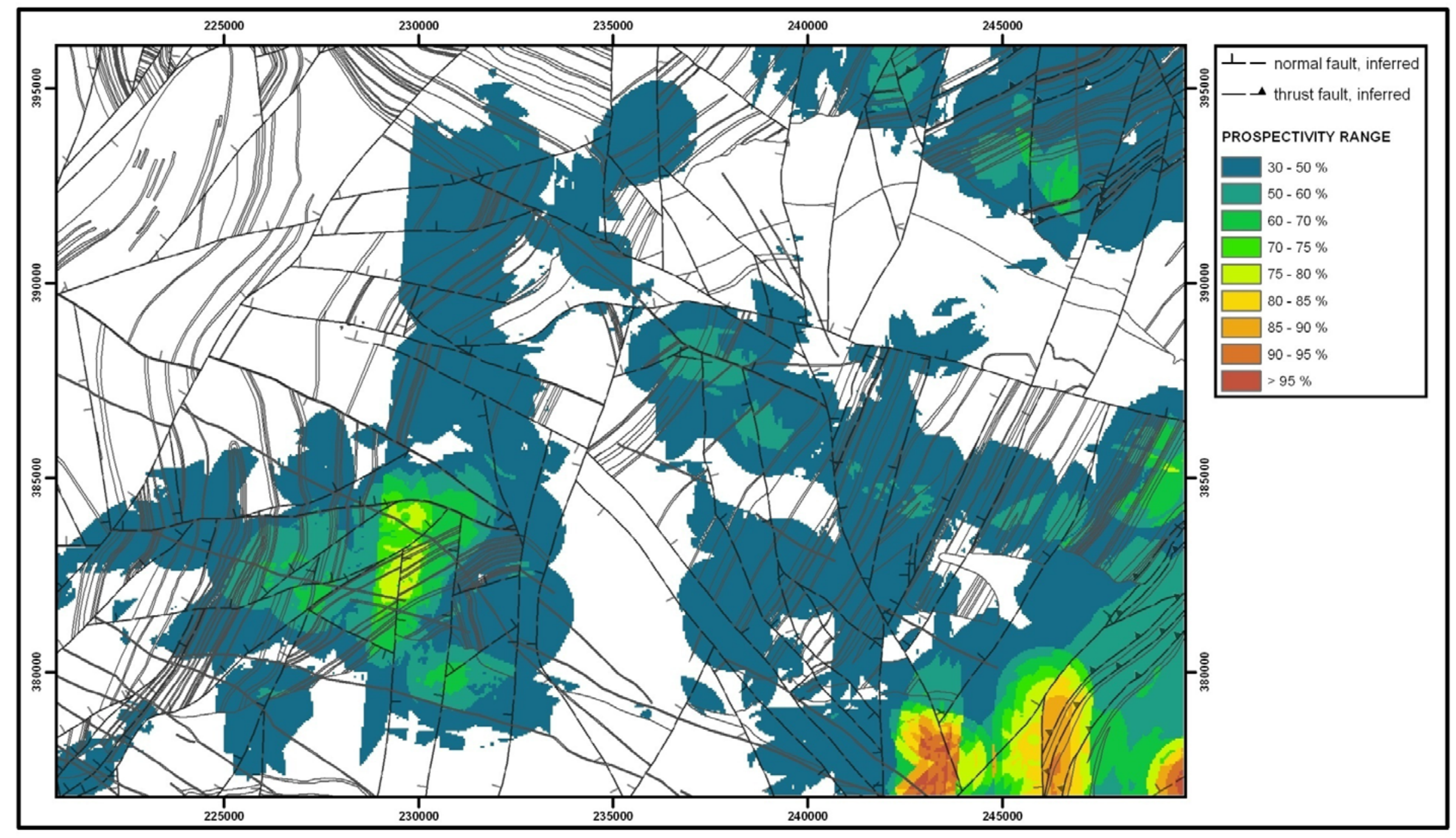

Figure 31 Curraghinalt model detailed prospectivity analysis results (simplified geological theme). 


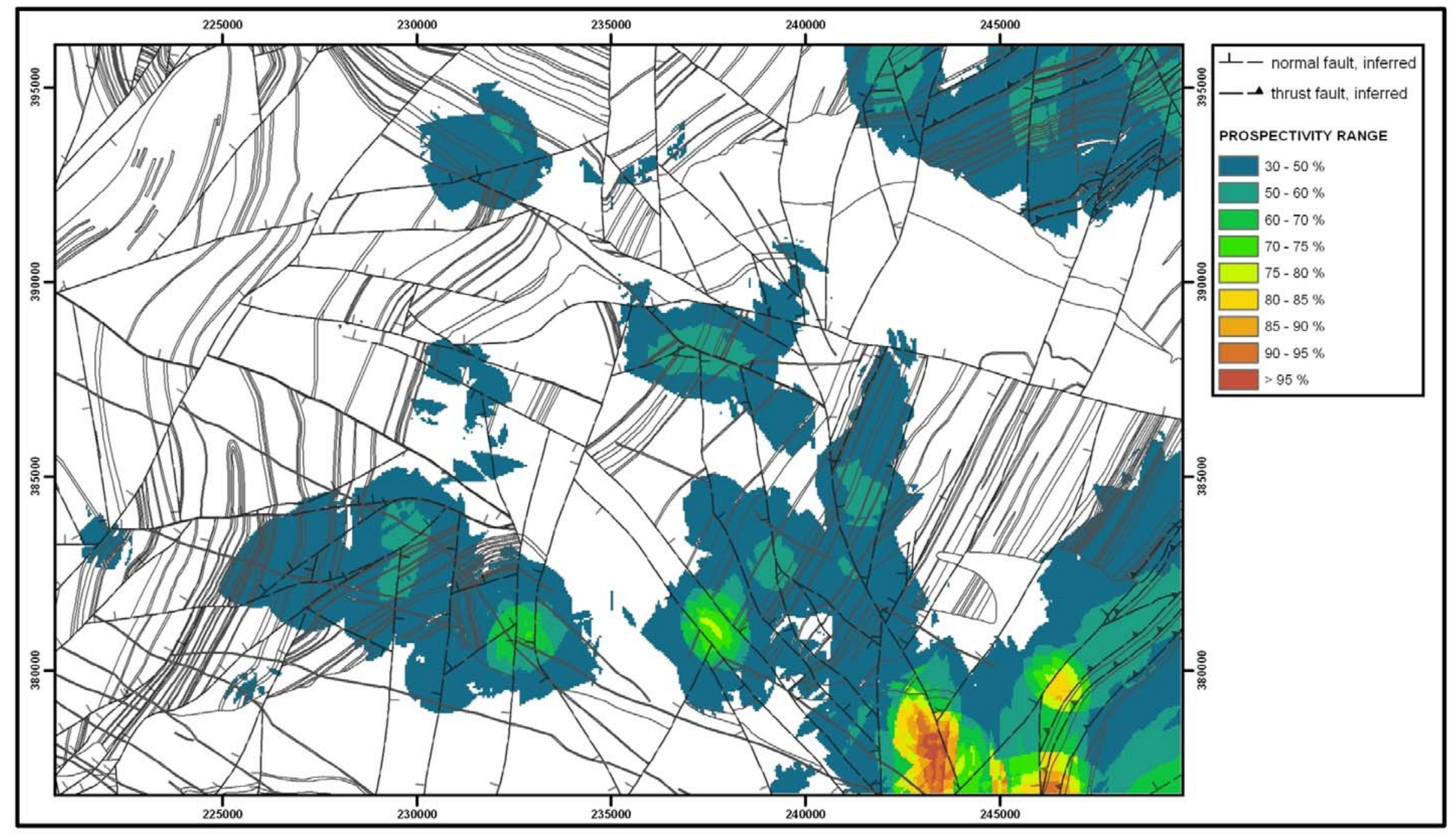

Figure 32 Cavanacaw model detailed prospectivity analysis results (simplified geological theme). 


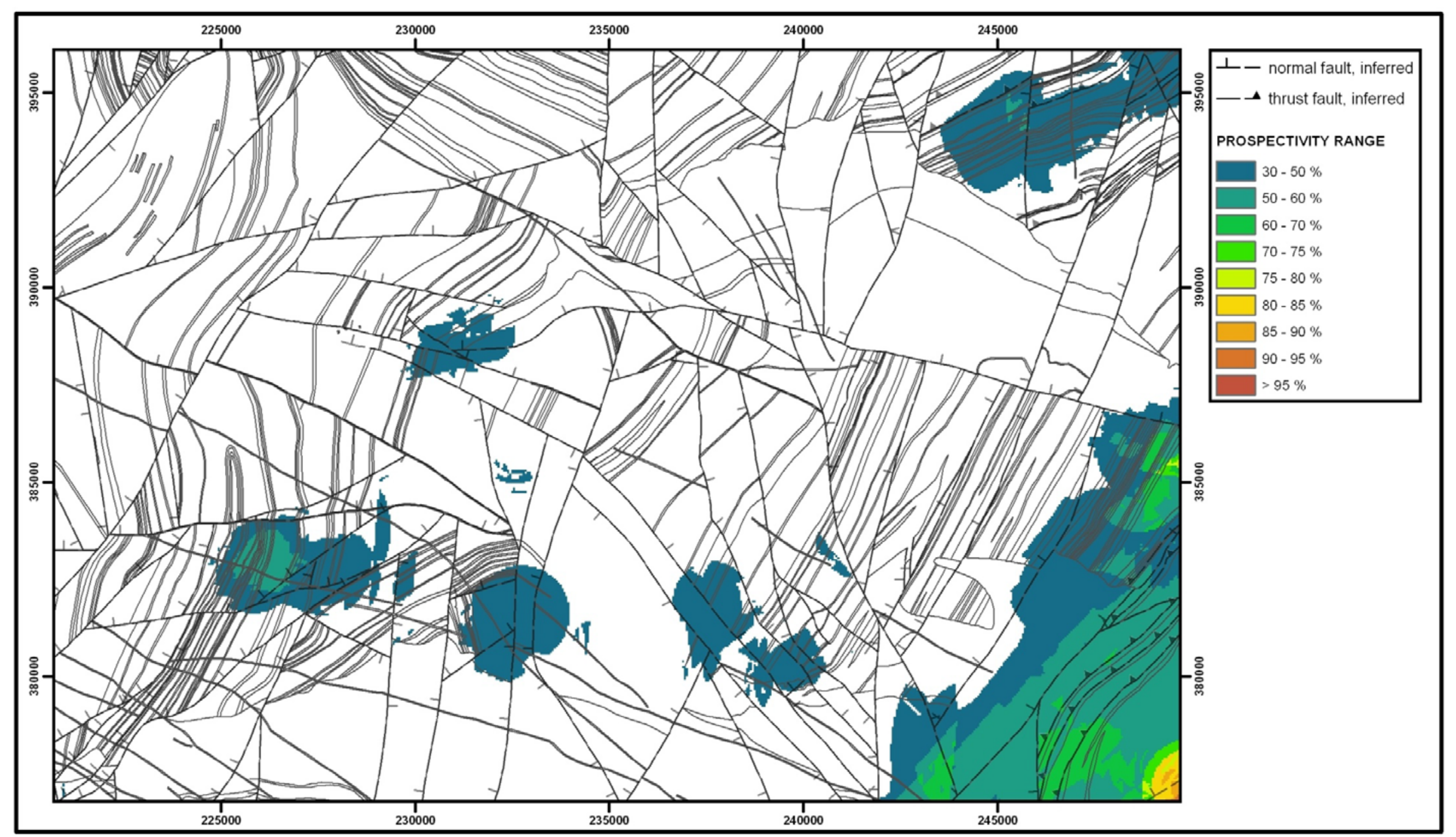

Figure 33 Curraghinalt model regional prospectivity analysis results displayed over Newtownstewart 1:50 000 scale geology (simplified geological theme). 


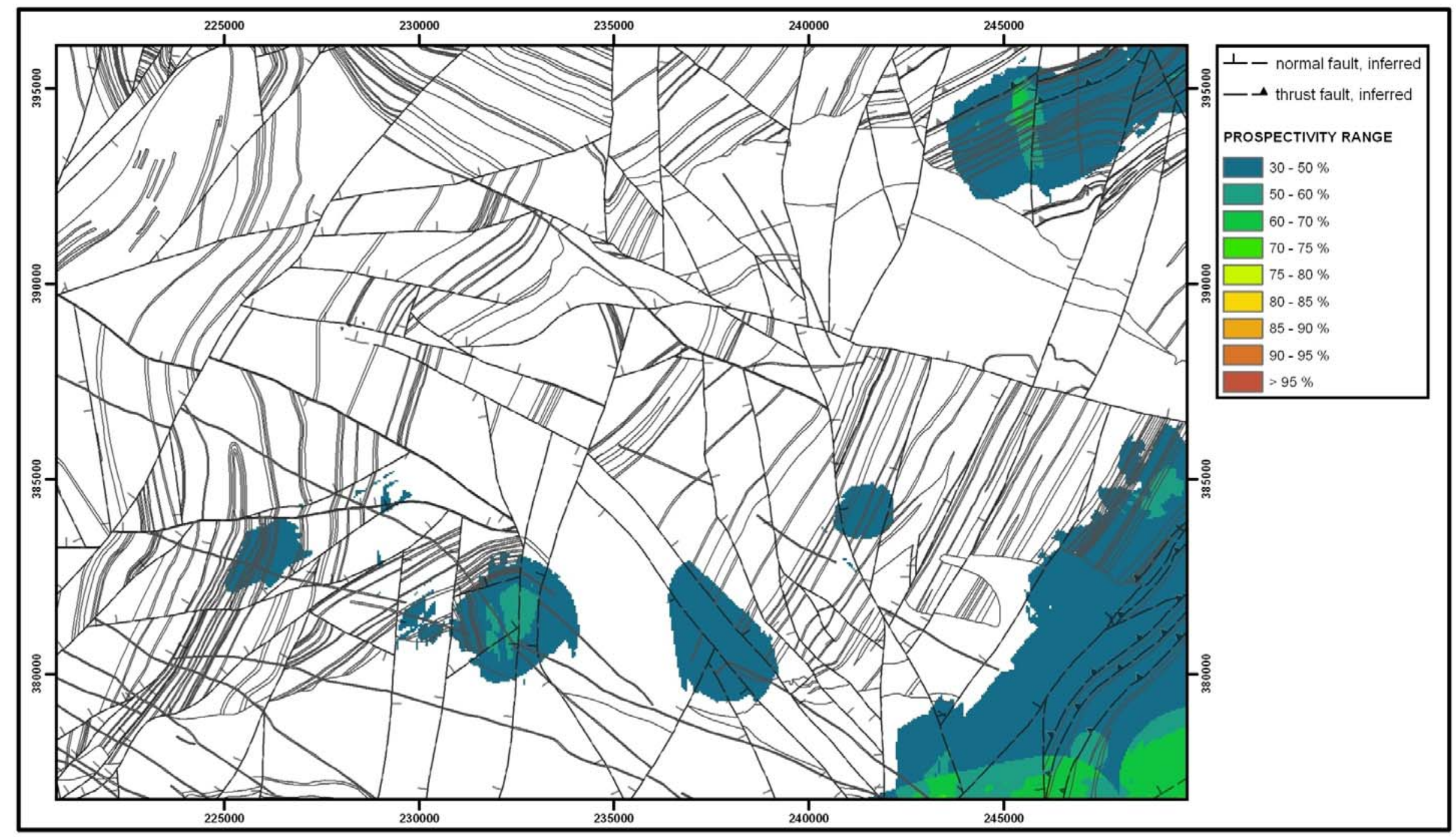

Figure 34 Cavanacaw model regional prospectivity analysis results displayed over Newtownstewart 1:50 000 scale geology (simplified geological theme). 


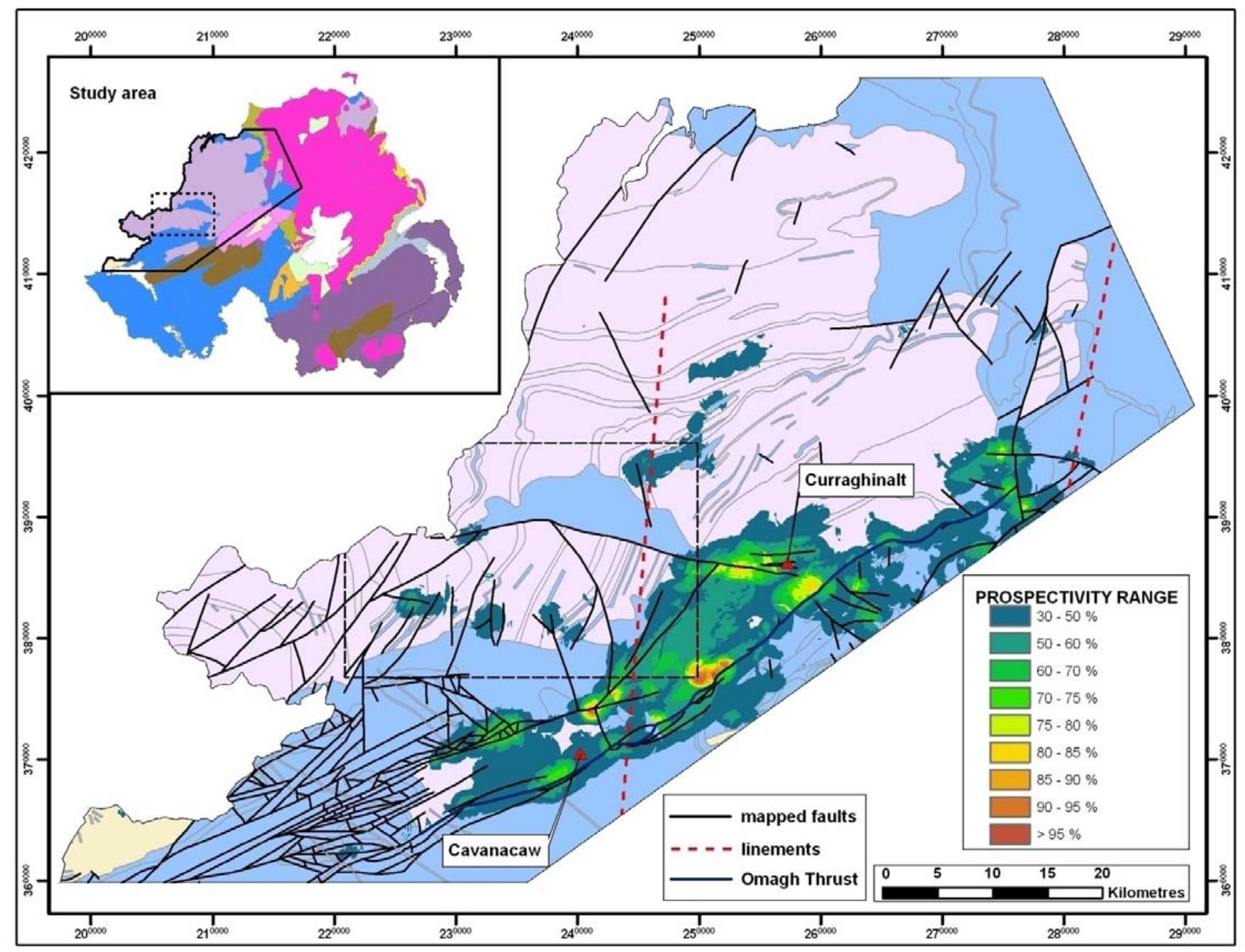

Figure 35 Curraghinalt model regional prospectivity analysis results incorporating V1 geology theme. 


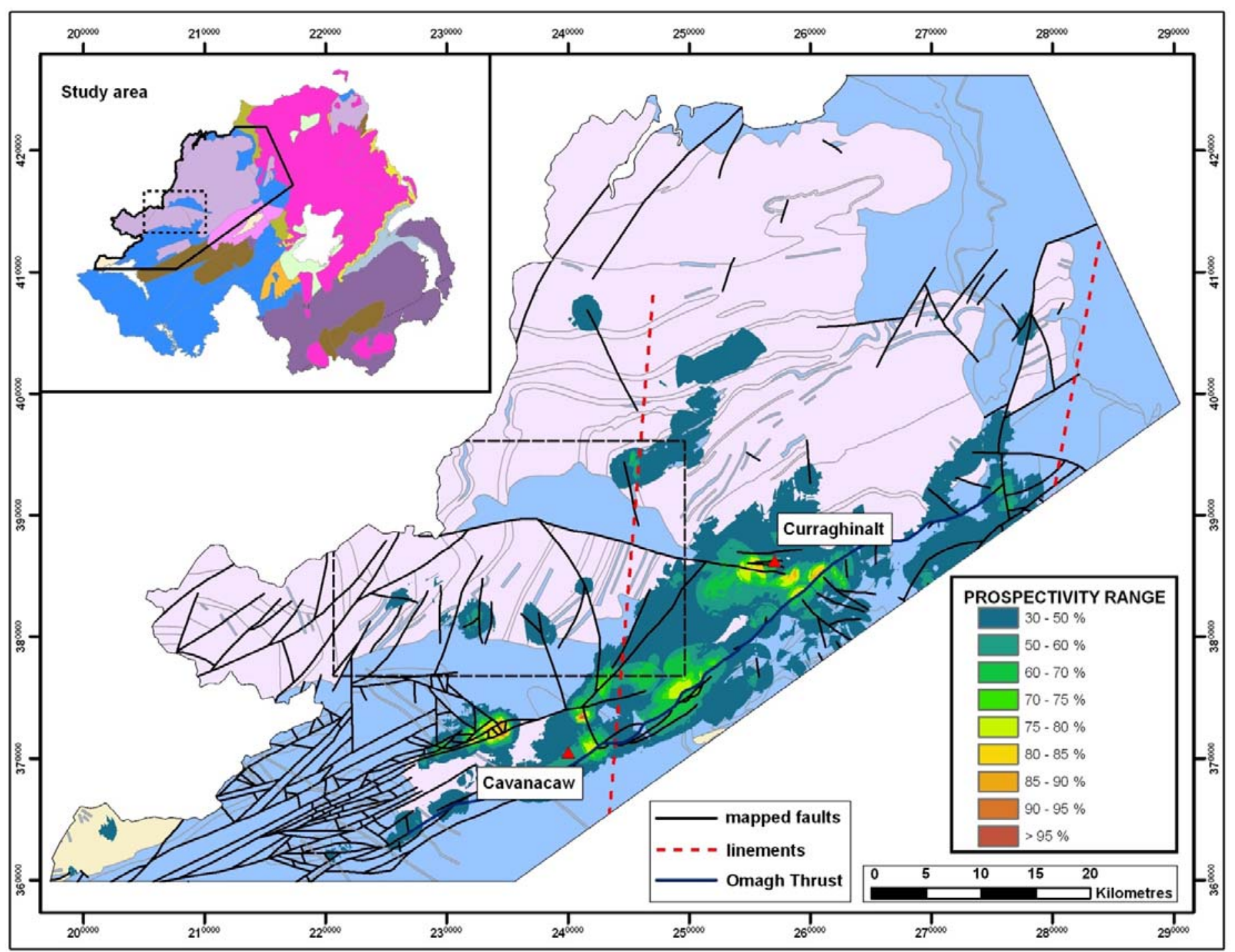

Figure 36 Cavanacaw model regional prospectivity analysis results incorporating V1 geology theme. 


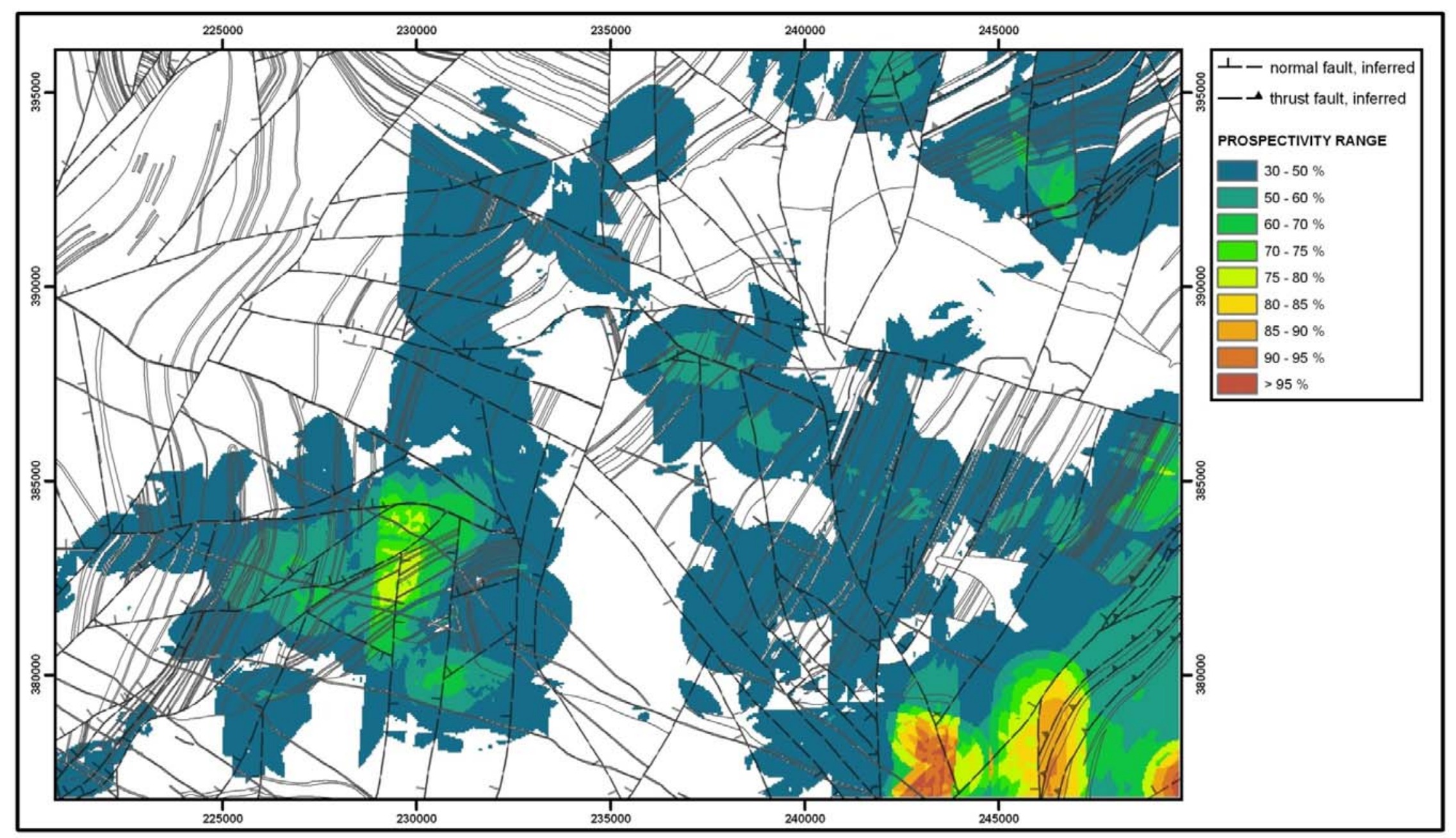

Figure 37 Curraghinalt model detailed prospectivity analysis results incorporating V1 geology theme. 


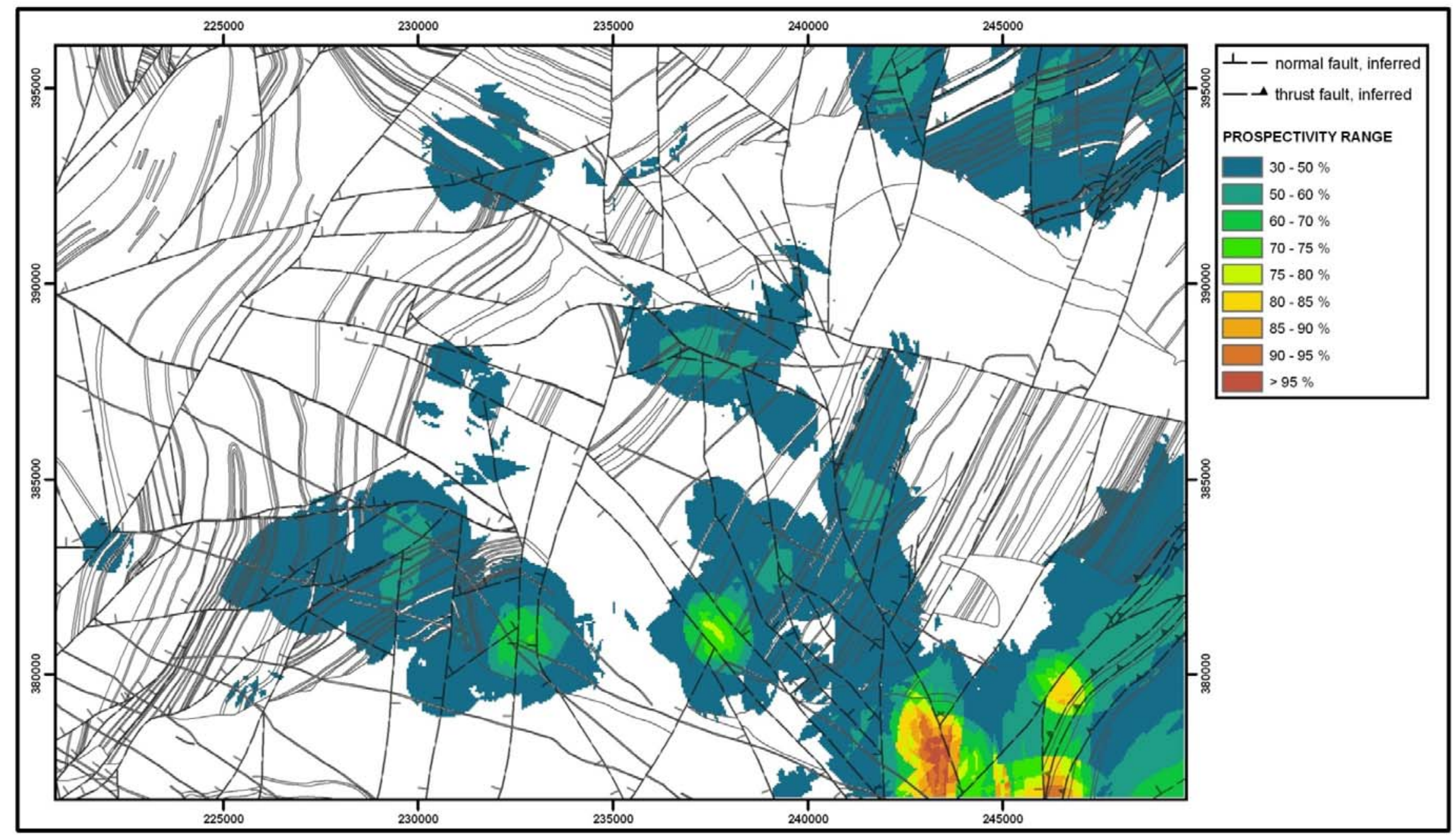

Figure 38 Cavanacaw model detailed prospectivity analysis results incorporating V1 geology theme. 


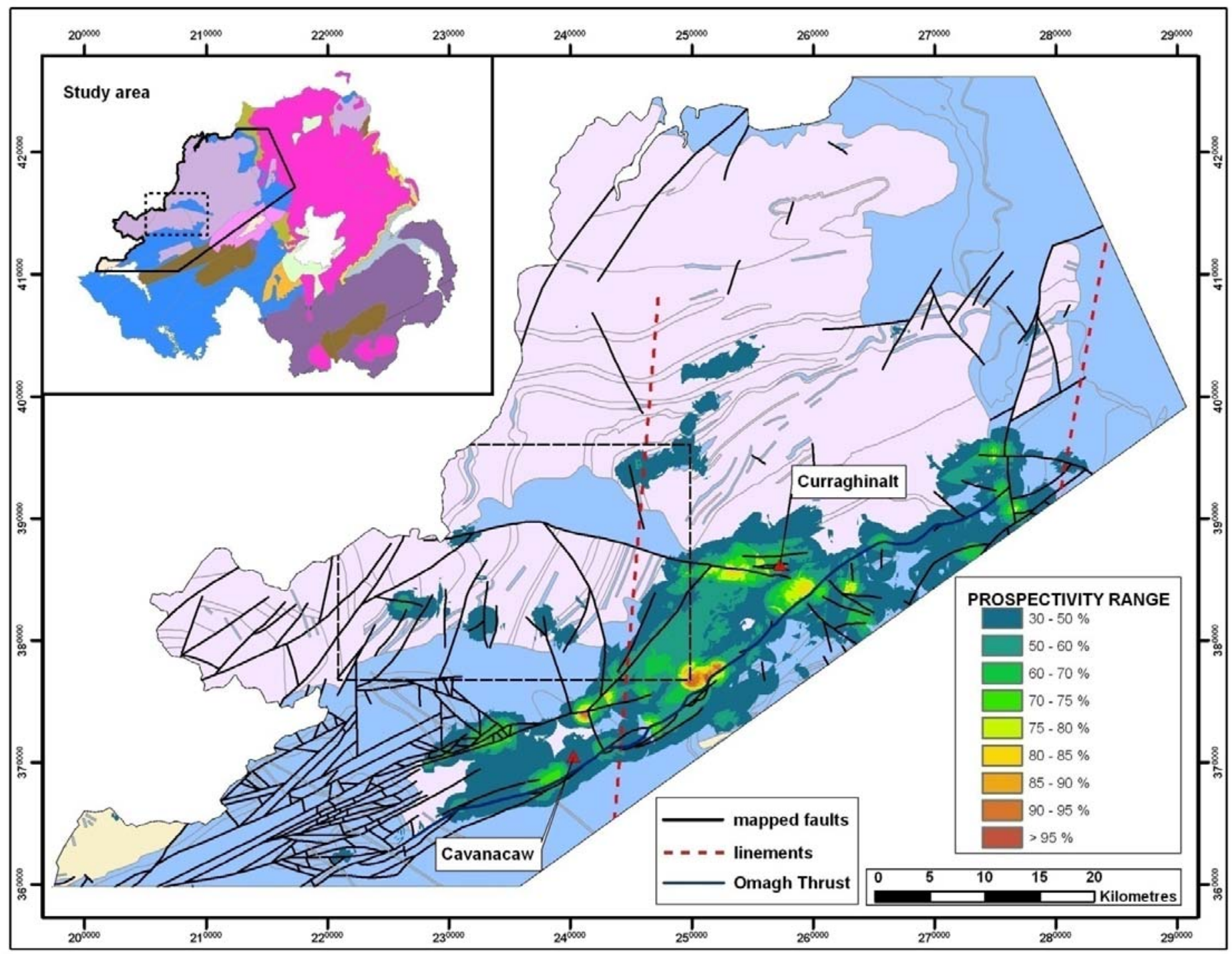

Figure 39 Curraghinalt model regional prospectivity analysis results incorporating V2 geology theme. 


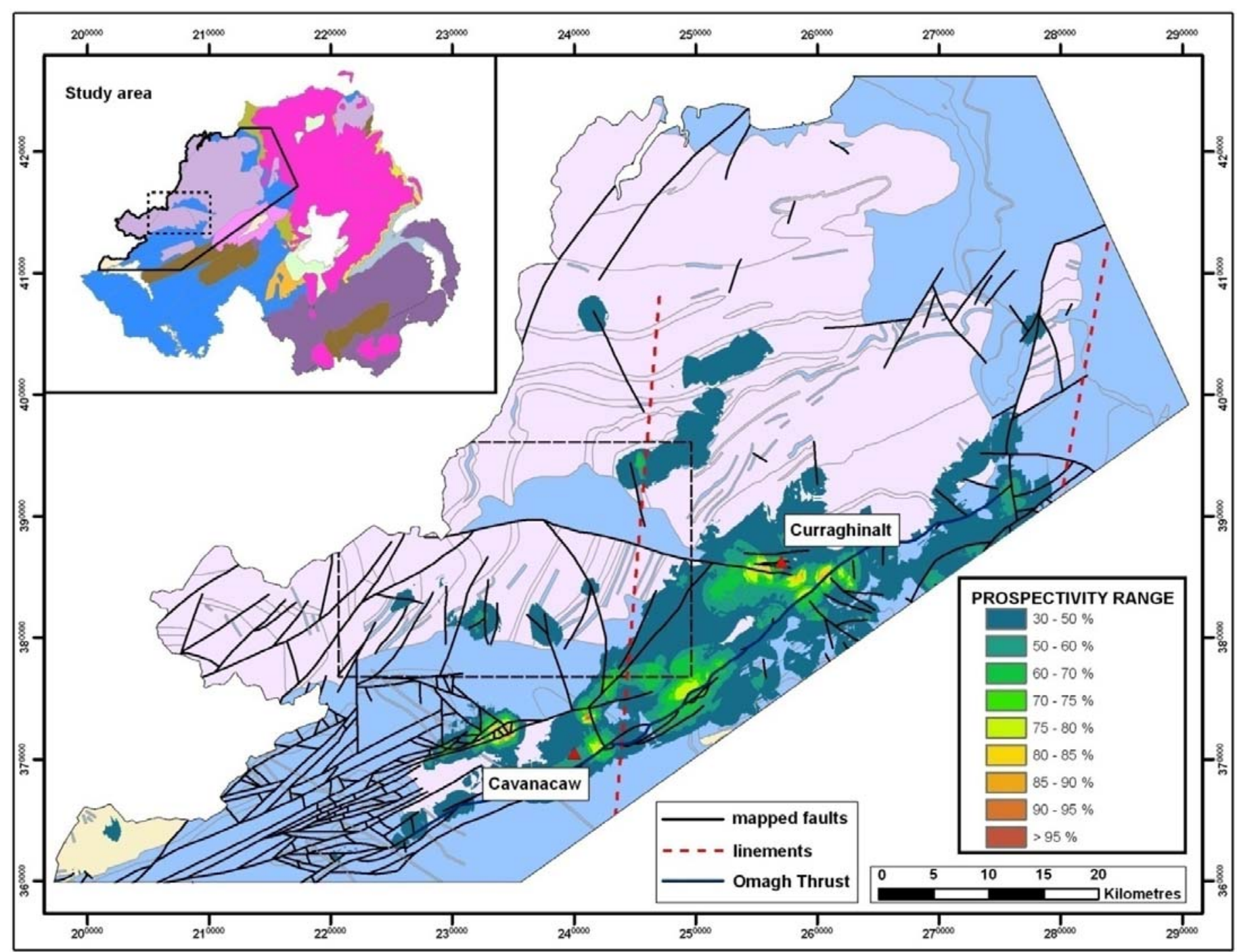

Figure 40 Cavanacaw model regional prospectivity analysis results incorporating V2 geology theme. 


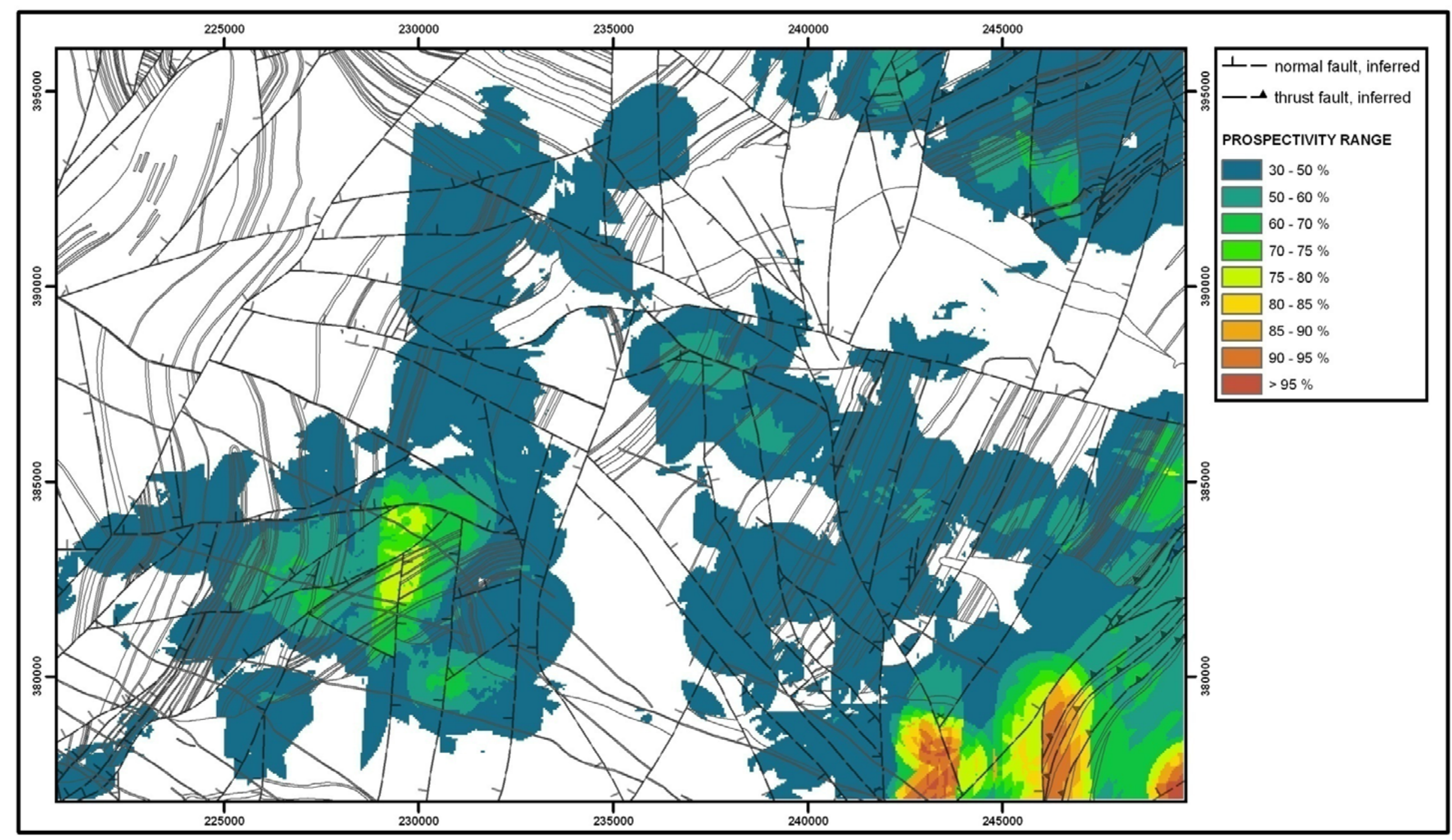

Figure 41 Curraghinalt model detailed prospectivity analysis results incorporating V2 geology theme. 


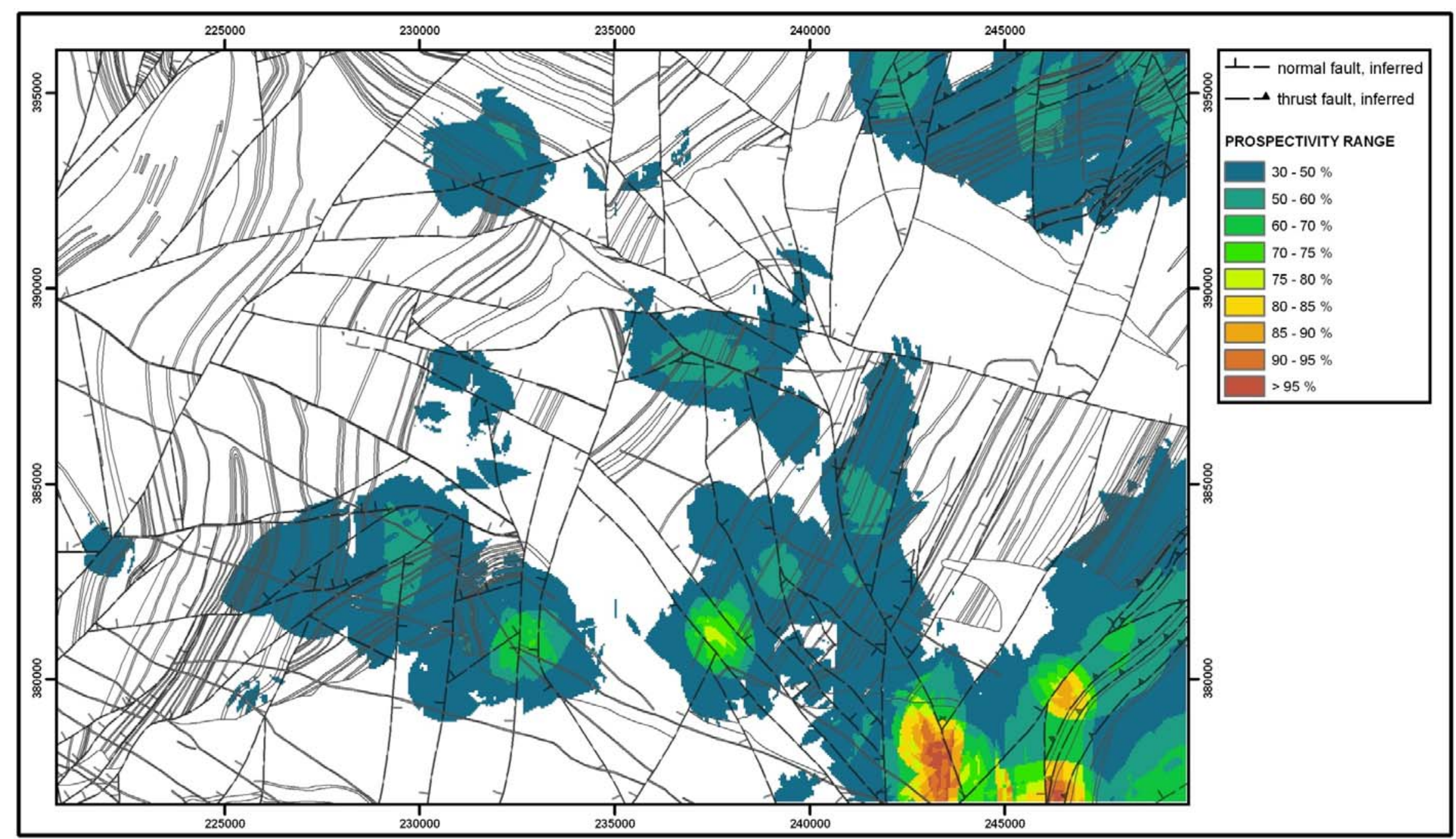

Figure 42 Cavanacaw model detailed prospectivity analysis results incorporating V2 geology theme. 


\section{Discussion and conclusions}

Prospectivity analysis over the Sperrin Mountains of Northern Ireland using a Fuzzy Logic approach and integrating new data from the Tellus geochemical and geophysical surveys has identified several areas prospective for orogenic-style gold mineralisation. Many of the targets either coincide with known occurrences of orogenic gold mineralisation or areas considered highly prospective based on previous work. In some instances the prospectivity analysis has increased the size of the target areas, while new targets have also been identified beyond the main Lack-Curraghinalt zone.

Two separate models based on deposit-scale characteristics of the Curraghinalt and Cavanacaw deposits were used in this study. A close correlation is observed between the targets generated by the two models. The Curraghinalt model defines 21 targets, 15 of which are also clear on the Cavanacaw prospectivity map. As parameterisation of the models differed in certain key parameters a greater contrast in the results might have been expected. This may suggest that the controls on the deposits are more similar than previously thought. Neither the Curraghinalt nor Cavanacaw deposits coincide with the areas of maximum prospectivity generated by the modelling. This may be explained in other ways:

1. the factors controlling the location of mineralisation are not fully understood;

2. it has not been possible to accurately translate the exploration criteria into the prospectivity model;

3. the prospectivity analysis is largely based upon regional datasets, while, the models have been developed at a deposit scale.

An additional consideration is the subjective nature of Fuzzy Logic modelling. Not only is the output highly dependent on data quality and suitability, for example, the scale of the dataset, but it is also strongly dependent on expert judgement. This expert parameterisation determines the key exploration indicators based on the mineral deposit model, assigns weightings and zones and styles of influence to them, and also includes selection of the Fuzzy Logic operator used to combine the datasets.

It is not possible to conclude if one model is superior over the other for exploration in the Sperrin Mountains. The Curraghinalt model defined four targets which were not conspicuous in the Cavanacaw results, whilst the analysis based on the Cavanacaw model shows only one target not observed on the Curraghinalt map. We conclude that continued use and refinement of both models is the preferred way forward for analysis in this terrane.

Integration of a more detailed geological framework, based upon the favourability of individual Dalradian formations for hosting gold mineralisation, had a limited influence on the final prospectivity map. However, the incorporation into the modelling of additional criteria relevant to the mineralisation will in general lead to more reliable results. Consequently it is therefore recommended that variable fuzzy membership values are assigned to different Dalradian formations in future modelling.

Detailed prospectivity analysis focusing on the Newtownstewart map sheet, within the regional project area, was undertaken to establish the potential benefits of incorporating more detailed structural data into the analysis. This approach may be compared to a typical exploration programme which starts with analysis of regional datasets (e.g. 1:250 000 scale geological mapping and stream-sediments) and moves to district-scale data acquisition (e.g. based on 1:50 000 scale geological mapping) and follow-up. The addition of higher resolution structural 
data to the analysis has in this case retained both the location and intensity of the regional targets. However, areas of low prospectivity have expanded and in some cases regional targets have merged. This results from the increased structural data contributing to prospectivity in areas previously devoid of information in the regional analysis. However, it is important to note that the detailed modelling has identified new zones of prospectivity not evident in the regional analysis. Of particular note is the coincidence of the Rylagh mineralisation with a zone of very high prospectivity on the detailed maps.

Interpretation of the regional prospectivity maps has also provided some new insight into possible regional controls on the location of mineralisation and interpretation of the geology of this area:

1. Westward extension of the Curraghinalt lateral ramp: the series of targets extending from the southern side of the Newtownstewart Basin, through Golan Burn and Curraghinalt, and continuing eastwards into the Tyrone Volcanic Complex lies on a linear west-north-westtrend. These targets appear to be related to the major east-west-trending fault, bounding the southern side of the Newtownstewart Basin. Another set of targets is located to the north of the Omagh-Kesh Basin, extending along a near-linear trend oriented approximately eastwest which passes through Rylagh and the zone of maximum prospectivity identified by the modelling (target K). These linear zones of prospectivity may be related to major structural boundaries. It is important to note that a postulated westward extension of the Curraghinalt lateral ramp, generally regarded as a critical control on the location of the mineralisation at Curraghinalt, would coincide with this zone. Accordingly the fault bounding the southern side of the Newtownstewart Basin could be interpreted as the northern boundary of this structure with the southern boundary obscured by the Omagh-Kesh Basin.

2. The relationship of volcanic-hosted gold mineralisation to Dalradian structures: the gold mineralisation at Crosh coincides with the prospective zone discussed above, to the north of the Omagh-Kesh Basin. The mineralisation is volcanic-hosted but is situated in close proximity to the Omagh Thrust and the Mullaghcarn Formation. Its coincidence with this trend suggests it may be related to a Dalradian structure.

3. Extent of the prospective Glengawana Formation: a further consideration relates to the mapping of the Dalradian in the Lack-Curraghinalt zone. The Dalradian rocks associated with the two targets to the north of the Lack Inlier are mapped as the Mullaghcarn Formation. The Glengawana Formation apparent to the east and possibly obscured by the Carboniferous is not mapped in the vicinity of the Lack Inlier. A postulated extension of the Glengawana Formation, based on its relationship to the Mullaghcarn Formation in the Curraghinalt area, would coincide with these two important targets. This is significant as proximity to the Glengawana Formation is suggested to play a role in the location of mineralisation.

4. Prospectivity of the Sperrin Fold zone: fold crests are well documented as zones of dilation and space creation. Two prospectivity targets have been identified proximal to the hinge zone of the Sperrin anticline. Gold-quartz veins associated with fractures, faults, folds and openings in anticlines are typified by Bendigo-type or saddle reef style mineralisation (Windth, 1995). Much of the auriferous mineralisation in the Meguma Terrane, Nova Scotia, Canada is concentrated in fold structures (Keppie et al. 2002). 


\section{Recommendations for further work}

The following additional work is recommended to refine the application of prospectivity analysis to the Dalradian rocks of north-western Northern Ireland. It is important to note that some of these steps would be labour intensive and therefore relatively expensive to implement. Careful evaluation of the potential benefits of each is required.

1. Handling of stream-sediment geochemistry might be improved by using a 'sample catchment' approach which extends the representativeness of the geochemical features of stream sediments to the whole of the upstream drainage basin (Spandoni et al. 2004).

2. The geochemical data should be normalised to bedrock to remove the influence of lithological variations on element distribution.

3. The results of the prospectivity analysis should be closely compared with the Tellus geophysical data to determine any new associations. Specifically, the geophysical data should be analysed to define the extent of the Curraghinalt lateral ramp and to determine whether there is a westward extension of this structure.

4. Additional occurrences of know bedrock gold mineralisation should be used to validate the results of the modelling. Compilation of a more comprehensive 'validation point' dataset will be required.

5. Weights of evidence (WoE) modelling could be used to quantify the spatial association between validation points and the results of the Fuzzy Logic modelling. This involves generalising the prospectivity map into a number of classes (e.g. very high, high, moderate etc) with equal intervals and measuring the distribution of the validation points across those map classes (Nykanen et al. 2008). This methodology allows quantitative description of the distribution of targets and aids ranking for follow-up work.

6. Given detailed knowledge of an adequate number of known occurrences of orogenic gold mineralisation within the target area a 'data driven' approach to the analysis, such as WoE, could be applied. The advantages of this technique include the removal of subjectivity inherent in knowledge-based methods.

7. Addition of further high-resolution datasets would improve the utility of the prospectivity analysis for follow up exploration. Inclusion of geochemical data from more detailed sampling grids and the routine use of 1:50 000, or larger, scale geology would be particularly beneficial.

8. Extend the prospectivity analysis of the Dalradian terrane to include other deposits types. The Dalradian rocks with their varied sequence of psammites, pelites and limestones are considered geologically favourable for stratabound base-metal mineralisation. The discovery of the Aberfeldy Ba-Pb-Zn deposit in the Scottish Middle Dalradian rocks (Argyll Group) illustrates the potential for sedimentary exhalative (SEDEX) deposits in rocks of this age.

9. Apply prospectivity analysis to other terranes in Northern Ireland including:

- Paleocene basalts of the Antrim Plateau (magmatic nickel-copper-platinum-group element (PGE) deposits and epithermal precious metal mineralisation)

- Southern Uplands-Longford-Down terrane (orogenic gold mineralisation)

\section{References}

Alsop, G I, and HutTON, D H W. 1993. Major southeast-directed Caledonian thrusting and folding in the Dalradian rocks of mid-Ulster: Implications for Caledonian tectonics and mid-crustal shear zones. Geological Magazine, 130(2), 233-244. 
An, P, Moon, W M and, Rencz, A. 1991. Application of fuzzy set theory for integration of geological, geophysical and remote sensing data. Canadian Journal Exploration Geophysics, 27, 1-11.

ARTHURS, J W. 1976. The geology and metalliferous mineral potential of the Sperrin Mountains area. Special Report Geological Survey of Northern Ireland.

Ash, C, and Alldrick, D. 1996. Au-quartz Veins. In: Lefebure, D V, Hõy, T (eds). Selected British Columbia Mineral Deposit Profiles, Volume 2 - Metallic Deposits. British Columbia Ministry of Employment and Investment, Open File 1996-13, 53-56.

Bierlein, F P, and Crowe, D E. 2000. Phanerozoic Orogenic Lode Gold Deposits. SEG Reviews, 13, $103-109$.

Bluck, B J, Gibbons, W and Ingham, J K. 1992. Terranes. In Cope, J C W, Ingham, J K and Rawson, P F (eds). Atlas of Palaeogeography and Lithofacies, Geological Society of London, Memoirs, 13, 1-4.

BOATE, G. 1652. Ireland's Natural History, London.

Boland, M. 1996. The Curraghinalt Gold Deposit in Co. Tyrone, Northern Ireland. In: Mineralization in the Caledonides (Abstract). Institution of Mining and Metallurgy Conference, June 1996, Edinburgh, Scotland.

BonHAM-CARTER, G F. 1994. Geographical information system for geoscientists: modelling with GIS. Pergamon, London.

Cliff, D C, and Wolfenden, M. 1992. The Lack gold deposit, Northern Ireland. In: Bowden, A A, EARLs, G, O’ConNer, P G and Pyne J F. The Irish Minerals Industry 1980-1990. Irish Association for Economic Geologists.

Clifford, J A. 1986. A note on gold mineralization in County Tyrone. In: Geology and Genesis of Mineral Deposits in Ireland. Andrew, C J, Crowe, R W A, Finlay, S, Pennell, W M and Pyne J F (eds). Irish Association for Economic Geology. Dublin. 45-48.

Clifford, J A, Earls, G A, Meldrum H, and Moore, N. Gold in the Sperrin Mountains, Northern Ireland: an exploration case history. In Bowden, EARLS, O'CONNOR and PynE (eds). The Irish Minerals Industry 1980-1990, Irish Association for Economic Geology, Dublin, 77-87, 1992.

Clifford, J A, Meldrum, A H, PArker, R T G, and Earls, G. 1990. 1980-90: A decade of gold exploration on Northern Ireland and Scotland. Transactions of the Institution of Mining and Metallurgy, 99, B133-138.

Copper, D C, Rollin, K E, Colman, T B, Davies, J R, and, Wilson, D. 2000. Potential for mesothermal gold and VMS deposits in the Lower Palaeozoic Welsh Basin. BGS Research Report RR/00/09.

Cooper, M R, Noble, S, Crowley, Q and, Henney, P. Under review. A new U-Pb age constraint for a late Caledonian intrusion suite in the north of Ireland: UK and Ireland geological relationships.

CoOper, M R, VAn Dam, C L, Young, M E, EArls, G and, Walker, A. In prep. Geological relationships of Palaeogene dyke swarms in Northern Ireland revealed by airborne magnetics.

Curtis, S F, Pattrick, R A D, Jenkin, J R T, Fallick, A E, Boyce, A J and Treagus J E. 1993. Fluid inclusion and stable isotope study of fault-related mineralization in Tyndrum area, Scotland. Transactions of the Institution of Mining and Metallurgy Section B Applied Earth Science, 102, 39-47.

EARLS, G. The Tellus Conference, conference proceedings. 2007.

Earls, G, Clifford, J A, and Meldrum, A H. 1989. The Curraghinalt Gold Deposit, County Tyrone, Northern Ireland. Transactions of the Institution of Mining and Metallurgy, 98, B50-51.

Earls, G, Hutton, D W H, McCaffrey, K, Wilkinson, J, Parnell, J, Moles, N, Carey, P, Boyce, A, Fallick, A, Boland, M, and LegG, I. 1996a. The Metallogeny Of The Curraghinalt Gold Deposit, Co. Tyrone, Northern Ireland. In: Mineralization in the Caledonides (abstract). Institution of Mining and Metallurgy Conference, June 1996, Edinburgh, Scotland.

Earls G, Hutton D W, Wilkinson J, Moles N, Parnell J, Fallick A, and Boyce, A. 1996b. The Gold Metallogeny of Northwest Northern Ireland Volume One. Geological Survey of Northern Ireland Technical Report GSNI/96/6

Flight, D M A, Christie, J L, Lister, T R, Simpson, P R, and Smith, B. 1995. Results of a Pilot Geochemical Survey, Northern Ireland. Minerals and Geochemical Surveys Division, British Geological Survey, Keyworth, Nottingham. Technical Report No. GSNI/95/6.

Geological Survey of Northern Ireland. 1995. Draperstown, Northern Ireland Sheet 26. Solid Geology. 1:50 000. (Keyworth, Nottingham: British Geological Survey.)

GeOlogical SurVey OF Northern IRELAND. 1997. Northern Ireland. Solid Geology (second edition). 1:250 000. (Keyworth, Nottingham: British Geological Survey.) 
GeOlogical Survey Of Northern IRELAnd. 1997. Northern Ireland. Solid Geology. 1:250 000. (Keyworth, Nottingham; British Geological Survey.)

Geological Survey of Northern Ireland. 2007. Dungiven, Northern Ireland Sheet 18. Solid Geology. 1:50,000. (Keyworth, Nottingham: British Geological Survey).

Geological Survey Of Northern Ireland. 2007. Newtownstewart. Northern Ireland Sheet 25. Bedrock. 1:50 000. (Keyworth, Nottingham: British Geological Survey.)

Geological Survey of Northern Ireland. 2008. Newtownstewart, Northern Ireland Sheet 25. Solid Geology. 1:50 000. (Keyworth, Nottingham: British Geological Survey.)

GeOlogical Survey of Northern Ireland. In prep. Strabane, Northern Ireland Sheet 17. Solid Geology. 1:50 000. (Keyworth, Nottingham: British Geological Survey.)

Goldfarb, R J, Groves, D I, Gardoll, S. 2001. Orogenic gold and geologic time: a global synthesis. Ore Geology Reviews, 18, 1-75.

Groves, D I, Goldfarb, R J, Knox-Robinson, C M, Ojala, J, Gardoll S, Yun G Y et al. 2000. Late kinematic timing of orogenic gold deposits and significance for computer-based exploration techniques with emphasis on the Yilgarn Block, Western Australia, Ore Geology Reviews, 17, 1-38.

Groves, D I, Goldfarb, R J, Robert, F, and Hart, C J R. 2003. Gold deposits in metamorphic belts: overview of current understanding, outstanding problems, future research, and exploration significance. Economic Geology, 98, 1-29.

Gunn, A G, Wiggans, G N, Collins, G L, Rollin, K E and CoATs, J S. 1997. Artificial Intelligence in mineral exploration and development: potential applications by SMEs in Britain. British Geological Survey Technical Report WF/97/3C.

Howe, A C A International Limited, July 2003. Geological Report and Exploration Potential.

HutTon, D H W and Alsop, G I. 1996. The Caledonian strike swing and associated lineaments in northwest Ireland and adjacent areas: sedimentation, deformation and igneous intrusion patterns. Journal of the Geological Society of London, 153, 345-360.

IXeR, R, PAtTRICK, R and Stanley, C. 1997. Geology, mineralogy and genesis of gold mineralization at Calliachar-Urlar Burn, Scotland. Transactions of the Institution of Mining and Metallurgy Section B Applied Earth Science, 106, 99-108.

Kemp, L D, Bonham-Carter, G F, Raines, G L, and Looney, C G. 2001. Arc-SDM: ArcView extension for spatial data modelling using weights of evidence, logistic regression, fuzzy logic and neural network analysis . http://ntserv.gis.nrcan.gc.ca/sdm/.

Keppie, D F, Keppie, J D and Murphy, J B. 2002. Saddle reef auriferous veins in a conical fold termination (Oldham anticline, Meguma terrane, Nova Scotia, Canada): reconciliation of structural and age data. Canadian Journal of Earth Sciences, 39(1), 53-63.

MinCON. Technical report on the Curraghinalt Property, County Tyrone, Northern Ireland. Mincon International Ltd. http://www.tournigan.com/i/pdf/20071129-Technical-Report-on-the-Curraghinalt-Property.pdf.

MitchelL, W I. 2004. The Geology of Northern Ireland Our Natural Foundation', Geological Survey of Northern Ireland.

Moles, N, Carey, P, Boyce, A, Fallick, A, Boland M, and LegG, I. 1996. The Metallogeny of the Curraghinalt gold deposit, Co. Tyrone, Northern Ireland. In: Mineralization in the Caledonides (Abstract). Institution of Mining and Metallurgy Conference, June 1996, Edinburgh, Scotland.

NesBitT, B E. 1993. Phanerozoic gold deposits in tectonically active continental margins. In: Foster, R P (ed). Gold Metallogeny and Exploration, Chapman \& Hall, London, 432.

NyKanen, V M, Groves, D I, OJala, V J, Eilu, P, and Gardoll, S J. 2008. Reconnaissance-scale conceptual fuzzy-logic prospectivity modelling for iron oxide copper-gold deposits in the northern Fennoscandian Shield, Finland.

NyKANEN, V M, and OJALA, V J. 2007. Spatial data mining techniques as mineral exploration tools: Examples from gold exploration in the northern Fennoscandian Shield, Finland. Proceedings of the Ninth Biennial SGA Meeting, Dublin, 2007.

Parnell, J, Earls, G, Wilkinson, J J, Hutton, D H W, Boyce, A J, Fallick, A E, Ellam, R M, Gleeson, S A, Moles, N R, CAREY, P F, and LEgG, I. 2000. Regional Fluid Flow and Gold Mineralization in the Dalradian of the Sperrin Mountains, Northern Ireland. Economic Geology, 95, 1389-1416. 
Parnell, J, Earls, G, Wilkinson, J J, Hutton, D H W, Boyce, A J, Fallick, A E, Ellam, R M, GleEson, S A, Moles, N R, CARey, P F, LegG, I. 2000. Regional Fluid Flow and Gold Mineralization in the Dalradian of the Sperrin Mountains, Northern Ireland. Economic Geology, 95, 1389-1416.

Ridely, J R, and Diamond, L W. 2000. Fluid Chemistry of Orogenic Lode Gold Deposits and Implication for Genetic Models. Review of Economic Geology, 13, 141-162.

SOPER, N J. 1994. Neoproterozoic sedimentation on the northeast margin of Laurentia and the opening of Iaeptus. Geological Magazine, 131, 291-299.

Spandoni, M, Carvarretta, and G, PAtera, A. 2004. Cartographic techniques for mapping the geochemical data of stream sediments: the "Sample Catchment Basin” approach. Environmental Geology, 45, 593-599.

STEED, G M, MoRris, J H. 1986. Gold mineralization in Ordovician greywackes at Clontibret, Ireland. In: KEPPIE, J D, Boyle, R W, Haynes, S J (eds). Turbidite-hosted gold deposits. Geological Association of Canada Special Paper, 32, 67-86.

STEPhenson, D, and Gould, D. 1995. British regional geology: the Grampian Highlands (4th edition). (London: HMSO for the British Geological Survey.)

Strachan, R A, Smith, M, Harris, A L, and FetTes, D J. 2002. The Northern Highland and Grampian terranes. In: TREWIN, N H (ed). The Geology of Scotland. The Geological Society, London, 81-148.

Thompson, S J, Shine, C H, Copper C, Halls C, and Zhao, R. 1992. Shear-hosted gold mineralisation in Co. Mayo, Ireland. In: Bowden, A A, EARLs, G, O’Connor, P G, Pyne, J F (eds). The Irish Minerals Industry 19801990. Irish Assoc Econ Geol, pp 39-49.

WANG, H, CAI, G, and ChEnG, Q. 2002. Data integration using eights of evidence model: applications in mapping mineral resource potentials. Symposium on Geospatial Theory, Processing and Applications.

Wilkinson, J J, BoyCE, A J, EARLs, G, and FalLiCK, A E. 1999. Gold remobilization by low-temperature brines: evidence from the Curraghinalt gold deposit, Northern Ireland. Economic Geology, 94, 289-296.

Wilkinson, J J, and Johnston, J D. 1996. Pressure fluctuations, phase separation, and gold precipitation during seismic fracture propagation. Geology, 24, 395-398.

WinDTH, J. 1995. Saddle reef and related gold mineralization, Hill End gold field, Australia: evolution of an auriferous vein system during progressive deformation. Economic Geology, 90, 1764-1775. 